\title{
BARREIRAS COMERCIAIS SOBRE OS PRODUTOS AGROINDUSTRIAIS BRASILEIROS NA UNIÃO EUROPÉIA
}

\author{
Rogério Edivaldo Freitas
}

\begin{abstract}
Tese apresentada à Escola Superior de Agricultura "Luiz de Queiroz", Universidade de São Paulo, para obtenção do título de Doutor em Ciências, Área de Concentração: Economia Aplicada.
\end{abstract}

P I R A C I C A B A

Estado de São Paulo - Brasil

Abril - 2004 


\section{BARREIRAS COMERCIAIS SOBRE OS PRODUTOS AGROINDUSTRIAIS BRASILEIROS NA UNIÃO EUROPÉIA}

\section{Rogério Edivaldo Freitas}

Bacharel em Ciências Econômicas

Orientador: Prof. Dr. MARCOS SAWAYA JANK

Tese apresentada à Escola Superior de Agricultura "Luiz de Queiroz", Universidade de São Paulo, para obtenção do título de Doutor em Ciências, Área de Concentração: Economia Aplicada.

P I R A C I C A B A

Estado de São Paulo - Brasil

Abril - 2004 


\section{Dados Internacionais de Catalogação na Publicação (CIP) DIVISÃO DE BIBLIOTECA E DOCUMENTAÇÃO - ESALQ/USP}

\section{Freitas, Rogério Edivaldo}

Barreiras comerciais sobre os produtos agroindustriais brasileiros na União

Européia / Rogério Edivaldo Freitas. - - Piracicaba, 2004.

$155 \mathrm{p}$.

Tese (doutorado) - - Escola Superior de Agricultura Luiz de Queiroz, 2004.

Bibliografia.

1. Barreira comercial 2. Indústria agrícola 3. Produto agrícola 4. União Européia I. Título

CDD 338.17

"Permitida a cópia total ou parcial deste documento, desde que citada a fonte - O autor" 
À Edivaldo Antônio de Freitas e à Lurdes de Oliveira Freitas dedico este trabalho, pelo que não alcanço expressar em palavras. 


\section{AGRADECIMENTOS ${ }^{1}$}

Agradeço em primeiro lugar ao Criador, que sempre me concedeu tantas oportunidades. Espero ser capaz de devolver ao mundo tudo o que Ele tem me dado.

Esse trabalho eu ofereço aos meus pais, Edivaldo e Lurdes, que me trouxeram até aqui, muito além do ponto que jamais imaginei. Muito obrigado por existirem e por terem tido a paciência de me conduzir.

Registro um agradecimento especial aos Profs. Drs. Marcos Sawaya Jank, Joaquim Bento de Souza Ferreira Filho e Geraldo Sant'Ana de Camargo Barros. São pessoas que me ensinaram muito, muito mais do que aquilo que se pode aprender em uma sala de aula.

Agradeço também ao meu irmão Ronald e à minha irmã Denise, por terem "quebrado tudo" (como dizem os bateristas) quando precisei. Valeu irmão! Valeu irmã!

A empreitada que esse trabalhou representou para mim teria sido impossível sem os conhecimentos de outros dois pesquisadores. Refiro-me aos senhores André Meloni Nassar (Dr. Kdorna) do Icone e Silvio Massaru Ichihara do Cepea. A ambos registro meu sincero Obrigado!

É preciso também agradecer a quatro pessoas que foram um suporte enorme nesse período de pesquisas e permanência em Piracicaba: o Fábio Luis Anastácio, a Dona. Toshie San, o Prof. Dr. Walter R. Accorsi, e o Vanderlei Santos da Embrapa Cruz

\footnotetext{
1 “O real não está no começo nem no fim, mas na travessia”. (Rosa, 2001)
} 
das Almas (BA). Essas pessoas foram um apoio grande em muitos momentos, embora talvez elas nem suspeitem disso.

Não posso deixar de registrar algumas figuras camaradas do Departamento com as quais partilhei boas risadas: Patrick, Henrique Grotóxo, Bel, Vítor Apache, Roberta Castro, Cinthia, Daniel Mifunga, e Étienne. Agradeço-lhes sinceramente o convívio nesses últimos anos de minha vida.

Aos músicos Paulo Eduardo de Oliveira (guitar) e Sandro Haick (drums), pelo exemplo e motivação desde longa data.

Um obrigado grande também à Maielli, que se dedica de verdade ao seu trabalho no Departamento.

À Capes, agradeço o apoio financeiro, que me permitiu inclusive fazer disciplinas em outras unidades da USP. 


\section{SUMÁRIO}

Página

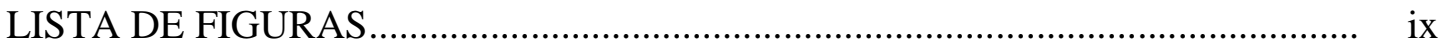

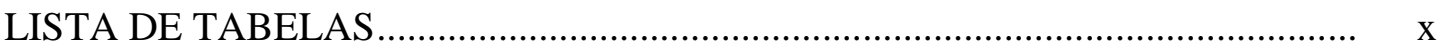

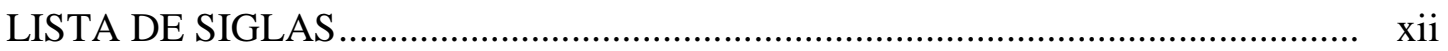

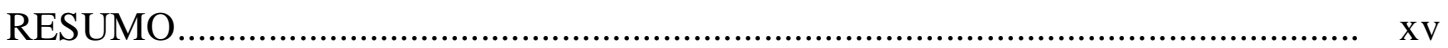

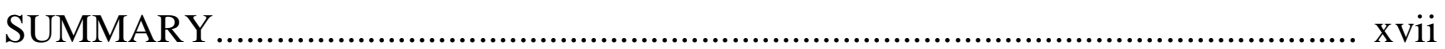

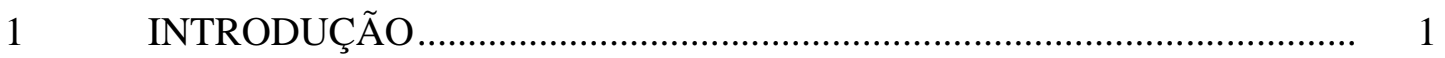

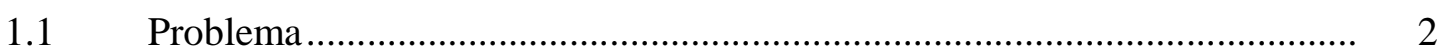

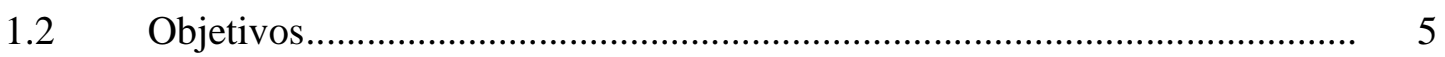

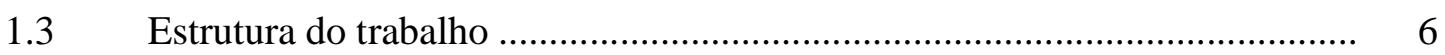

2 A POLÍTICA COMERCIAL AGRÍCOLA DA UNIÃO EUROPÉIA. ........ 7

2.1 Papel da agricultura na economia da União Européia................................... 7

2.2 A Política Agrícola Comum (PAC) …....................................................... 11

2.2.1 A economia política na PAC …............................................................... 16

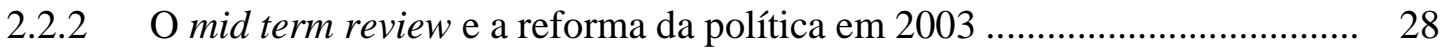

2.3 A PAC no quadro institucional da UE ...................................................... 32

2.3.1 Interfaces da PAC com a política comercial agrícola da UE. ...................... 34

2.3.2 Impactos da PAC e das tarifas agrícolas da UE .......................................... 37

2.4 A política comercial agrícola da União Européia.......................................... 41

2.4.1 Tarifa Externa Comum (TEC) ............................................................... 41

2.4.2 Medições da pauta tarifária agrícola sofrida pelo Brasil na UE .................... 44

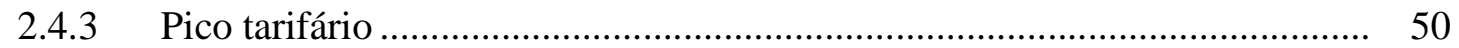

2.4.5 Tarifas sazonais e sistema de preços de entrada.......................................... 53

2.4.6 Mecanismo de gatilhos ........................................................................... 55 


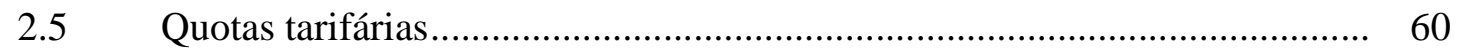

2.5.1 A economia política das quotas tarifárias ................................................. 61

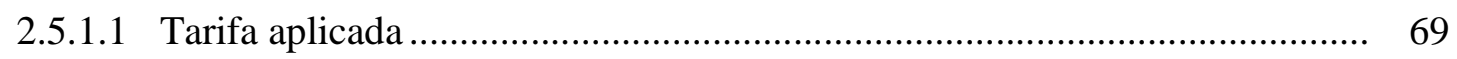

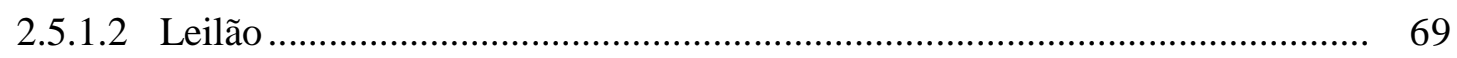

2.5.1.3 Licença sob demanda.................................................................... $\quad 70$

2.5.1.4 Primeiro a chegar, primeiro a servir-se ................................................ 71

2.5.1.5 Alocação com base em fornecimento histórico ......................................... 72

2.5.1.6 Quotas alocadas a monopólios estatais de comércio ou a grupos de produtores nacionais .................................................................... 72

2.5.2 Características específicas do regime de quotas tarifárias............................ 73

2.5.3 As quotas tarifárias dos produtos agrícolas na União Européia .................... 75

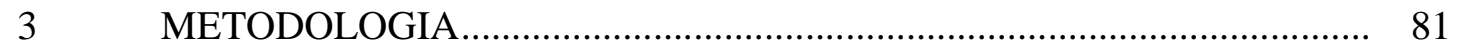

3.1 Tarifas ad valorem, específicas e EAV's ................................................ 82

3.1.1 Tarifas equivalentes ad valorem .......................................................... 83

3.1.2 Tarifas sazonais e sistema de preços de entrada......................................... 87

3.2 Estatísticas de mensuração ...................................................................... 87

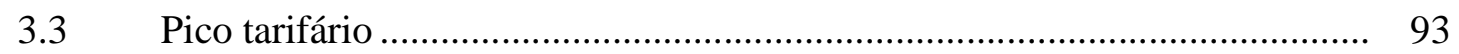

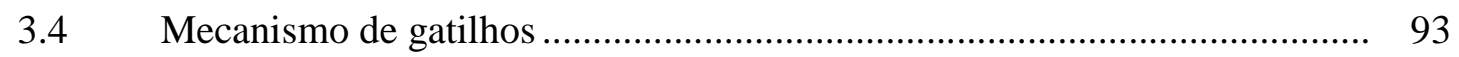

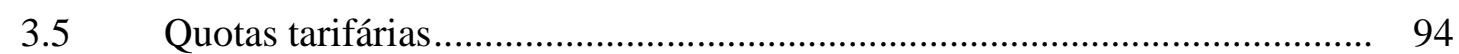

3.6 Duas propostas originais de contribuição ................................................... 94

3.6.1 Indicador de Concentração por Capítulo (ICC) .......................................... 95

3.6.2 Indicador de tarifa extraquota (ITEQ) .................................................. 96

Estimativas de suporte ..................................................................... 98

3.8 Oferta agrícola da UE ao Mercosul ...................................................... 100

3.9 Política agrícola versus proteção tarifária ................................................ 101

3.10 Bases de dados................................................................................. 102

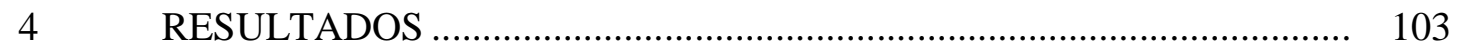

4.1 Tarifas EAV por estatísticas básicas ........................................................ 104

4.2 Tarifas sazonais e preços de entrada........................................................ 114

4.3 Teste de qui quadrado .................................................................... 116 
4.4 Indicador de Concentração por Capítulo ................................................... 119

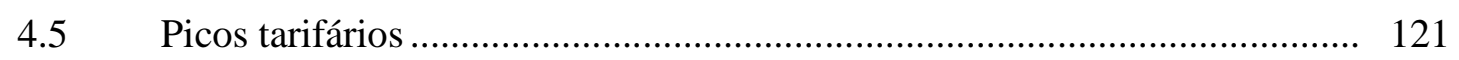

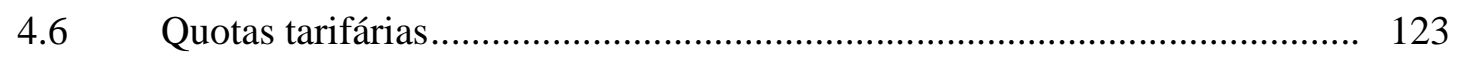

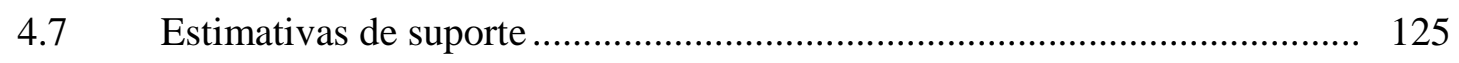

4.8 Oferta agrícola da UE .................................................................... 127

4.9 Proteção conjunta. ........................................................................... 129

5 CONCLUSÕES E RECOMENDAÇÕES DE POLÍTICA ........................ 132

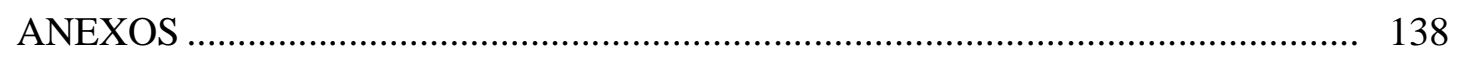

REFERÊNCIAS BIBLIOGRÁFICAS _.......................................................... 148 


\section{LISTA DE FIGURAS}

Página

1 Participação das exportações agrícolas Brasileira para a União Européia........... 1

2 Participação da UE nas importações agrícolas mundiais. ..................................... 9

3 Participação da UE nas exportações agrícolas mundiais....................................... 9

4 Agricultores comunitários por tamanho de propriedade e suporte recebido via PAC.

5 Preço doméstico sustentado via PAC e via tarifas. ............................................. 36

6 Tarifa específica sob sazonalidade.............................................................. 55

7 Formação da curva ED. ........................................................................... 66

8 Quotas tarifárias afetando demanda por importações......................................... 67

9 Grau de dependência $x$ grau de influência de variáveis. ..................................... 90

10 Hierarquia de proteção tarifária frente à pauta. ..................................................... 91

11 Valores esperados para o cálculo do coeficiente de contingência........................ 92

12 Discriminação relativa de produtos agrícolas na pauta tarifária da UE. ............. 113

13 Produtos com maior participação de tarifas pico................................................ 123 


\section{LISTA DE TABELAS}

Página

1 Projeção do balanço de produção da UE para itens selecionados (média 2004 a 2009).

2 Orçamento da PAC em 2001 (em euros milhão)

3 Participação (\%) das atividades nos gastos do Feoga.

4 Coeficiente nominal de suporte ao produtor em itens selecionados.

5 Taxa de mobilização das organizações agrícolas em países chave da UE.

6 Mudança estimada no produto, exportações e importações da UE em função da PAC.

7 Queda estimada de produção e exportação dos países latino-americanos em função da PAC.

8 Tarifa média simples da UE (\%) de acordo com Bureau (2002).

9 Tarifa média ponderada da UE em produtos agrícolas de acordo com Bouët (2003).

10 Tarifa média da UE para produtos agrícolas de acordo com WTO (2002b)...... 48

11 Tarifas médias da UE para produtos agrícolas de acordo com Castilho (2000)..

12 Picos tarifários para os maiores mercados agrícolas.

13 Megatarifas registradas na pauta agrícola consolidada da UE no conceito NMF.

14 Gatilho de volume.

15 Gatilho de preço.

16 Produtos definidos no Acordo Agrícola.

17 Tarifas compostas e EAV. 
18 Estatísticas tarifárias utilizando-se os preços das exportações mundiais (19992001)

19 Estatísticas tarifárias utilizando-se os preços das importações da UE (2000).... 107

20 Estatísticas tarifárias com os preços das exportações Brasileiras totais (janeiro a outubro de 2003).

21 Ajuste das estatísticas tarifárias com os preços das exportações Brasileiras totais.

22 Alíneas identificadas com tarifação sazonal e/ou preço de entrada.

23 Valores observados da distribuição tarifária.

24 Valores esperados da distribuição tarifária.

25 Indicador de concentração por capítulo.

26 Picos tarifários entre os capítulos agrícolas.

27 Indicador de tarifa extraquota (ITEQ).

28 Extraquota positiva e intraquota nula.

29 Resultados de mensuração das estimativas de suporte.

30 Participação dos grupos de produtos nos anexos D e E.

31 Proteção conjunta por diversos instrumentos 


\section{LISTA DE SIGLAS}

ACP

ALCA

AMAD

CIF

CNS

COMTRADE

COPA

EAV

EUROSTAT

FAO

FEOGA

FOB

GATT

GRUPO DE CAIRNS = Grupo de países exportadores agrícolas que apóia a liberalização mundial do comércio desses produtos. Seus principais membros originais foram Brasil, Austrália, Nova Zelândia e Argentina.

GTAP

$=$ Países da África, Caribe e Pacífico, ligados à UE pelos Acordos de Lomé e Cotonou.

$=$ Área de Livre Comércio das Américas.

= Base de dados Agricultural Market Access Database, organizada pela Unctad.

$=$ Sigla inglesa para custos de seguro e fretes.

$=$ Coeficiente nominal de suporte. Medida de suporte calculada pela OCDE.

$=$ Base de dados da Organização das Nações Unidas, que é voltada às estatísticas de comércio.

$=$ Comitê das Organizações Profissionais Agrícolas.

$=\quad$ Tarifas Equivalentes Ad Valorem.

$=$ Agência de Estatísticas da União Européia.

= Órgão das Nações Unidas para agricultura e alimentação.

$=$ Fundo Europeu de Orientação e Garantia Agrícola.

$=\quad$ Sigla inglesa para mercadoria livre e a bordo.

$=$ General Agreement on Tariffs and Trade

= Global Trade Analysis Project. 
$=$ Grupo de países em desenvolvimento que surgiu na Rodada de Doha e assumiu proposta mais ambiciosa de liberalização do comércio agrícola.

Dentre seus principais componentes citam-se Brasil, Índia, China e África do Sul.

ICC

$=$ Indicador de Concentração por Capítulo.

ICONE

$=$ Instituto de Estudos do Comércio e Negociações Internacionais.

ITEQ

$=$ Indicador de Tarifa Extraquota.

$\mathrm{NCM}$

$=$ Nomenclatura Comum do Mercosul.

NMF

$=$ Tarifa "Nação Mais Favorecida" do Sistema Gatt-OMC.

OCDE

OCM

OJEC

= Organização para a Cooperação e o Desenvolvimento Econômico.

$=$ Organização Comum de Mercado, instrumento de intervenção da PAC.

$\mathrm{OMC}$

$=$ Jornal Oficial das Comunidades Européias.

$=$ Organização Mundial do Comércio.

PAC

$=$ Política Agrícola Comum.

PMDR

$=$ Países de Menor Desenvolvimento Relativo.

SGP

SH

= Sistema Geral de Preferências para países em desenvolvimento.

$=$ Sistema Harmonizado de Classificação de Mercadorias.

SSG

= Special Safeguard Provision, indicador da existência de cláusula de salvaguardas especiais.

TARIC $=$ Tarifas Integradas das Comunidades Européias.

TE

$=$ Tarifa Específica.

TEC

TRAINS

$=$ Tarifa Externa Comum.

= Base de Dados "Trade Analysis and Information System", da Unctad.

$=$ Tariff Rate Quota ou quota tarifária. 
UE

UNCTAD
$=$ União Européia.

$=$ Conferência das Nações Unidas sobre Comércio e Desenvolvimento. 


\title{
BARREIRAS COMERCIAIS SOBRE OS PRODUTOS AGROINDUSTRIAIS BRASILEIROS NA UNIÃO EUROPÉIA
}

\author{
Autor: ROGÉRIO EDIVALDO FREITAS \\ Orientador: Prof. Dr. MARCOS SAWAYA JANK
}

\section{RESUMO}

Esta tese realizou-se com o intuito de melhor conhecer a proteção tarifária agrícola da União Européia (UE) e sua eventual associação com a Política Agrícola Comum (PAC). A hipótese implícita nesse trabalho é a de que há uma discriminação tarifária na pauta agrícola da UE; discriminação essa que estaria associada à estrutura da PAC. Nesses termos, o trabalho teve três objetivos complementares. Em primeiro lugar, buscou-se medir a magnitude das tarifas praticadas pela União Européia sobre os produtos agrícolas exportados pelo Brasil. Como segundo ponto, procurou-se identificar a existência de discriminação tarifária entre os grupos de produtos agrícolas presentes na pauta de tarifas do bloco europeu. E, por fim, avaliou-se a eventual existência de simultaneidade entre a proteção tarifária e as políticas domésticas de suporte à agricultura comunitária. A teoria visitada e os trabalhos já realizados com tal pano de fundo sugeriram que há grupos de produtos particularmente protegidos pelas tarifas agrícolas do bloco europeu. Esses mesmos trabalhos também apontaram para o caráter de permanência das políticas de apoio à agricultura da União Européia, mesmo após as reformas da PAC em 1992 e 2000. Tais políticas não são homogêneas; antes disso, estão concentradas em determinadas atividades e perfis de produções da agricultura do bloco. A revisão teórica também foi empregada para apresentar os principais instrumentos de 
política comercial da União Européia em itens agrícolas e para discutir os conceitos inescapáveis em barreiras tarifárias: tarifas ad valorem, tarifas específicas, mecanismo de gatilhos, picos tarifários, e quotas tarifárias. Cada um desses conceitos chave em política comercial foi avaliado com base em ferramentas estatísticas específicas, procurando-se identificar os produtos eventualmente discriminados em cada caso. Em paralelo, empregaram-se regressões lineares contra o tempo a fim de avaliar se tem ocorrido queda no nível de suporte à agricultura comunitária, bem como se procedeu à identificação dos setores menos contemplados pela oferta agrícola feita pela União Européia nas negociações do fórum biregional UE-Mercosul. Como resultado do esforço empreendido, esse texto pretende deixar duas contribuições. Primeiramente, através de simulações acerca do uso de diferentes preços de referência para a conversão das tarifas específicas e mistas em tarifas equivalentes ad valorem, no contexto da pauta agrícola comunitária. A discussão acerca dos impactos do uso de distintos preços de referência em situações similares pretende ser uma das contribuições do trabalho. Em segundo lugar, propõem-se indicadores especificamente projetados para a avaliação de duas questões importantes em acesso a mercado de bens agrícolas nos países desenvolvidos. $\mathrm{O}$ primeiro deles destinado à leitura da proteção concedida pelo mecanismo de quotas tarifárias, e o outro voltado à identificação de picos tarifários entre grupos de produtos. As conclusões do trabalho apontam para determinados grupos de produtos agrícolas alvo de proteção da parte dos instrumentos de política comercial na União Européia, destacando-se: carnes e miudezas, leite e laticínios, cereais, preparações de carne e peixes, açúcares e confeitaria, preparações de cereais, e tabaco e seus manufaturados. Esses grupos de produtos mostraram-se muito similares às produções agrícolas mais intensamente apoiadas pelas políticas de financiamento da PAC. 


\title{
EUROPEAN UNION TRADE BARRIERS ON BRAZILIAN AGRICULTURAL PRODUCTS
}

\author{
Author: ROGÉRIO EDIVALDO FREITAS
}

Adviser: Prof. Dr. MARCOS SAWAYA JANK

\section{SUMMARY}

This thesis has been done to better understand the European Union (EU) agricultural tariff protection and its association with the Common Agricultural Policy (CAP). The hypothesis is that there is tariff discrimination in the EU agricultural tariff schedule and that such discrimination is connected with the CAP structure. For this purpose, the study is oriented by three goals, which complement themselves. First, it aims to measure the magnitude of the tariff used by the European Union on the agricultural products exported from Brazil. Second, it tries to identify the existence of tariff discrimination among the groups of agricultural products in the European tariff set. At last, it evaluates the existence of simultaneity between tariff protection and agricultural support policies in the EU. Theoretical and empirical studies have already suggested that there are groups of products particularly protected by the EU agricultural tariffs. These studies also pointed to the permanent character of the agricultural support policies in the EU, even after the CAP reforms in 1992 and 2000. These policies are not homogeneous; but instead, they are shaped according to certain activities and production profiles of the EU agricultural sector. The literature has also been used to present the main instruments of the EU trade policy on agricultural goods and to discuss the key concepts on tariff barriers: ad valorem tariffs, specific tariffs, trigger tools, tariff peaks, 
and tariff-rate quotas. With the purpose of identifying the products discriminated, each of the topics on trade policy is evaluated through the application of specific statistical tools. In order to evaluate if there has been a decrease in the level of agricultural support in the European Union we use linear time series regressions. At the same time, the sectors discriminated by the EU agricultural offer in the European Union-Mercosur negotiations are also identified. The collected data are compared to evaluate the agricultural products that are protected by the EU. The present work has two main contributions. Firstly, the discussion related to the effects of using different prices to the conversion of EU specific and composed tariffs into equivalent ad valorem tariffs. Secondly, tools specially designed to analyze two important questions on agricultural market access in developed countries are proposed. The first one focuses on capturing the protection given by tariff-rate quotas, and the other focuses on the identification of tariff peaks among sets of products. The conclusions of this study point to certain sets of agricultural products targeted by the EU trade policy, especially meat, dairy products, cereals, meat preparations, sugar, cereal preparations, and tobacco. These sets of products appeared to be quite similar to the agricultural products severely supported by CAP financing policies. 


\section{INTRODUÇÃO}

A maior participação do Brasil no mercado exportador agrícola mundial é um dos elementos ainda por construir na relação do país para com seus principais parceiros comerciais. No que tange à União Européia essa maior participação depende da redução das restrições de acesso ao mercado comunitário.

A figura a seguir ilustra a importância relativa das exportações do comércio agrícola Brasileiro à União Européia, observando-se os produtos definidos no Acordo Agrícola da Rodada do Uruguai.

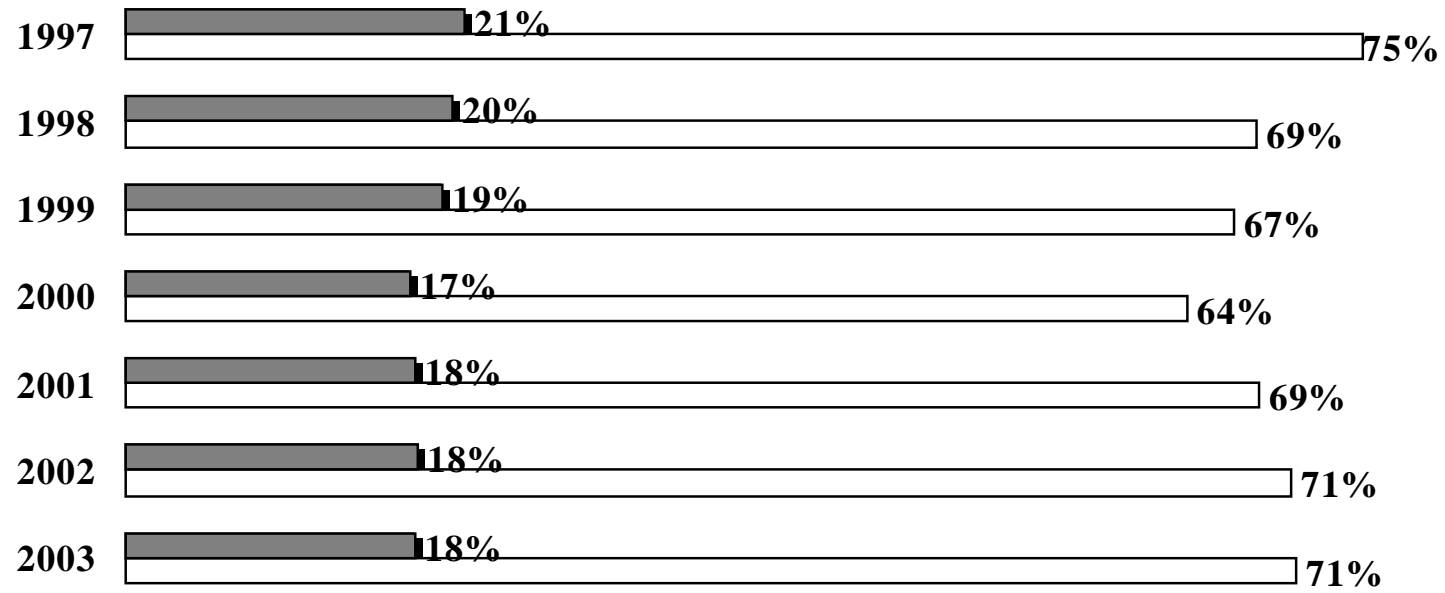

$\square$ Br-UE Agrícola/Br-UE Total

$\square$ Br-UE Agrícola/Br-Mundo

Figura 1 - Participação das exportações agrícolas Brasileiras para a União Européia.

Fonte: elaborado pelo autor a partir do Sistema Alice. 
Segundo Comissão Européia (2004), o Brasil representa tanto uma importante fonte de importações comunitárias como a espinha dorsal das futuras relações comerciais entre Mercosul e União Européia. Assim, é certo que o melhor entendimento das barreiras tarifárias impostas às exportações Brasileiras para aquele mercado torna-se necessário de forma que melhores resultados possam ser trabalhados no processo de negociação birregional Mercosul-União Européia e na própria Organização Mundial do Comércio (OMC).

Tais considerações formam o pano de fundo que contém os elementos motivadores do presente trabalho.

\subsection{Problema}

A União Européia conta hoje com 320 milhões de cidadãos sendo o maior mercado comum existente. E será ainda maior quando os países candidatos do Leste e Mediterrâneo se tornarem membros comunitários.

Ao mesmo tempo, uma das prioridades da política externa Brasileira - o relacionamento com a Europa Ocidental - caracteriza-se por uma rara combinação de fundamentos, ressaltando-se o dinamismo do intercâmbio econômico e a intensidade do diálogo político.

Hoje, o Brasil toma parte em exercícios de integração comercial internacional com resultados que serão significativos para os diferentes setores produtivos do país.

No contexto multilateral, o país tem participado cada vez mais ativamente das rodadas de negociação promovidas pela $\mathrm{OMC}$, inclusive redefinindo alianças e posições quanto à demanda por maior acesso a mercados no caso de bens agrícolas. A participação Brasileira no chamado Grupo de Cairns, bem como a recente atuação ao lado de indianos e chineses sob a roupagem do G20 na Rodada de Doha mostram a centralidade econômica e política do tema. 
No nível regional, destacam-se as negociações da Área de livre comércio das Américas (ALCA) e aquelas pertinentes à integração UE-Mercosul. Embora possam ser vistas como processos reflexos entre si, elas possuem características particulares.

No caso da ALCA, tem-se uma negociação entre os países americanos, naturalmente condicionada pelos diferentes pesos econômicos e políticos das nações envolvidas. A iniciativa foi proposta em 1994, e objetiva promover a eliminação de barreiras sobre o comércio e o investimento na região, de forma gradual e progressiva, porém mantendo políticas comerciais independentes em relação a países não-membros.

Nesse front, a polarização de propostas, a amplitude de temas tratados e a pouca disposição em se estabelecerem regras claras e abrangentes têm direcionado o diálogo para o foco dos problemas e exceções, em lugar das soluções. Esses pontos têm enfraquecido os resultados e a profundidade desse processo negociador.

Paralelamente, as reuniões do fórum biregional UE-Mercosul ganham relevância à proporção em que a Alca é negociada por meio de regras de exceção. Em termos de acesso a mercados, as propostas dos lados europeu e sul-americano têm se concretizado através de ofertas cruzadas de bens sujeitos a cronogramas de desgravação tarifária. Sob esse aspecto, uma das pedras no sapato do histórico das relações entre o Brasil e a Europa unificada sempre esteve nas dificuldades quanto ao ingresso de produtos agrícolas e/ou agrícolas processados nas economias capitalistas do velho continente. É o caso recorrentemente citado dos lácteos, cereais, carnes e açúcar.

De fato, se os países da UE alegam dificuldade em acesso ao mercado Brasileiro de bens industriais, há também um problema de acesso dos produtos agrícolas e agrícolas processados Brasileiros ao mercado consumidor da UE.

Concomitantemente a todo esse processo, o Brasil mostrou-se ao longo de sua formação econômica e social um país dotado de vantagem comparativa na produção de itens agrícolas e/ou agrícolas processados. Assim, o país assumiu ou desenvolveu 
reconhecida vantagem comparativa em produtos como café, carnes, tabaco, açúcar, soja e mesmo algumas frutas.

Ante a essas considerações, há um custo implícito elevado para o Brasil em não aprofundar esses processos negociadores. Particularmente em relação ao caso europeu esse argumento pode ser caracterizado por três aspectos fundamentais.

Por um lado, a importância relativa das exportações agrícolas Brasileiras à UE em relação às exportações totais do país. Em segundo lugar, o fato de a Europa unificada executar uma política agrícola intervencionista que lhe permite sair de uma posição de importadora líquida para exportadora líquida em termos de produtos agroindustriais. E, como terceiro ponto, o aumento do comércio agrícola intrabloco tão logo o processo de expansão da UE para Leste esteja concluído.

Além disso, a não negociação/obtenção de um acesso mais aberto ao mercado consumidor europeu nesses itens implica tornar-se recursivamente excluído do comércio mundial de commodities à medida que evoluem processos integrativos paralelos dos quais o Brasil não toma parte e nos quais seja substituído por outros ofertantes nos bens em que é competitivo.

Esse quadro realça a importância em se conhecer de forma clara as barreiras comerciais que afetam o acesso dos produtos agrícolas e agrícolas processados Brasileiros nos grandes mercados consumidores, tanto mais pelo fato de que EUA, UE, e Japão têm, em regra, desvantagem comparativa frente ao Brasil nesses bens.

Assim, as questões que motivaram esse trabalho foram duas, a citar:

Qual a magnitude da tarifa praticada pela União Européia sobre os produtos agrícolas e agrícolas processados Brasileiros?

Existe discriminação na pauta tarifária da União Européia entre os produtos agrícolas e agrícolas processados exportados pelo Brasil? 
E subsidiariamente: se essa discriminação existe, ela pode ser identificada com a Política Agrícola Comum (PAC) em alguma medida?

Da ótica do autor do presente texto, a resposta e o claro entendimento dessas questões seriam subsídios valiosos no processo negociador dos acordos de integração de que o Brasil toma parte nesse momento.

\subsection{Objetivos}

Os objetivos primários e secundários do presente trabalho são:

I) Medir a pauta tarifária da União Européia incidente sobre os produtos agrícolas exportados pelo Brasil, desagregável em dois tópicos:

i. elaborar um mapeamento, procurando identificar os seguintes mecanismos de restrição ao acesso: tarifas específicas, tarifas sazonais, mecanismo de gatilhos, picos tarifários, e estrutura das quotas tarifárias;

ii. calcular determinados indicadores estatísticos de proteção para produzir-se uma hierarquia dos capítulos em termos da proteção européia sobre produtos agroindustriais de interesse do Brasil;

II) Identificar os grupos de produtos agrícolas discriminados.

III) Identificar os grupos de produtos agrícolas mais afetados pelos mecanismos da Política Agrícola Comum, em particular as políticas de suporte de preços e pagamentos diretos. 


\subsection{Estrutura do trabalho}

Para tal, a estrutura do trabalho terá o seguinte encaminhamento.

No capítulo 2, desenvolve-se uma análise da política comercial agrícola da União Européia, bem como uma reflexão acerca da economia política da proteção a partir dos lobbies agrícolas europeus envolvidos.

No capítulo 3, apresentam-se os procedimentos metodológicos.

O capítulo 4 foi reservado aos resultados, incluída uma discussão acerca dos diferentes preços de referência que podem ser utilizados para a mensuração de uma estrutura tarifária agrícola como a da União Européia.

Por fim, o capítulo 5 encerra os esforços deste estudo com as respectivas conclusões. 


\section{A POLÍTICA COMERCIAL AGRÍCOLA DA UNIÃO EUROPÉIA}

\subsection{Papel da agricultura na economia da União Européia}

A partir de dados da Comissão Européia (2001), de Brasil(2001) e da UKFG (2002a) destacam-se números fundamentais acerca da importância relativa da agricultura na União Européia, ou seja:

- a atividade agrícola representa atualmente cerca de 1,8\% do PIB total da União Européia;

- mais de três quartos da área na UE são dominados pela agricultura ou por áreas de floresta;

- há cerca de sete milhões de pessoas ocupadas na produção de bens primários ${ }^{2}$, excluída a mão de obra sazonal ou temporária, o que equivale a cerca de $4,5 \%$ da População Economicamente Ativa (PEA) da Europa unificada;

- a superfície agrícola útil da UE cobre em torno de 136 milhões de hectares da área total dos países comunitários, distribuídos em cerca de sete milhões de propriedades;

- os ramos de produção econômica mais importantes em agricultura são, pela ordem, laticínios, suinocultura, carne bovina, legumes frescos, vinhos e frango;

- a União Européia é o maior importador mundial de produtos agrícolas e o segundo maior exportador, sendo os Estados Unidos, o Brasil e a Argentina seus principais fornecedores nesses itens;

\footnotetext{
${ }^{2}$ Agricultura, silvicultura, caça e pesca.
} 
- a indústria agroalimentar é o maior setor industrial na UE, contemplando cerca de 22 mil empresas que ocupam 2,6 milhões de trabalhadores.

Em nível de subsetores, as principais atividades econômicas na agricultura comunitária são:

- leite e derivados: cerca de 17,6\% da produção agrícola total em 1997;

- cereais: destacando-se o trigo, a cevada, o centeio e o milho;

- $\quad$ setor carnes (bovina, suína e de aves): em torno de 18\% da produção agrícola total;

- oleaginosas: com acentuado fluxo de importações destinadas à alimentação do rebanho local;

- frutas e legumes: respondendo por 9\% da produção agrícola total, sendo a UE um grande exportador de tomates para os mercados da Rússia e dos Estados Unidos;

- vinho: nesse bem a UE responde por $60 \%$ da produção mundial, sendo o principal exportador global.

Quanto à localização geográfica, as produções de frutas e vegetais concentram-se nos países mediterrâneos, enquanto as produções de lácteos, carnes, oleaginosas e cereais podem ser encontradas em todos os Estados Membros. Os maiores países produtores são a França, a Alemanha e o Reino Unido, seja em volumes seja em valores.

No intercâmbio comercial, há uma nítida dinâmica exportadora da agricultura comunitária. Isso é notável observando-se os níveis de participação da União Européia no comércio internacional de produtos agrícolas, conforme a seguir. 


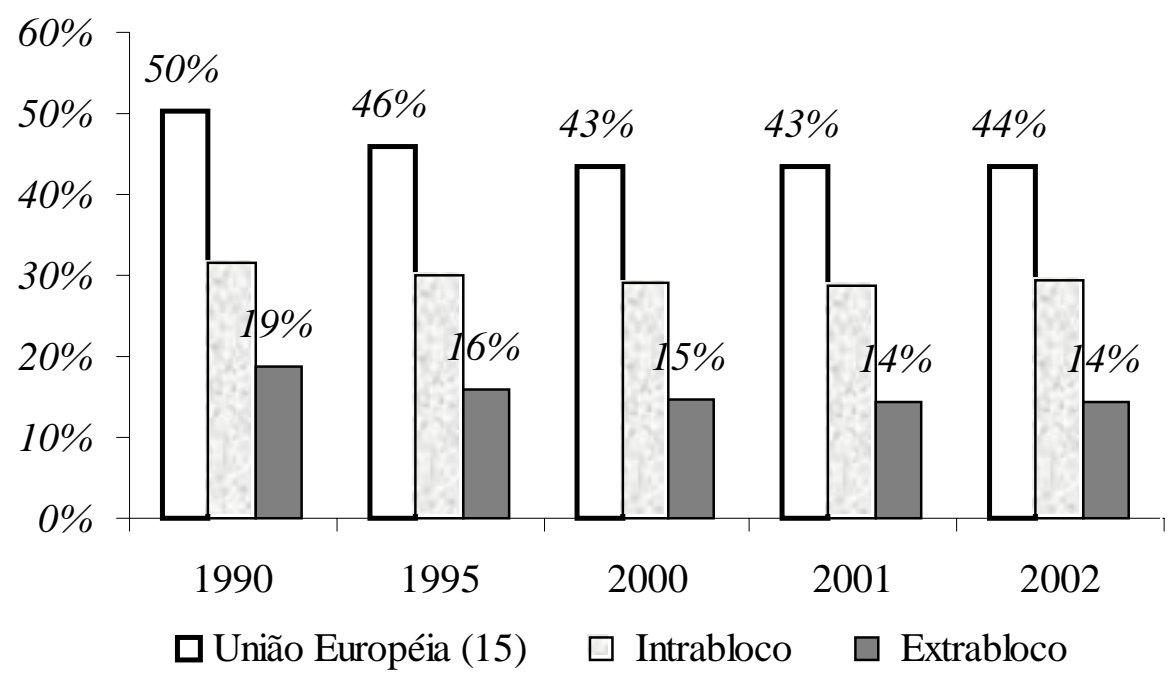

Figura 2 - Participação da UE nas importações agrícolas mundiais.

Fonte: World Trade Organization (WTO) (2004)

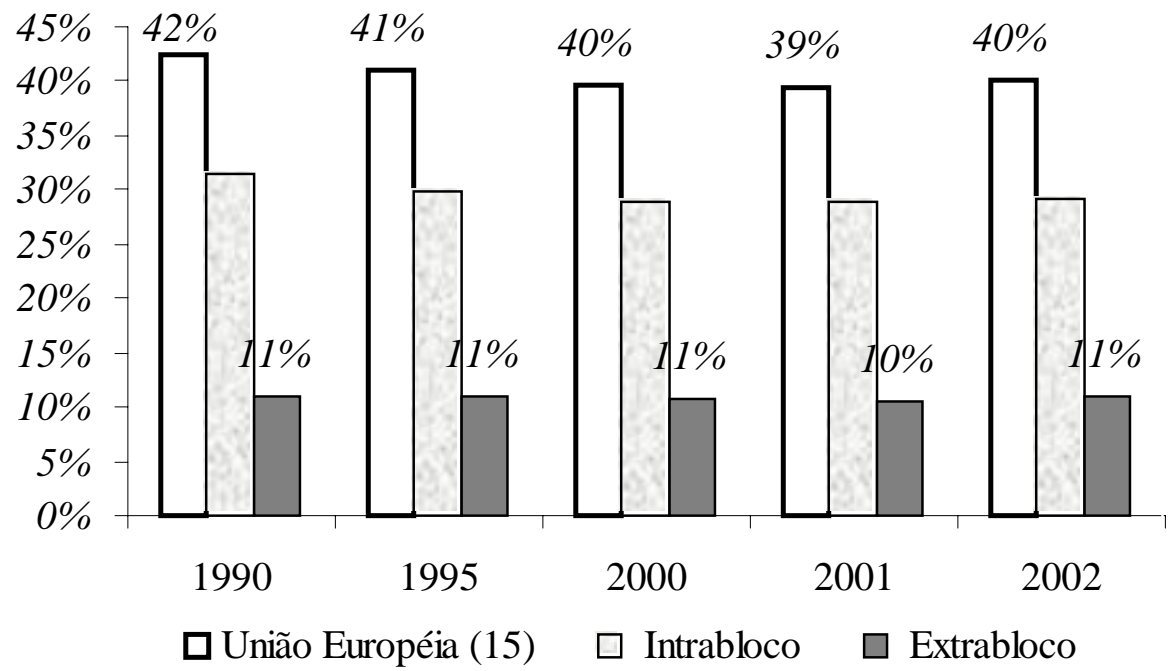

Figura 3 - Participação da UE nas exportações agrícolas mundiais.

Fonte: WTO (2004) 
Ao mesmo tempo, com base na tabela abaixo é possível observar o caráter auto-suficiente da UE em mercados agrícolas-chave como cereais, trigo, queijo, manteiga e carnes (suína, bovina e de aves).

Tabela 1. Projeção do balanço de produção da UE para itens selecionados. (média 2004 a 2009)

\begin{tabular}{lcccccc}
\hline Bem ${ }^{1}$ & Produção & Consumo & $\begin{array}{c}\text { Auto-suficiência } \\
(\%)\end{array}$ & Importações & Exportações & Superávit \\
\hline Cereais & 219,6 & 197,0 & 111 & 8,9 & 31,1 & 22,2 \\
Trigo & 111,8 & 98,6 & 113 & 5,2 & 18,4 & 13,2 \\
Arroz & 1673,7 & 2006,0 & 83 & 942,7 & 221,0 & $-721,7$ \\
Carne bovina $^{2}$ & 7666,8 & 7488,5 & 102 & 471,5 & 668,2 & 196,7 \\
Carne suína $^{2}$ & 18244,7 & 17114,7 & 107 & 79,2 & 1209,7 & 1130,5 \\
Carne de aves $^{2}$ & 9418,2 & 9155,7 & 103 & 742,5 & 1005,0 & 262,5 \\
Carne ovina $^{2}$ & 1066,8 & 1363,3 & 78 & 301,7 & 5,0 & $-296,7$ \\
Queijos & 7552,7 & 7499,3 & 101 & 181,5 & 463,8 & 282,3 \\
Manteiga & 1740,5 & 1726,5 & 101 & 174,2 & 191,7 & 17,5 \\
Leite em pó & & & & & & 160,8 \\
desnatado & 839,5 & 802,3 & 105 & 104,3 & & 56,5 \\
\hline
\end{tabular}

Fonte: Comissão Européia (2002)

1 Cereais e trigo contabilizados em milhões de toneladas, os demais bens em mil toneladas;

2 No caso das carnes, foram contabilizados os animais vivos e os já abatidos.

Em termos de parceiros de comércio, os principais mercados para as exportações agrícolas ou de processados agrícolas da UE são os Estados Unidos, a Rússia, o Japão e a Suíça, com um elevado volume de exportação de itens processados.

Numa primeira aproximação, é também preciso citar que na União Européia vigora uma conhecida política de proteção e suporte agrícolas. A chamada Política Agrícola Comum (PAC) está estruturada em órgãos de intervenção por produto de interesse e merecerá uma análise pontual levando-se em conta que a inexistência ou 
arrefecimento de seus mecanismos de controle implicam, em tese, maiores níveis de acesso ao mercado consumidor de produtos agrícolas da União Européia.

\subsection{A Política Agrícola Comum (PAC)}

Enquanto construção regional, a Política Agrícola Comum consistiu no primeiro e grande experimento de união política e econômica da Europa unificada e sua implementação e funcionamento estiveram ligados ao rápido processo de transição de uma sociedade agrária para uma economia industrial e de serviços pós Segunda Guerra Mundial.

Com tal friso, a PAC viu-se fundamentada em três princípios, quais sejam:

- o da unicidade de mercado: significando uma gradativa e crescente harmonização de políticas de comércio exterior e livre trânsito de bens intra Comunidade Econômica Européia, então o embrião da UE;

- o da solidariedade financeira: refletida num orçamento comunitário no qual as contribuições individuais são proporcionais a partir de critérios como população e PIB;

- o da preferência comunitária: protegendo-se os mercados locais contra as importações e estruturando-se sucessivamente a Tarifa Externa Comum (TEC). Para Bureau (2002) esse processo foi acompanhado pelo rápido aumento no uso de insumos químicos, especialização agrícola regional e intensificação da produção agrícola. Em paralelo, o suporte de preços como mecanismo de intervenção da PAC beneficiou principalmente os produtores maiores e gerou aumentos reais no preço e aluguel da terra.

Nos seus primórdios, a PAC era composta basicamente por um sistema de suporte de preços, por um mecanismo de controle de importações e por um fundo de co- 
financiamento da Política. Tal esqueleto foi sendo gradativamente reforçado desde o início da década de 1960. Segundo Jank et al. (2003), a manutenção dessa estrutura aliada aos avanços tecnológicos incorporados na agricultura européia produziram sucessivos aumentos da produção e dos respectivos excedentes agrícolas.

Nessa mesma linha de argumentação, de acordo com Marsch \& Tarditi (2003), nas últimas décadas a oferta de produtos agrícolas na União Européia cresceu a uma taxa média de $2 \%$ ao ano, ao passo que a demanda cresceu a uma taxa de apenas $0,5 \%$ ao ano.

Em verdade, é preciso reconhecer que a Política Agrícola Comum só foi possível enquanto pilar de consolidação da atual União Européia por conta da aceitação de uma função-chave para a agricultura européia no esforço de reorganização física, produtiva e social dos países europeus líderes pós Segunda Guerra Mundial. Esse processo, segundo Abramovay (1999), passa pela leitura de quão importante é a agricultura nas sociedades francesa e alemã nos primórdios da Comunidade. Para esse autor, nenhum país europeu foi tão longe na adoção de práticas protecionistas quanto a França e a Alemanha, seja pela estruturação de barreiras tarifárias e não tarifárias como pela criação de agências governamentais com poder monopolista sobre o comércio de cereais.

Embora reconhecendo que a completa análise da PAC merecesse um projeto de tese específico, vale a pena delinear como ela se articula, quais suas principais commodities e como ela afeta os mercados de produtos agrícolas na UE. De pronto, alguns grandes números do processo de funcionamento da PAC são destacáveis:

- cerca de 43 bilhões de euros são consumidos anualmente pela PAC, ou 45\% do orçamento da UE;

- dois terços da PAC vêem seus recursos direcionados à produção vegetal; 
- do total de recursos da PAC, cerca de $65 \%$ se transformam em pagamentos diretos aos agricultores;

- ao menos um quarto dos valores despendidos com a PAC é pago a processadores, exportadores ou outros agentes que não os produtores agrícolas comunitários;

- como políticas centrais de suporte hoje empregadas no processo de funcionamento da PAC, tem-se a fixação de preços garantidos por meio de compras de intervenção e a imposição de quotas de produção;

- embora a produção agrícola responda por algo como 2\% do Produto Nacional Bruto da Comunidade, o complexo agroindustrial como um todo responde por cerca de $6 \%$ do valor adicionado bruto total na União Européia;

- há países que absorvem, via PAC, proporcionalmente mais recursos do que as respectivas contribuições ao orçamento global da UE. A França é o caso mais notório.

Segundo USDA (2001) a PAC é uma política comunitária focada sob a administração da oferta agrícola local e manuseada para o alcance de metas internas de preços via controle da produção doméstica e controle dos preços de importação. De fato, esse mesmo estudo afirma que os preços estabelecidos em Bruxelas ainda são factíveis, pois as tarifas da Nação Mais Favorecida (NMF) ${ }^{3}$ são consideravelmente maiores que o gap entre os preços internos da UE e os preços mundiais, particularmente em itens como grãos, açúcar (de beterraba), frutas não tropicais, vegetais, vinho, carne de frango, ovos, carne suína, lácteos e carne bovina.

Gács \& Wyzan (1998), ao analisarem a transposição da PAC para os novos membros, concluem que a Política mantém os preços comunitários claramente acima

\footnotetext{
${ }^{3}$ Os países com os quais a União Européia não possui acordos comerciais preferenciais fazem face, na entrada do mercado único, à tarifa NMF, além de outras medidas tarifárias impostas pela UE. Na acepção de Deardorff (2003), trata-se do princípio fundamental para o sistema Gatt/OMC de impor igual tratamento aos parceiros comerciais. Consideradas exceções, cada país obtém a mais baixa tarifa que qualquer outro país, e as reduções de tarifa concedidas a um país são estendidas aos parceiros do sistema.
} 
dos preços mundiais, resultando em excessos de oferta sujeitos a exportações necessariamente subsidiadas.

No todo, as políticas de suporte respondem por cerca de $90 \%$ do orçamento da PAC, ao passo que os $10 \%$ restantes contemplam, grosso modo, políticas de ajustamento estrutural, administração ambiental e diversificação de culturas. Observe-se o orçamento da PAC no exercício de 2001, ressaltando-se a citada concentração de recursos nas políticas de intervenção, mesmo após as reformas de 1992 e $2000^{4}$.

Tabela 2. Orçamento da PAC em 2001. (em euros milhão)

\begin{tabular}{lcc}
\hline \multicolumn{1}{c}{ Produção } & Recursos & \% nos recursos \\
\hline Total em produtos vegetais & 27.595 & 63.7 \\
Grãos (cereais, oleaginosas, grãos para ração animal) & 18.026 & 41.6 \\
Total em produtos animais & $10.158,7$ & 23.5 \\
Carne bovina & 6.007 & 13.9 \\
Óleo de oliva & 2.473 & 5.7 \\
Leite e derivados & 2.345 & 5.4 \\
Açúcar & 1.726 & 4.0 \\
Frutas e vegetais & 1.654 & 3.8 \\
Carne caprina & 1.620 & 3.7 \\
Vinícolas & 1.153 & 2.7 \\
Gastos auxiliares & 1.049 & 2.4 \\
Fumo & 1.000 & 2.3 \\
Fibras e bicho da seda & 855 & 2.0 \\
Forrageiras e leguminosas & 384 & 0.9 \\
Outros produtos vegetais & 324 & 0.7 \\
Aves, suínos e ovos & 170 & 0.4 \\
Outros produtos de origem animal & 16.7 & 0.0 \\
Políticas de suporte - total & $38.802,7$ & 89.6 \\
Desenvolvimento rural & 4.495 & 10.4 \\
Total da PAC & $43.297,7$ & 100.0 \\
\hline
\end{tabular}

Fonte: Comissão Européia (2001a), citado em UK Food Group (UKFG) (2002a)

\footnotetext{
${ }^{4}$ De acordo com Abramovay (1999), pelos objetivos iniciais da Comunidade, a política de estruturas deveria ser contemplada com $25 \%$ dos gastos totais do Feoga, mas estes nunca chegaram nem perto disso.
} 
Ao mesmo tempo, é importante lembrar que a PAC não é uma política uniforme, mas sim um conjunto de instrumentos políticos direcionados. Por isso, seus efeitos distributivos no interior dos países membros são significativos, seja sobre a alocação e migração de fatores entre os Estados, como sobre a definição do perfil do setor agrícola (e de seus processados) na $\mathrm{UE}^{5}$.

Mesmo que a PAC responda por em torno de $45 \%$ do orçamento comunitário, conforme recorda UKFG (2002a), os valores da tabela anterior não são a conta total da PAC. Dali estão excluídas as contribuições dos Estados Membros para o co-financiamento das medidas sob o segundo pilar, variando de $25 \%$ a $75 \%$ do gasto total em cada medida, conforme as especificidades regionais.

Enquanto conjunto de políticas em operação, dois mecanismos que não podem ser esquecidos em referência à PAC são o sistema de administração de subsídios à exportação e os gastos de intervenção. Os subsídios à exportação são pagáveis tanto sobre matérias-primas agrícolas como sobre ingredientes (cereais, leite, açúcar, arroz e ovos) contidos em produtos processados (chocolate, biscoitos e bebidas alcoólicas), para todos os regimes que sustentam preços comunitários acima dos preços mundiais.

Em particular os acordos com alguns Países de Menor Desenvolvimento Relativo (PMDR) possibilitaram que quantidades de açúcar de cana fossem importadas sem tarifas, submetidas a refino interno e então exportadas como açúcar branco, fruindo de subsídios à exportação.

\footnotetext{
${ }^{5}$ UKFG (2002a) e Bureau (2002) reiteram que mesmo a distribuição de pagamentos diretos após as reformas de 1992 e 2000 não alterou o direcionamento de recursos em favor dos grandes produtores haja visto que os repasses ainda são em grande parte baseados em escala de produção ou no nível de produto mais recente.
} 
Já os gastos de intervenção traduzem-se em custos de estocagem, tanto pública quanto privada (quando definida para fins públicos). Nesse processo, as companhias adquirem os produtos estocando-os por certo período e sustentando preços de mercado. Embora menos presente que nos anos da década de 1980, essa política ainda é relevante para vários produtos.

Ainda que os subsídios à exportação e os gastos de intervenção sejam significativos para muitas commodities, saliente-se que os setores com maior grau de intervenção são aqueles que ainda apresentam políticas de preços garantidos, em especial lácteos e açúcar.

\subsubsection{A economia política na PAC}

Segundo Howarth (2000), os objetivos originais da PAC eram: aumentar a produtividade agrícola, assegurar um padrão de vida considerado justo para a população agrícola, estabilizar o mercado doméstico para os respectivos bens, assegurar a disponibilidade de excedentes e assegurar preços domésticos aos consumidores. Para esse mesmo autor, os objetivos iniciais da PAC remanescem das filosofias e dos mecanismos de intervenção das políticas alemã e francesa da década de 1870, notadamente protecionistas ${ }^{6}$.

De acordo com Abramovay (1999), as duas primeiras décadas de implantação da PAC correspondem a uma notável convergência das organizações profissionais agrícolas e das autoridades de Bruxelas em torno da necessidade de se organizar o setor sobre a base de um padrão único de estabelecimento produtivo.

\footnotetext{
${ }^{6}$ De fato, Abramovay (1999) reconhece que já desde o início dos anos 1950 o eixo de formação da Comunidade é franco-alemão. Segundo o referido trabalho, a França condicionou a própria liberalização das tarifas industriais e a participação européia na Rodada Kennedy das negociações do Gatt à garantia de escoamento de sua produção.
} 
A trajetória de constituição da PAC esteve, sob certo aspecto, ligada aos esforços concentrados de grupos de produtores bem organizados que encontraram eco nas dificuldades de abastecimento alimentar europeu ao final da Segunda Guerra Mundial. A ação lobbista de um lado e uma crença quase que mercantilista de muitos líderes europeus do outro criaram espaço para o estabelecimento e sustentação políticos da Política Agrícola Comum.

Seguindo a idéia de Krueger (1974), citada em Kaempfer et al. (2002), esse fenômeno é muitas vezes reforçado porque o relativo sucesso de grupos protegidos reduz a confiança da população local na justiça dos mercados, o que no caso europeu deve ter se tornado bastante forte às vésperas do Tratado de Roma. Isso criaria espaço para uma ainda maior intervenção governamental e estimularia um círculo vicioso de proteção, e de proteção à proteção.

De fato, a PAC atingiria seu objetivo quanto à superação da fragilidade no abastecimento interno de alimentos; todavia, esses êxitos, obtidos com apoio de intervenção estatal maciça, geraram fortes distorções tanto em termos de produção (as famosas montanhas de manteiga, etc.) quanto de preços, além de erigir barreiras desmesuradas no acesso ao mercado comunitário e de sustentar artificialmente a competitividade externa de um setor econômico em declínio.

Tal manutenção artificial do setor agrícola viu-se em grande parte construída a partir das Organizações Comuns de Mercado (OCM's). No modelo operante das OCM's um órgão de intervenção (por setor e/ou por produto) compra os excedentes de produção local quando o preço de mercado interno cai abaixo de um preço de referência estipulado pela UE, preços de regra acima dos do mercado mundial.

Ao mesmo tempo, elevadas tarifas de importação isolam o mercado local da oferta externa, e do lado das exportações comunitárias, os altos preços praticados domesticamente são compensados na forma de restituições às exportações, cobrindo-se a diferença entre o preço sustentado de mercado interno e o preço mundial de exportação. 
De acordo com Jank et al. (2003), essa foi a fórmula encontrada para que os preços dos produtos agropecuários da Comunidade Européia permanecessem em níveis de $50 \%$ a $100 \%$ acima dos preços internacionais por várias décadas.

Esse procedimento de apoio ao produtor agrícola comunitário criaria condições propícias à formação dos respectivos e organizados grupos de interesse, como nos casos de açúcar, frutas e legumes, tabaco, carne bovina, carne suína, carne de aves e lácteos. O elevado nível de proteção fixado para leite, carnes e cereais atesta que os produtores interessados dos países nórdicos, França e Alemanha foram os mais ágeis em garantir a renda de suas atividades agrícolas no embrião da Comunidade, então inspirada numa visão de welfare state.

$\mathrm{Na}$ prática, todos os desembolsos efetuados no contexto da PAC foram centralizados no Fundo europeu de orientação e de garantia à agricultura (Feoga), estabelecido com a meta de dar uma expressão de fato aos princípios de solidariedade e responsabilidade comum entre os países membros do bloco. O Fundo opera por meio de agências nacionais e os preços de intervenção por ele implementados são fixados anualmente pelo Conselho de Ministros em Bruxelas. Sob tal ponto, observe-se a distribuição de gastos do Feoga nos anos recentes e seus valores projetados. 
Tabela 3. Participação (\%) das atividades nos gastos do Feoga.

\begin{tabular}{lccccc}
\hline \multicolumn{1}{c}{ Atividade de produção } & $1989(\%)$ & $1993(\%)$ & $1997(\%)$ & $2001(\%)$ & $2005(\%)$ \\
\hline Grãos & 25,6 & 30,7 & 43,1 & 44,4 & 41,5 \\
Óleo de oliva & 6,0 & 7,1 & 5,4 & 5,4 & 5,0 \\
Frutas e vegetais & 4,2 & 4,8 & 3,9 & 4,5 & 4,1 \\
Açúcar & 8,1 & 6,3 & 4,0 & 4,1 & 3,8 \\
Tabaco & 4,7 & 3,4 & 2,5 & 2,4 & 2,2 \\
Fibráceas & 2,5 & 2,5 & 2,2 & 2,0 & 1,8 \\
Vinho e derivados & 4,7 & 4,4 & 2,5 & 1,9 & 1,7 \\
Outros produtos de origem vegetal & 0,8 & 0,8 & 0,7 & 1,0 & 0,9 \\
Vegetais processados & 0,9 & 1,5 & 0,9 & 0,9 & 0,8 \\
Subtotal 1 (produção vegetal) & 57,5 & 61,5 & 65,2 & 66,6 & 61,8 \\
Carne bovina & 10,0 & 11,5 & 16,3 & 13,3 & 17,0 \\
Leite e derivados & 20,4 & 15,1 & 7,7 & 7,4 & 9,7 \\
Carne ovina & 6,0 & 5,2 & 3,5 & 4,5 & 4,2 \\
Outros produtos de origem animal & 0,0 & 0,4 & 0,2 & 0,3 & 0,2 \\
Peixes & $-0,1$ & 0,1 & 0,1 & 0,2 & 0,2 \\
Carne suína & 1,1 & 0,6 & 1,2 & 0,1 & 0,1 \\
Ovos e carne de aves & 1,0 & 0,8 & 0,2 & 0,0 & 0,0 \\
Subtotal 2 (produção vegetal) & 38,4 & 33,7 & 29,2 & 25,8 & 31,4 \\
Subtotal gasto em produção & 95,9 & 95,2 & 94,4 & 92,4 & 93,2 \\
\hline
\end{tabular}

Fonte: elaborado pelo autor com base no Official Journal of the European Communities (OJEC) (1998)

Ao mesmo tempo em que os mecanismos da PAC assumiam centralidade nos gastos orçamentários totais da UE, já na metade da década de 1980 acirravam-se os questionamentos em torno dos inconvenientes da Política.

Jank et al. (2003) apontam quatro problemas centrais recorrentemente associados à PAC: a produção de excedentes agrícolas de alto custo e baixa competitividade nos mercados mundiais, os reclamos manifestados por tradicionais exportadores de alimentos (como os EUA e os países do Grupo de Cairns), as pressões ambientalistas no próprio seio da UE e o reconhecimento de que a Política foi centralizadora de benefícios e incapaz de conter o êxodo rural. 
Esses elementos e os acordos assinados na Rodada do Uruguai em relação à produção e comércio de bens agrícolas estimularam mudanças no funcionamento da Política, e já em 1991 a Comissão Européia reconheceu que eram necessárias reformas mais radicais Esse reconhecimento levou a duas tentativas de reforma - uma em 1992 (Reforma MacSharry) e outra em $2000^{7}$ - e à proposição de uma série de mudanças da PAC em 2003.

Em 1992 houve um corte médio de 35\% nos preços de sustentação para grãos e a substituição do suporte de preços pelos pagamentos diretos ${ }^{8}$, mas as políticas para açúcar, vinho e frutas e vegetais não foram alteradas. Essa mudança gerou três efeitos importantes: impôs um freio nos gastos da Política, aproximou os preços locais dos preços mundiais, mas reforçou complexos instrumentos de controle da produção como políticas de descanso da terra e as quotas de produção.

Já a reforma de 2000 gerou um aprofundamento do processo de substituição da política de suporte de preços pelos pagamentos diretos e uma mudança de ênfase da PAC, favoravelmente às políticas de desenvolvimento rural, procurando-se adaptar a PAC às limitações orçamentárias e às novas necessidades atreladas ao recebimento dos países da Europa Centro Oriental.

Segundo Marsch \& Tarditi (2003) esses processos foram mais profundos em cereais (pagamentos por área não atrelados a cultura específica), carne bovina (com a montagem de um intrincado sistema de pagamentos por prêmios), e lácteos (corte de $17 \%$ no preço de intervenção doméstico, contrabalançado pela prorrogação do sistema de quotas de produção até 2008).

\footnotetext{
${ }^{7}$ Ainda que a maioria dos autores centre suas observações sobre as reformas de 1992 e 2000 , autores como Howart (2000), advogam que a Política Agrícola Comum já houvera sido objeto de modificações em 1969, 1977, 1984 e 1988, menos visíveis que os processos de 1992 e 2000, mas também importantes. Abramovay (1999) ressalta as tentativas de contingenciamento da produção do início da década de 1980, sistematicamente mal sucedidas segundo o autor.

${ }^{8}$ Àquele momento ainda vinculados à produção média por unidade de fator, conforme Bureau (2002)
} 
$\mathrm{O}$ que essas medidas apontaram foi essencialmente $\mathrm{o}$ fato de que os dirigentes europeus estavam rearranjando as rubricas da Política às necessidades de financiamento dos membros ingressantes do Leste Europeu, ou seja, estruturando programas focados antes em desenvolvimento rural que em intervenção de mercado.

Como resultado das reformas de 1992 e 2000, os pagamentos diretos tornaram-se centrais para grãos e carnes bovinas, enquanto que para manteiga, leite em pó e açúcar, órgãos de intervenção passaram a executar a política de compras de excessos de oferta garantindo um preço mínimo aos produtores. Para vinho, carne suína e frutas e vegetais aprimoraram-se os mecanismos de estocagem privada quando do excesso de oferta.

Já no caso do açúcar e do leite, os preços administrados somente foram garantidos se respeitadas quotas de produção. Para a produção além das quotas os respectivos produtores viram-se submetidos a taxas para dispor da produção excedente. Apenas no caso do trigo os preços garantidos foram aproximados dos preços mundiais.

Um detalhamento dos processos de reforma da PAC em 1992 e 2000 foi posto como Anexo B do trabalho, desagregando-se as medidas por produtos afetados.

Embora a PAC não seja uma barreira tarifária, as OCM's nela estruturadas constituem uma proteção direta aos produtores domésticos, restringindo o espaço de acesso àquele mercado. Sob tal prisma, as mudanças de 1992 e 2000, ao intensificarem o uso de pagamentos diretos ${ }^{9}$ mantiveram suporte elevado para diversos produtos.

\footnotetext{
${ }^{9}$ Quanto a este ponto, na linha de raciocínio de Bureau (2002), embora a mudança de sustentação de preços para pagamentos diretos tenha provavelmente aumentado a eficiência bem com a transparência do apoio, o volume de pagamentos é tal que eles agora excedem a renda agrícola em muitas fazendas. Isso tem levantado problemas de aceitabilidade das reformas desde que os fazendeiros sentem que seu trabalho não está sendo remunerado e que o que eles recebem é um tipo de caridade.
} 
Isso pode ser aferido pela tabela a seguir, na qual consta o coeficiente nominal de suporte publicado pela OCDE. Trata-se de um indicador do nível de suporte calculado pela OCDE para os países do consórcio. Pela definição, o nível de intervenção sobre uma produção é tanto maior quanto mais distante o valor calculado da unidade ${ }^{10}$.

Tabela 4. Coeficiente nominal de suporte ao produtor em itens selecionados.

\begin{tabular}{lccccccccc}
\hline & 1986 & 1988 & 1990 & 1992 & 1994 & 1996 & 1998 & 2000 & 2002 \\
\hline Trigo & 2,15 & 1,80 & 1,59 & 1,89 & 2,14 & 1,45 & 1,97 & 1,86 & 1,85 \\
Trigo duro & 2,25 & 1,79 & 2,58 & 2,28 & 2,38 & 2,58 & 2,58 & 2,91 & 3,06 \\
Cevada & 2,59 & 1,85 & 1,93 & 2,25 & 3,22 & 1,68 & 2,90 & 1,85 & 2,04 \\
Aveia & 1,86 & 1,16 & 1,52 & 1,83 & 2,51 & 2,49 & 3,33 & 3,49 & 2,25 \\
Milho & 2,13 & 1,78 & 2,04 & 2,19 & 1,72 & 1,43 & 1,69 & 1,71 & 1,39 \\
Arroz & 2,16 & 2,34 & 2,26 & 2,43 & 2,40 & 1,35 & 1,33 & 1,20 & 1,58 \\
Outros grãos & 2,50 & 1,74 & 1,89 & 2,21 & 3,12 & 1,76 & 2,95 & 1,99 & 2,07 \\
Óleo vegetal & 2,63 & 2,11 & 2,76 & 2,06 & 1,67 & 1,67 & 1,55 & 1,65 & 1,46 \\
Açúcar & 2,70 & 2,23 & 1,83 & 2,72 & 2,51 & 1,86 & 2,16 & 1,99 & 1,96 \\
Leite & 2,69 & 2,03 & 2,66 & 2,46 & 2,33 & 2,06 & 2,35 & 1,73 & 1,93 \\
Carne bovina & 2,89 & 1,89 & 2,15 & 2,15 & 1,93 & 2,47 & 3,09 & 2,93 & 4,87 \\
Carne ovina & 2,64 & 4,08 & 3,52 & 3,36 & 2,60 & 2,43 & 2,31 & 2,11 & 1,61 \\
Carne suína & 1,28 & 1,29 & 1,02 & 0,97 & 1,14 & 1,20 & 1,19 & 1,33 & 1,35 \\
Carne de aves & 1,28 & 1,37 & 1,51 & 1,69 & 1,83 & 1,75 & 1,40 & 1,58 & 1,61 \\
Ovos & 1,19 & 1,16 & 1,07 & 1,11 & 0,99 & 1,07 & 1,10 & 1,05 & 1,06 \\
\hline
\end{tabular}

Fonte: Organization for Economic Cooperation and Development (OECD) (2003)

Em termos de suporte comunitário a setores específicos, há uma grande variabilidade em níveis de apoio concedido, mas ressaltem-se aqueles verificados para carne bovina, trigo duro e aveia, quando medidos pelo coeficiente nominal de suporte ao produtor. Mesmo os valores do coeficiente em 2002 ainda mostram uma atividade agrícola fortemente subsidiada na UE.

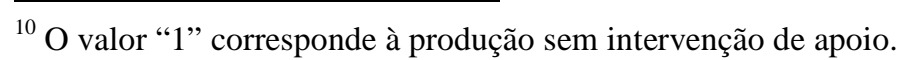


Ante tais considerações, mesmo que as reformas iniciadas em 1992 e 2000 tenham sido um primeiro passo com vistas ao arrefecimento das políticas de suporte à agricultura na UE, a política continuou focada no suporte de renda ao produtor agrícola local. Concorda-se com o argumento de Marsch \& Tarditi (2003) no sentido de que a substituição da política de preços garantidos pelos pagamentos diretos não se constituiu numa mudança de concepção da PAC.

Ainda que reconhecendo o caráter ultrapassado da Política Agrícola Comum, obstáculos efetivos à mudança de nível real de suporte subsistem. Sob tal aspecto, a literatura que trata do tema reconhece três componentes fundamentais, a saber:

- a capitalização de grande parte dos recursos alocados pela PAC em preços de ativos (terra, direitos de produção, direitos de premiação, etc.) que são de difícil valoração fora do setor agrícola;

- a regra de tomada de decisão e financiamento da PAC: tida como permissiva porque dilui os custos da Política entre os países membros ao mesmo tempo em que seus benefícios são facilmente absorvidos;

- para uma parcela não desprezível da população dos países membros a PAC ainda é um típico caso de política de sucesso na trajetória de construção da UE. Para esses europeus e suas organizações, os custos financeiros e ambientais e os efeitos distorcivos em nível de alocação interna de fatores de produção não são claros ou representam um custo relativamente justo. Bureau (2002) exemplifica que os mecanismos de preço de intervenção desenvolvidos à década de 1960 ainda impõem 
custos de alimentação nada desprezíveis para os consumidores e já teriam sido abolidos há muito tempo se os consumidores tivessem mostrado séria objeção ${ }^{11}$.

Ademais, em países como a França, ainda vigora um sentimento de trauma herdado face à escassez de alimentos dos anos entre a Primeira e a Segunda Guerras Mundiais. Como resultado, muitas populações dos países membros da UE passaram a ver na produção agrícola nacional um ícone de identidade. Esse sentimento consolidou a idéia de que os preços mundiais não têm significado para o abastecimento agrícola ou agroindustrial doméstico, argumento que se cristalizou como um moto perpétuo do lobby agrícola comunitário ${ }^{12}$.

É inegável que os lobbies agrícolas têm papel ativo em países-chave no concerto político local, particularmente na Itália, França e Alemanha. Exemplo disso:

“... foi mostrado nas negociações da Agenda 2000 quando, à par as propostas da Comissão Européia de cortes nos preços mínimos garantidos e introdução de novos pagamentos diretos em 2003 para o regime de lácteos, com uma gradativa redução das quotas de produção até 2006, o Comitê de Agricultura adiou a proposta para 2005 e concordou que o regime fosse apenas revisto em 2003, ...”. (UKFG, 2002b)

\footnotetext{
${ }^{11}$ De acordo com Marsch \& Tarditi (2003), os consumidores podem se sentir seguros porque uma grande parcela de sua oferta alimentar é produzida localmente, ou porque eles se sentem beneficiados pelo impacto sobre o meio ambiente que o tipo de produção promovida pela PAC exerce, ou mesmo em função da simples manutenção de comunidades rurais, que não seriam viáveis em um ambiente competitivo.

${ }^{12}$ Autores como Elliott \& Heath (2000) inserem esse fenômeno no contexto da chamada "Lógica da ação coletiva". Segundo tal definição grupos sociais menores e coesos em seus interesses são mais efetivos na defesa de suas propostas que grupos sociais maiores e difusos em seus interesses. Bechker (1983) nota que “... grupos bem sucedidos politicamente tendem a ser pequenos relativamente ao tamanho dos grupos taxados para pagar os benefícios daqueles primeiros." Isso se alinha com o tamanho proporcionalmente reduzido das associações que de fato hoje pertencem ao setor agrícola comunitário.
} 
Assim, a configuração dos lobbies agrícolas locais e a concentração de recursos em torno de uma marcante política de intervenção formam as duas faces de uma mesma moeda e são vetores de forças que se realimentam. Abramovay (1999) já identificava que os estabelecimentos recebendo as maiores ajudas diretas eram os mais especializados, voltados à produção de grãos e carnes.

É sintomático nesse processo que tanto os maiores volumes de apoio estejam concentrados nos produtores mais capitalizados (vide figura a seguir) ao mesmo tempo em que a taxa de mobilização das corporações agrícolas é superior à dos sindicatos de trabalhadores nos principais países do bloco (conforma a próxima tabela).

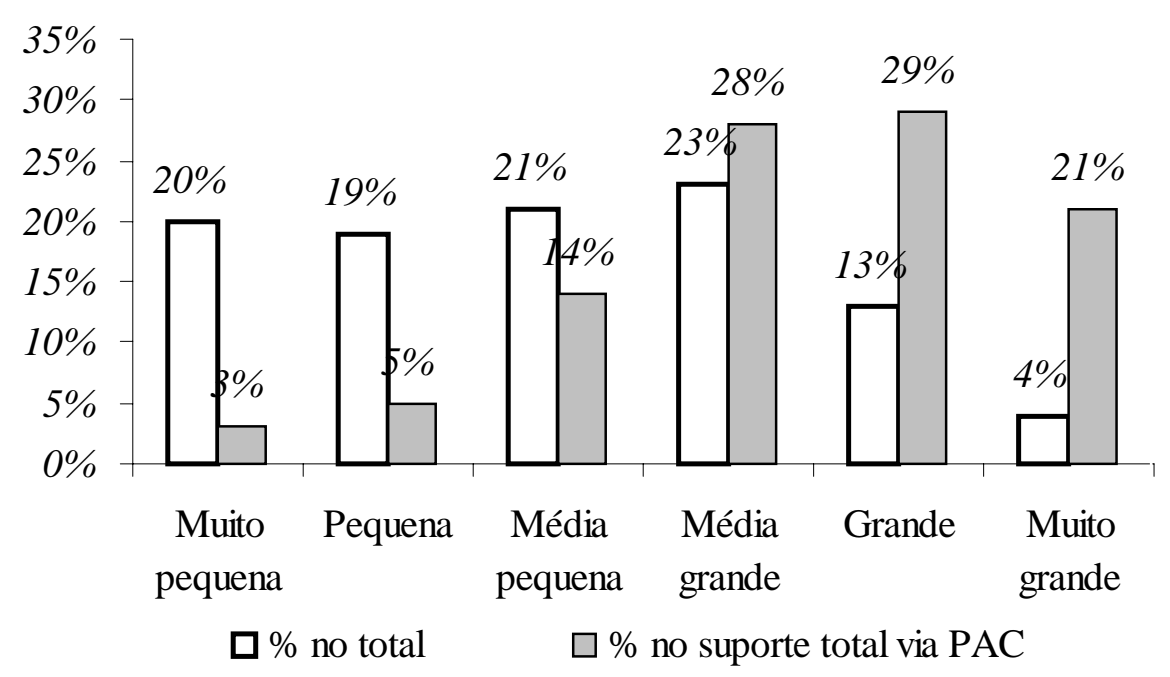

Figura 4 - Agricultores comunitários por tamanho de propriedade e suporte recebido via Política Agrícola Comum.

Fonte: Australian Bureau of Agricultural and Resource Economics (ABARE) (2000), citada em UKFG (2002a)

Notas: Propriedades classificadas por margens brutas (em euros) por fazenda: muito pequena (até 4.800), pequena (4.800 a 9.600), média pequena (9.600 a 19.200), média grande (19.200 a 160.000), grande (160.000 a 400.000) e muito grande (acima de 400.000). 
Tabela 5. Taxa de mobilização das organizações agrícolas em países-chave da UE.

\begin{tabular}{lcc}
\hline \multicolumn{1}{c}{ Membro UE } & Sindicatos agrícolas & Sindicatos de trabalhadores \\
\hline França & $54,5 \%$ & $23,0 \%$ \\
Alemanha & $90,0 \%$ & $40,0 \%$ \\
Grã-Bretanha & $78,0 \%$ & $50,0 \%$ \\
Itália & $80,0 \%$ & $36,5 \%$ \\
\hline
\end{tabular}

Fonte: Keeler (1996), citado em Elliott \& Heath (2000)

Para autores como Baldwin (1985), esse não é um fato casual porque o nível de proteção estaria diretamente relacionado ao número e grau de coesão dos sindicatos nacionais interessados. O gráfico e a tabela precedentes são também importantes em retratar a dificuldade que existe em se saber precisamente a direção de causalidade que há entre o lobby agrícola europeu e a respectiva proteção de mercado.

Para Abramovay (1999) a própria modernização da agricultura européia consistiu num espetacular processo de cogestão da concentração de recursos produtivos e de subsídios públicos entre as mãos de um setor que conseguiu conquistar junto à sociedade e ao Estado - com maior ou menor sucesso, dependendo da história de cada país, é claro - o lugar de legítimos administradores daquilo que poderia ou não ser feito com o espaço rural.

Além desses pontos a favor do status quo, Kaempfer et al. (2002) ressaltam o argumento de que os eleitores são antes trabalhadores e depois consumidores. Essa ordem dos fatos advogaria a favor de políticas que sustentem as pessoas fora das áreas urbanas, minimizando-se os impactos em termos de desemprego.

Os próprios ganhos associados ao livre comércio são mais difíceis de identificar que as respectivas perdas. Corden (1974) já afirmava que as pessoas valoram mais aquilo que elas já possuem do que aquilo que elas possam vir a ganhar (os ganhos potenciais do livre comércio nesse caso). Na UE, esse pode ser um componente significativo para explicar a permanência da política de suporte à agricultura. 
No sentido exatamente contrário, há vários argumentos convergindo para um aprofundamento das reformas de 1992 e 2000.

De um lado, citam-se a proporção do orçamento assumida pela PAC e o reconhecimento por contribuintes importantes do bolo - como a Alemanha - de que seus custos estão sendo proporcionalmente maiores que seus benefícios sob a atual estrutura da política agrícola comunitária. Isso ocorre porque a principal fonte de receita do orçamento comum é a transferência de recursos dos Estados Membros, proporcional ao produto interno bruto no total da Comunidade. Já os encaixes da PAC entre as várias regiões da UE obedecem a critérios muito menos objetivos e muito mais políticos.

Em segundo lugar, há também maior visibilidade dos problemas ambientais oriundos da produção capital intensiva motivada pela PAC.

Como terceiro ponto, os atuais mecanismos de financiamento da PAC são insuficientes para um bloco econômico que passou a ser exportador líquido em muitos itens agrícolas e agroindustriais. Mesmo porque, as receitas aduaneiras oriundas das tarifas que protegem a produção local são limitadas para cobrir os gastos com estocagem dos respectivos excessos de oferta doméstica, bem como para subsidiar a exportação desses mesmos excedentes.

Por fim, ao favorecer a propriedade agrícola estruturada para produzir em larga escala, os benefícios do suporte de preços tendem a se ver concentrados nos agricultores de maior porte, em detrimento das pequenas e médias produções e de seu emprego agrícola, conforme ilustrado anteriormente.

Em 2002, impulsionada por tais elementos, a Comissão Européia apresentou o mid term review como exercício de discussão de futuras reformas da Política. Em realidade, as propostas do mid term review serviram como laboratório para as reformas aprovadas pela União Européia em 26 de junho de 2003, agora sim um conjunto de mudanças aprovado e com prazo de implementação estabelecido. 


\subsubsection{O mid term review e a reforma da política em 2003}

Tendo-se em vista as pressões por mudanças efetivas na PAC, o mid term review foi apresentado pela Comissão Européia como exercício de discussão de futuras reformas da Política. Ali, observando-se os aspectos da reforma voltados à política de mercado, a Comissão Européia propôs:

- um corte de até 5\% nos preços de intervenção dos cereais e um novo sistema de proteção tarifária;

- uma redução no pagamento adicional para o trigo e um novo prêmio de qualidade;

- uma queda compensada no preço de intervenção para o arroz;

- $\quad$ ajustes nos setores de ração para animais, cereais e nozes;

- subsídios limitados a 300.000 euros por fazenda;

- quatro opções de política oferecendo uma reforma mais profunda no setor lácteo;

- pagamentos sujeitos ao cumprimento de padrões de segurança alimentar, estatutos ambientais e de bem-estar animal (cross-compliance), contemplando tanto a terra agrícola produtiva quanto a em descanso;

- estruturação de um sistema comunitário de auditoria para os produtores profissionais;

- descanso compulsório de 10 anos para a terra agriculturável, alinhado com os compromissos cruzados para produtores beneficiados com mais do que 5.000 euros/ano em pagamentos diretos;

- implantação de um sistema de modulação dinâmica em termos compulsórios para todos os países da UE, produzindo-se reduções progressivas, lineares e anuais de $3 \%$ 
nos totais de pagamentos diretos, até uma queda acumulada de $20 \%$ nos pagamentos diretos. A proposta previu que os recursos economizados via sistema de modulação poderiam ser redistribuídos às regiões mais pobres e de produção extensiva através das rubricas de desenvolvimento rural da PAC.

Por seu caráter menos encorajador à produção agrícola capital intensiva, os próprios grupos ambientalistas a defenderam como progressista. Para Marsch \& Tarditi (2003), o mid term review proposto pela Comissão Européia continha duas informações chave. Primeiro, que o modelo europeu de agricultura permaneceu não contestado em sua concepção original, mas sim melhor adequado às restrições orçamentárias, externas (negociações) e internas (expansão) da UE. Segundo, que a ventilada idéia de renacionalização da política agrícola (volta aos Estados Membros) era descartada.

Em realidade, as propostas do mid term review constituíram-se num ensaio para as reformas anunciadas pelo bloco em 26 de junho de 2003. Nessa data, a União Européia aprovou um conjunto de medidas que marcam um terceiro ponto nítido de reforma na política agrícola comunitária.

O horizonte de implementação das medidas iniciar-se-á em 1\%01/05 e estender-se-á até 2013; portanto, tais modificações da PAC terão seus impactos reais distribuídos no médio prazo. Os pontos principais das medidas projetadas compreendem $^{13}$ :

- adaptação da política agrícola do bloco para a recepção dos novos membros;

- mudanças no sistema de pagamentos diretos, transformando os pagamentos desvinculados da produção em um pagamento único e convertendo as políticas de apoio monitorado e limitado em políticas de apoio permitido pela OMC;

\footnotetext{
${ }^{13}$ Esse ponto de análise das reformas da PAC baseou-se no trabalho de Jank et al. (2003)
} 
- a reforma proposta referiu-se apenas às políticas de apoio, mantendo inalteradas as estruturas tarifárias praticadas até então;

- os produtos mais atingidos pela reforma foram os cereais e as carnes bovina e ovina, em continuidade às mudanças já iniciadas nas reformas precedentes;

- produtos de interesse do Brasil como lácteos somente entrarão no sistema de pagamento único em 2008, enquanto o fumo, o algodão e o óleo de oliva terão alterações ainda sob análise. O regime europeu de açúcar também não foi modificado.

Centrada em mudanças na política de subsídios agrícolas comunitários, a reforma de 2003 confirmou parte dos prognósticos do mid term review consolidando quatro categorias de mecanismos de intervenção na política agrícola da UE: crosscompliance, modulação, disciplina financeira e national envelopes.

O cross-compliance significa um critério de condicionalidade, segundo o qual, o pagamento direto está sujeito ao cumprimento de padrões de sanidade animal e vegetal e respeito ao meio ambiente e ao bem-estar dos animais. Por se tratar de padrões de qualidade dos alimentos produzidos, esse componente guarda um potencial para a formatação de futuras barreiras não tarifárias no acesso ao mercado agrícola comunitário.

A modulação traduz-se num mecanismo pelo qual ocorre uma realocação orçamentária dos recursos da PAC, reduzindo-se os pagamentos diretos aos grandes produtores em favor do fortalecimento dos recursos disponíveis às políticas de desenvolvimento rural.

A disciplina financeira trata-se da imposição de um teto orçamentário aprovado para a PAC até 2013, incluídos os recursos alocados aos novos membros. Isso permitirá à comissão fazer cortes extras nos auxílios diretos sob a eminência de superação dos limites orçados, a partir de 2007. 
Por fim, os national envelopes configuram pagamentos suplementares disponibilizados para o cumprimento dos novos padrões de segurança e qualidade dos produtos, conforme estipulado pela reforma.

De fato, em itens relevantes para o Brasil (oleaginosas, carne bovina, cereais, e leite) não houve alterações significativas, uma vez que os produtores europeus com acesso ao velho sistema continuam a ser subsidiados não diretamente pela produção, e ainda poderão gerar níveis elevados de produto via capitalização das respectivas unidades produtivas.

Tímida em profundidade e abrangência, a reforma de 2003 pode ser tomada como um novo momento de mudança lenta, gradual e segura, uma espécie de ajuste de sintonia fina em relação às pressões externas e internas não atendidas ou contempladas pelas reformas anteriores.

Ademais, pode-se advogar em alguma medida que o momento e o formato das mudanças foram manejados pela UE no sentido de aliviar as pressões que a Comunidade receberia no tema agricultura durante as negociações da Rodada de Doha, possibilitando ao Comissário europeu o argumento de que a UE já fez as concessões devidas na área de subsídios, de modo que não se comprometeria em concessões profundas na abertura de seus mercados agrícolas.

Nota-se, após essa discussão, um reiterado caráter insuficiente das mudanças empreendidas no passado recente da Política Agrícola Comum. Isso permite concordar com o raciocínio de Stoeckel (2000) de que a proteção à agricultura em economias como a UE tem criado forças políticas poderosas que bloqueiam a liberalização comercial. Apenas forças igualmente poderosas podem mobilizar um processo de nítida mudança. No caso da Europa unificada, nenhum dos contra pesos têm se mostrado individualmente forte o bastante para atuar na direção de uma efetiva mudança que solucione as contradições internas e externas da PAC. 


\subsection{A PAC no quadro institucional da UE}

É comumente aceito que além das estruturas econômicas e demográficas, instituições políticas também têm um impacto sobre o poder político dos diferentes grupos de interesse e mesmo sobre o resultado da política agrícola de um país.

No caso do bloco europeu, a proteção de acesso ao mercado e a própria Política Agrícola Comum estão diretamente relacionadas ao quadro institucional da UE. Em grau de hierarquia decrescente, é de se destacar:

- a Comissão Européia: dotada de amplo grau de liberdade quanto à concepção e implementação da política comercial do bloco. Trata-se do nível institucional que administra as políticas (inclusa a PAC) e que representa a Comunidade nas negociações com terceiros países;

- o Conselho de Ministros: canal principal entre os Estados Membros e a UE (supranacional). Constitui-se no núcleo de real poder executivo e, em assuntos afetos à agricultura, possui poder de decisão em última instância ${ }^{14}$;

- o Parlamento Europeu: detém o poder de ratificar ou vetar acordos de associação negociados pela Comissão Européia e pelo Conselho de Ministros. Nas questões relacionadas à agricultura (exceto aquelas ligadas à saúde humana), o Parlamento Europeu está hierarquicamente abaixo do Conselho de Ministros;

- a Diretoria Geral de Agricultura: corpo técnico que está direta ou indiretamente sob as ordens do Comissário para Assuntos Agrícolas da UE; e

\footnotetext{
${ }^{14}$ Marshi \& Tarditi (2003) sustentam que é justamente junto ao Conselho de Ministros que os grupos agrícolas da UE conseguiram canalizar pressões voltadas à sustentação de preços garantidos historicamente superiores àqueles quer vigoravam internamente aos países membros antes do Tratado de Roma em 1957.
} 
- a Corte Européia de Auditores: revisa os acordos e projetos de execução que sejam contemplados pela PAC ou a afetem.

Segundo Bureau (2002), o atual status quo das regras de maioria qualificada implica que a PAC só pode ser modificada pelo Conselho de Ministros com 62 votos num total de 87 votos. O número de votos devido a cada Estado membro é de regra ponderado por fatores como PIB e população dos países membros no total da Comunidade, havendo uma distribuição de votos projetada sob o acesso dos futuros membros.

Efetivamente, uma proposta de mudança da PAC pode surgir de um dos comitês da Comissão Européia, do Parlamento Europeu ou de um dos Estados Membros, mas a Comissão é o único órgão legitimado a submeter uma proposta ao Conselho de Ministros e ao Parlamento Europeu.

De início, com a anuência do Presidente ${ }^{15}$ do Conselho de Ministros, a proposta é incluída na agenda do Conselho. No caso da PAC em específico, o Conselho de Ministros de regra submete a proposta de modificação a uma revisão do Comitê Especial de Agricultura.

O passo seguinte é submeter a proposta votada e referendada (não mais necessariamente a proposta inicial) ao Parlamento Europeu, que opina e pode fazer emendas nesse estágio de tramitação. Tais emendas podem ser vetadas pelo Conselho de Ministros. Nesse ponto, o Parlamento pode submeter-se aos vetos ou pressionar o Conselho de Ministros ao conferir maior dimensão pública às discordâncias.

\footnotetext{
${ }^{15}$ Cargo rotativo, o que confere maior ou menor dinamismo ao processo conforme o país com direito a indicar o Presidente do Conselho de Ministros.
} 
Acerca da dinâmica de funcionamento dessas esferas institucionais, Bouwen (2002) afirma que as corporações e sindicatos nacionais têm maior acesso ao Conselho de Ministros e à Comissão Européia, enquanto o Parlamento Europeu está mais afeto às sugestões de agentes supranacionais. Esse é um ponto importante dado o caráter mobilizado das corporações e sindicatos agrícolas em países-chave no concerto comunitário.

Esse cenário dificulta um trabalho de antilobby no caso do setor agrícola europeu pelo fato de que os setores domésticos interessados já se encontram desde muito tempo posicionados no quadro institucional que decide o grau de proteção aos setores domésticos.

\subsubsection{Interfaces da PAC com a política comercial agrícola da UE}

A PAC teve no seu princípio um papel central para manter os países da atual UE unidos em favor de um exercício maior de integração econômica, política e social. Isso, no entanto, facilitou o trabalho de grupos relativamente menores e mais organizados que preferem manter a PAC inalterada ao ressaltar seus pontos positivos e minimizar seus impactos distorcivos.

A própria eliminação das barreiras tarifárias internas aos seis países que iniciaram o projeto de integração foi condição necessária para que os fatores de produção fossem alocados com base nas vantagens comparativas de cada país e região. No entanto, isso também implicava a construção de uma estrutura tarifária que permitisse aos membros do bloco um grau de isolamento em relação aos produtores mais eficientes de terceiros países.

Mitra (1999) afirma que os lobbies provavelmente mais organizados são aqueles que têm um grande estoque de capital, funções de demanda inelásticas, poucos detentores de capital e que estão geograficamente concentrados. Essas características se aproximam do perfil dos produtores que concentram os benefícios da Política Agrícola Comum. 
Em relação às reformas empreendidas em 1992, 2000 e 2003, fica a sensação de que elas foram antes ajustes internos ao processo de expansão do bloco do que propriamente políticas de abertura comercial agrícola. Em relação à reforma de 2003, Jank et al. (2003) levam esse argumento ao limite e advogam que:

\footnotetext{
"Na realidade, a produção pode continuar elevada, e mesmo excedentária, em função dos inúmeros formatos de ajuda direta que foram criados ou expandidos na reforma. Os preços recebidos pelos produtores podem igualmente continuar elevados em decorrência da aplicação de tarifas altíssimas e quotas tarifárias, aspectos que não foram tocados na reforma." (Jank et al., 2003)
}

Nesse ponto, Abramovay (1999), reportando-se à reforma de 1992, já argumentava que não se pode negar o fato de que, pelo menos até a reforma de 1992, o peso dos recursos públicos na formação da renda agrícola comunitária é absolutamente decisivo, em que pese o discurso oficial de Bruxelas e dos próprios dirigentes profissionais agrícolas enaltecendo o desenvolvimento rural e a importância real dos mercados de qualidade, que não dependem de subvenções oficiais.

Aliás, como apontado na discussão do quadro institucional da UE, é visível a presença dos sindicatos agrícolas da Comunidade nas adjacências das principais esferas decisórias supranacionais. Abramovay (1999) reporta inclusive que a fixação dos preços garantidos era verdadeira maratona que envolvia além da proposta da Comissão Européia e seu exame pelo Conselho de Ministros a pressão do Comitê das organizações profissionais agrícolas (Copa) que, claramente, reivindicavam preços sempre superiores aos propostos pela Comissão. 
Sob tal quadro, pode-se esboçar uma figura retratando a ação do lobby agrícola europeu em duas frentes, a da política comercial (resumida numa tarifa, por exemplo) e a da Política Agrícola Comum em si.

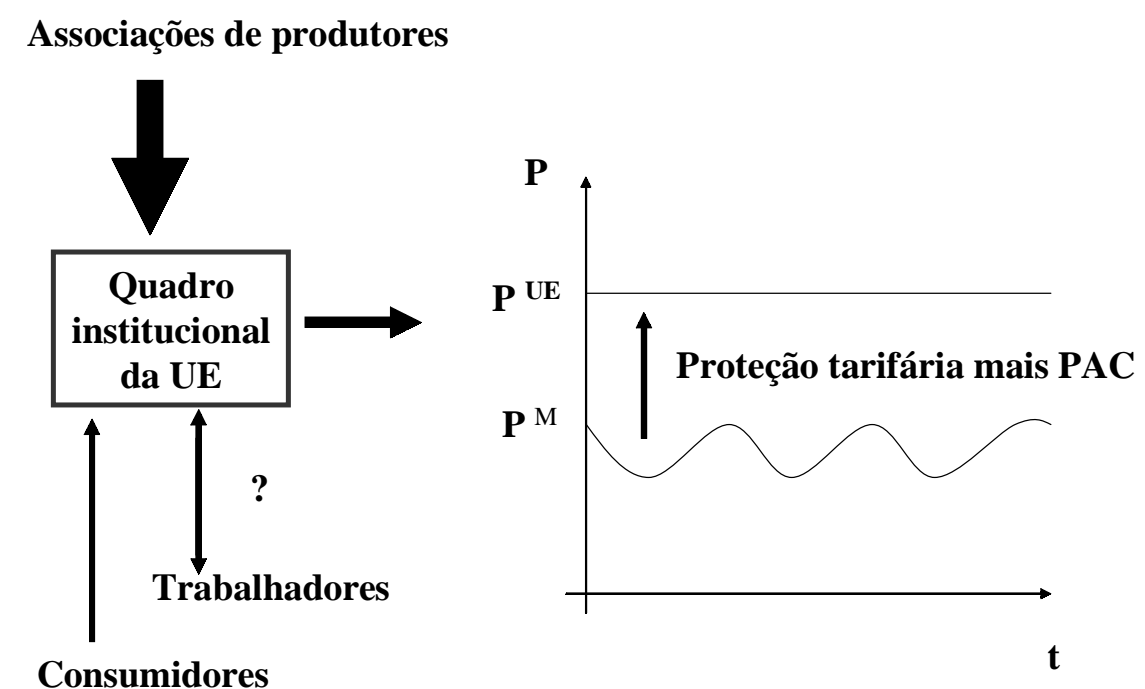

Figura 5 - Preço doméstico sustentado via PAC e via tarifas.

Notas: $\mathrm{P}^{\mathrm{UE}}$ : preço de intervenção doméstico na União Européia;

$\mathrm{P}^{\mathrm{M}}$ : preço mundial.

Isso posto, é possível argumentar que caso a proteção tarifária seja reduzida, a União Européia seria obrigada a ampliar suas políticas de suporte via PAC se quisesse manter os preços internos descolados dos preços mundiais, o que colocaria em xeque a própria política de intervenção.

Numa área econômica das dimensões da UE, as duas políticas (agrícola e comercial agrícola) se sustentam quando acionadas conjuntamente, de forma que o arrefecimento de uma delas dificilmente permitirá que a outra, sozinha, garanta o atual nível de restrição de acesso àquele mercado no caso dos produtos agrícolas. 


\subsubsection{Impactos da PAC e das tarifas agrícolas da UE}

Muitos trabalhos têm procurado mensurar os efeitos da diminuição de suporte da PAC sobre os preços internacionais dos produtos agrícolas assim como sobre os fluxos desses bens. O mesmo exercício tem sido feito em relação à eliminação de picos tarifários e de quotas tarifárias da pauta de tarifas agrícolas da UE.

Objetivamente os vários modelos e simulações raramente concordam sobre os efeitos no mercado mundial de uma reforma profunda da $\mathrm{PAC}^{16}$. Esses estudos baseiam-se no fato de que a Comunidade é o maior importador de produtos agrícolas e/ou de agrícolas processados do mundo, mesmo no contexto de proteção tarifária e das políticas de suporte engendradas na PAC.

O ferramental usado para realizar tais simulações é basicamente de duas naturezas: modelos de equilíbrio geral ou modelos de equilíbrio parcial.

Em particular os modelos de equilíbrio geral são flexíveis e abrangentes, não se limitando a mensurar impactos sobre os produtos e comércio agrícolas. Isso, via de regra, lhes confere propriedades teóricas que suportam a consistência de seus resultados. Porém, esses modelos falham em capturar maior desagregação dos bens porque a base de dados do GTAP - a mais utilizada para tais estudos - é bastante agregada e limitada em termos de definição de categorias de produtos. Além disso, no caso da pauta tarifária da UE, há uma complexa rede de acordos preferenciais de comércio com efeitos não desprezíveis sobre as orientações de fluxos comerciais, elemento que esses modelos ainda não captam perfeitamente.

\footnotetext{
${ }^{16}$ De fato, as hipóteses de partida, o grau de detalhamento do modelo utilizado, o tipo de modelagem (equilíbrio parcial, equilíbrio geral, ou modelos gravitacionais) e as próprias limitações de bases de dados condicionam os resultados finais, em especial do ponto de vista quantitativo.
} 
Já os modelos de equilíbrio parcial propiciam um tratamento mais refinado e desagregado de produtos e setores. Em contrapartida, exigem uma gama de dados bastante específicos, um preciso trabalho de especificação do modelo e, por tabela, uma grande atenção quanto à consistência do modelo em face do mundo real, vez que impactos oriundos de outros setores da economia não são considerados se esses setores foram ex ante alijados do processo de modelagem.

O trabalho de Bureau (2002) apresenta textos que tiveram essa preocupação:

- Borrell \& Hubbard (2000): sua principal conclusão é que sem a PAC os preços mundiais do açúcar subiriam em até 38\%, baseando-se num modelo aplicado de equilíbrio geral com dados do $G T A P^{17}$;

- Stout et al. (2002): trata-se de um modelo de equilíbrio parcial desenvolvido pelo consórcio ERS/Penn State/OMC, aplicando-se o enfoque dinâmico, multiproduto e multiregião que oferece uma desagregação de produtos mais ampla. A principal conclusão desse trabalho é que se as tarifas agrícolas fossem eliminadas, a produção agrícola da UE cairia $52 \%$ no caso do açúcar, $40 \%$ em carnes bovinas, $20 \%$ em lácteos, $44 \%$ em manteiga, $8 \%$ em trigo e $34 \%$ em milho;

- FAPRI (2002): também empregando um modelo de equilíbrio parcial, concluiu que o fim de todos os elementos distorcivos (tarifas, quotas tarifárias e subsídios à exportação) teria efeitos substanciais sobre os termos de troca da UE; logo, também sobre os fluxos de comércio agrícola para aquele mercado. Por esse modelo, ocorreriam maiores aumentos de preços nos produtos lácteos, carnes e grãos, com substanciais aumentos de produção em países como Brasil, Argentina e Austrália.

\footnotetext{
${ }^{17}$ Para maiores detalhes sobre o Global Trade Analysis Project ver www.agecon.purdue.edu/gtap
} 
Borrel e Hubbard (2000), citados em UKFG (2002b), extraíram duas conclusões principais sobre a PAC. Por um lado, ela estimula sensivelmente a produção e a exportação em atividades que, sem ela, teriam outra performance na economia da UE. Tais autores estimaram que as produções de lácteos como de grãos têm um produto $51,5 \%$ maior que o produto que lhes seria devido na ausência de todos os instrumentos de intervenção da PAC. Como um segundo ponto, ela deprime tanto a produção como as exportações de produtos agrícolas latino-americanos. Vide as duas próximas tabelas.

Tabela 6. Mudança estimada no produto, exportações e importações da UE em função da PAC.

\begin{tabular}{|c|c|c|c|}
\hline Produto & Produção (\%) & Exportações (\%) & Importações (\%) \\
\hline Agricultura (exceto grãos) & 809,1 & 9.900 & 220 \\
\hline Grãos & 51,5 & 9.900 & 540 \\
\hline Lácteos & 51,5 & 9.900 & 2.000 \\
\hline Produção animal & 29,9 & $-22,5$ & 370 \\
\hline Carnes & 17,6 & 4.900 & 350 \\
\hline Outros alimentos & 3,1 & $-24,2$ & -19 \\
\hline
\end{tabular}

Fonte: Borrel e Hubbard (2000)

Nota: os valores referem-se a mudanças em \% (sobre os volumes) da situação com a PAC vis a vis à de sua ausência. 
Tabela 7. Queda estimada de produção e exportação dos países latino-americanos em função da PAC.

\begin{tabular}{lccc}
\hline & Produto & Produção (\%) & Exportações (\%) \\
\hline Agricultura (exceto grãos) & $-12,3$ & $-43,2$ \\
Grãos & $-2,0$ & $-29,1$ \\
Lácteos & $-3,8$ & $-45,1$ \\
Produção animal & $-5,7$ & 9,9 \\
Carnes & $-9,1$ & $-63,5$ \\
Outros alimentos & 4,2 & 17,6 \\
\hline
\end{tabular}

Fonte: Borrel e Hubbard (2000)

Nota: os valores referem-se a mudanças percentuais (sobre os volumes) da situação com a PAC vis a vis à de sua ausência.

Além disso, esses dois autores estimaram que o Brasil seria o país com maior mudança nos níveis de exportação de açúcar na ausência da PAC. As exportações Brasileiras desse produto cresceriam em torno de sete milhões de toneladas consoante seus cálculos.

Outra estimativa dos impactos da PAC, agora no setor de lácteos, é apresentada em UKFG (2002a), sugerindo-se que a liberalização nesse setor da UE resultaria numa queda de $25 \%$ nos preços do produto intrabloco. Em termos da PAC como um todo, esse mesmo trabalho aponta que por causa dos preços garantidos e das políticas de apoio os preços recebidos pelos agricultores comunitários foram em média $37 \%$ superiores aos preços do mercado mundial no exercício de 2000.

Esse mesmo texto situa duas grandes questões acerca do impacto da PAC sobre os mercados mundiais de commodities agrícolas. Primeiro, que tais impactos dependem dos regimes que a Política impõe sobre produtos específicos e do nível de presença da UE no respectivo mercado internacional. Segundo, que os setores domésticos intensamente protegidos geram excedentes de exportação, deprimindo os 
preços mundiais via subsídios de exportação, tanto no curto prazo como através de seus efeitos sobre as expectativas de preços.

A auto-suficiência da UE nos mercados de algumas das principais commodities agrícolas é bastante significativa, conforme a tabela 1 deste texto. Ali se nota um perfil superavitário do bloco em produtos como cereais, trigo, carnes (bovina, suína e de aves), queijo, manteiga e leite em pó desnatado. Nesse sentido, o efeito da PAC é o de deprimir preços mundiais nos respectivos setores por conta do suporte doméstico magnificado pelas tarifas de importação e, em alguns casos, por subsídios à exportação.

Logo, mesmo as mudanças da PAC (1992, 2000, e 2003) na direção de substituição do suporte de preços pelos pagamentos diretos não são solução clara em termos de livre comércio. Bureau (2002), UKFG (2002a), UKFG (2002b), e Marsch \& Tarditi (2003) acreditam que os pagamentos diretos nos setores de cereais, carne bovina, oleaginosas, óleo de oliva e carne caprina estimularão a competitividade dos agricultores comunitários e permitem que eles se adaptem a preços mundiais menores. E essa é uma suposição bem razoável.

\subsection{A política comercial agrícola da União Européia}

Neste ponto serão discutidos os principais instrumentos tarifários de que a União Européia se utiliza no concerto de sua política comercial agrícola. São eles: tarifa externa comum, tarifas sazonais e sistema de preços de entrada, mecanismo de gatilhos e estrutura de quotas tarifárias.

\subsubsection{Tarifa Externa Comum (TEC)}

A UE, enquanto união econômica, incorpora todas as características de uma união aduaneira; portanto, seus Estados Membros adotam uma tarifa externa comum. Antes da implementação do Acordo Agrícola da Rodada do Uruguai, o sistema de tarifas da pauta agrícola e agrícola processada da UE operava com base nas chamadas tarifas 
variáveis. Segundo Marsch \& Tarditi (2003), a PAC usava esse mecanismo para isolar os preços internos das oscilações do mercado mundial.

Esse sistema foi central na Política Agrícola Comum entre os anos de 1960 e 1990. Havia um preço de fronteira da Comunidade fixado ${ }^{18}$ para cada produto, comparável ao menor preço nos respectivos mercados mundiais. Dados esses dois preços, vigorava o seguinte mecanismo:

- a diferença entre os dois preços era coberta com um imposto sobre todas as importações do produto;

- esse imposto era variável em resposta às mudanças nos preços mundiais e em resposta às mudanças nos preços fixados para as produções tidas como sazonais.

Em se tratando de UE, é preciso também citar a existência de produtos para os quais, além da respectiva tarifa incide um componente tarifário adicional associado à porcentagem de açúcar, farinha, leite ou outro produto agrícola ou industrial presente no item sob análise. Nesses casos, o perfeito enquadramento tarifário do produto negociado depende de uma perfeita descrição do produto que se pretende colocar no mercado comunitário.

Hoje, de acordo com Brasil (2001), o corpo de tarifas que a União Européia impõe a seus parceiros comerciais pode ser dividido em dois subgrupos. O primeiro seria o das tarifas convencionais, válidas para itens originários de membros da $\mathrm{OMC}$ ou aplicadas a parceiros comerciais que tenham assinado acordo recíproco com a UE com base na cláusula NMF. Os casos restantes, incluídas as preferências tarifárias concedidas

\footnotetext{
${ }^{18}$ Essa fixação do preço de fronteira era explícita no objetivo de buscar assegurar que as importações não afetassem os preços fixados pelo Conselho de Ministros para os itens produzidos dentro da UE.
} 
pela UE, são enquadrados como tarifas autônomas. Às exportações do Mercosul para a UE aplicam-se, em princípio, os direitos convencionais.

A montagem da base de tarifas nasce de um conjunto de informações tipicamente europeu, a Tarifa integrada das Comunidades Européias (TARIC). Trata-se da origem da TEC, atualizada anualmente pela UE e dividida em duas grandes categorias: produtos agrícolas congregando capítulos 01 a 24 do sistema harmonizado, e produtos industriais, reunindo os capítulos 25 a 97 do mesmo sistema.

Esse critério de classificação não coincide com o critério $\mathrm{OMC}$, segundo o qual os produtos agrícolas compreendem os capítulos 01 a $24^{19}$ e alíneas específicas dos capítulos $29,33,35,38,41,43$, e 50 a 53 do sistema harmonizado.

A montagem da TEC em dois grupos opostos não é gratuita. Uma observação mais desagregada da pauta tarifária da UE contra o Brasil, por exemplo, põe em evidência uma forte progressividade das tarifas comunitárias em função do valor agregado ao respectivo produto (escalada tarifária). Esse é um fenômeno identificado em vários trabalhos como em Castilho (2000) e Brasil (2001).

Além da pauta tarifária em si, a implantação da PAC entre os membros comunitários engendrou o livre comércio de produtos agrícolas entre os signatários originais e posteriores do Tratado de Roma. Isso significou um aumento no número de itens e variedades disponíveis a cada membro da UE, em detrimento da oferta de terceiros países. Por um lado, limitou-se o acesso ao mercado local por meio da TEC e, por outro, expandiu-se esse mesmo mercado local disponível aos produtores de cada um dos países membros.

Em linha com Bureau (2002), é quase certo que preços sustentados e tarifas externas contribuíram para preços mais altos de produtos agrícolas ou agroindustriais para os consumidores. Isso é particularmente óbvio em países que aplicavam tarifas mais

\footnotetext{
${ }^{19}$ Exceto o capítulo 03 e dadas alíneas do capítulo 16 que se reportam a peixes ou suas preparações.
} 
baixas antes de ajustar-se à UE, como o Reino Unido e a Suécia, e nos quais os consumidores sofreram com a adoção da preferência comunitária.

Essa reserva de mercado produzida pela TEC fez com que os preços de certos bens de largo consumo na Comunidade oscilassem menos que nos mercados mundiais. Em especial no caso de frutas e vegetais, a arquitetura de uma pauta tarifária sazonal sobre os bens dos capítulos 07 e 08 do sistema harmonizado conduziu a uma estabilização positiva de preços, o que do prisma dos defensores da PAC tem justificado o recolhimento e a destruição de excedentes de oferta em certos períodos.

É claro que do ponto de vista do consumidor esse seria um argumento rebatível, dado que os preços garantidos e o acesso tarifado produzem preços de varejo acima das próprias oscilações para mais dos preços mundiais desses mesmos bens.

\subsubsection{Medições da pauta tarifária agrícola sofrida pelo Brasil na UE}

Neste ponto, cabe apresentar alguns resultados de trabalhos anteriores que já procuraram medir a pauta tarifária nos produtos agrícolas destinados à União Européia.

Bureau et al. (2000) enunciam que a tarifa média NMF que os parceiros da Comunidade enfrentam é de $18 \%$, havendo somente $8 \%$ das tarifas aplicadas maiores que 50\% no conceito EAV. O mesmo Bureau (2002) calculou os valores de 16,8\% (média ponderada pelo volume de comércio) e 17,9\% (não ponderada) no conceito NMF, utilizando-se da lista submetida pela UE à OMC e empregando um valor médio de importação (oito dígitos do sistema harmonizado) de quatro anos para a conversão das tarifas específicas em EAV's. Os dados são para 2000.

Tais tarifas agrícolas consolidadas não ponderadas constam da tabela a seguir. 
Tabela 8. Tarifa média simples da UE (\%) de acordo com Bureau (2002)

\begin{tabular}{|c|c|c|}
\hline $\mathrm{SH}$ & Descrição do produto & Tarifa consolidada EAV (\%) \\
\hline 01 & Animais vivos & 13 \\
\hline 02 & Carnes e miudezas & 30 \\
\hline 04 & Leite e laticínios & 46 \\
\hline 05 & Outros itens de origem animal & 1 \\
\hline 06 & Planta vivas e floricultura & 5 \\
\hline 07 & Produtos hortícolas & 13 \\
\hline 08 & Frutas & 12 \\
\hline 09 & Café e mates & 2 \\
\hline 10 & Cereais & 34 \\
\hline 11 & Malte, amidos e féculas & 19 \\
\hline 12 & Sementes e oleaginosos & 2 \\
\hline 13 & Gomas e resinas vegetais & 2 \\
\hline 14 & Matérias para entrançar & 0 \\
\hline 15 & Óleos animais ou vegetais & 6 \\
\hline 16 & Preparações de carne e peixes & 21 \\
\hline 17 & Açúcares e confeitaria & 21 \\
\hline 18 & Cacau e preparações & 14 \\
\hline 19 & Preparações de cereais & 20 \\
\hline 20 & Preparações de hortícolas & 25 \\
\hline 21 & Preparações alimentícias & 12 \\
\hline 22 & Bebidas e vinagres & 6 \\
\hline 23 & Resíduos de ind. alimentares & 14 \\
\hline 24 & Tabaco e manufaturados & 29 \\
\hline 29 & Produtos químicos orgânicos & 25 \\
\hline 33 & Óleos essenciais e resinóides & 3 \\
\hline 35 & Matérias albuminóides e colas & 12 \\
\hline 38 & Produtos diversos de ind. quím. & 13 \\
\hline
\end{tabular}

Fonte: Bureau (2002)

Esse mesmo estudo reconhece que somente países incluídos nos sistemas de preferência da UE de fato experimentam tarifas relativamente baixas, identificando-se a 
existência de picos tarifários em setores-chave para os países não agraciados no esquema de comércio preferencial da Comunidade ${ }^{20}$.

Já Gallezot (2002) citado em Bureau (2002) encontrou o valor de 10\% para a tarifa média ponderada (pelo volume de comércio) da União Européia, contabilizando-se os acordos preferenciais e utilizando-se de dados de tarifa da base Taric de 1999.

Mendes (2000), por sua vez, cita picos tarifários (acima de 15\%) em alimentos/bebidas, têxteis, couros, borrachas, cereais, carnes, laticínios, derivados de açúcar e tabaco. O autor baseou-se em dados de 1995 e, ao que tudo indica, utilizou-se de uma média simples.

Um trabalho adicional que também procurou medir a pauta de tarifas agrícolas da UE é o trabalho de Bouët (2003). Ali, o autor partiu de tarifas agrícolas consolidadas NMF e SGP da UE harmonizadas no nível de oito dígitos do sistema harmonizado, obtendo-se os seguintes valores de tarifas médias ${ }^{21}$ :

\footnotetext{
${ }^{20} \mathrm{O}$ autor reconhece a presença de tarifas muito altas nos setores de carne bovina (acima de $80 \%$ ), açúcar (maiores que 65\%), lácteos, grãos e frutas.

${ }^{21} \mathrm{O}$ autor calculou médias ponderadas empregando como fatores de ponderação os níveis de importações de um grupo de países de referência, composto pela UE, EUA, Japão, Canadá, Austrália, Nova Zelândia, Suíça e Noruega.
} 
Tabela 9. Tarifa média ponderada da UE em produtos agrícolas de acordo com Bouët (2003)

\begin{tabular}{|c|c|c|c|c|}
\hline $\mathrm{SH}$ & Descrição do produto & NMF intraquota (\%) & NMF extraquota (\%) & SGP (\%) \\
\hline 01 & Animais vivos & 9.7 & 32.4 & 31.9 \\
\hline 02 & Carnes e miudezas & 40.9 & 69.5 & 69.4 \\
\hline 04 & Leite e laticínios & 44.9 & 57.4 & 57.4 \\
\hline 05 & Outros itens de origem animal & 0.1 & 0.1 & 0.1 \\
\hline 06 & Planta vivas e floricultura & 9.6 & 9.6 & 7.7 \\
\hline 07 & Produtos hortícolas & 9.4 & 10.6 & 8.8 \\
\hline 08 & Frutas & 6.9 & 21.1 & 19.5 \\
\hline 09 & Café e mates & 2.1 & 2.1 & 1.7 \\
\hline 10 & Cereais & 47.2 & 72.6 & 72.6 \\
\hline 11 & Malte, amidos e féculas & 23.6 & 24.4 & 24.1 \\
\hline 12 & Sementes e oleaginosos & 0.4 & 0.4 & 0.3 \\
\hline 13 & Gomas e resinas vegetais & 1.8 & 1.8 & 1.4 \\
\hline 14 & Matérias para entrançar & 0.0 & 0.0 & 0.0 \\
\hline 15 & Óleos animais ou vegetais & 12.9 & 12.9 & 9.9 \\
\hline 16 & Preparações de carne e peixes & 21.5 & 22.2 & 17.1 \\
\hline 17 & Açúcares e confeitaria & 0.5 & 44.1 & 44.0 \\
\hline 18 & Cacau e preparações & 2.7 & 2.7 & 1.9 \\
\hline 19 & Preparações de cereais & 0.5 & 0.5 & 1.9 \\
\hline 20 & Preparações de hortícolas & 13.7 & 18.0 & 15.4 \\
\hline 21 & Preparações alimentícias & 6.3 & 6.3 & 3.9 \\
\hline 22 & Bebidas e vinagres & 1.3 & 1.3 & 1.2 \\
\hline 23 & Resíduos de ind. alimentares & 0.6 & 1.1 & 0.7 \\
\hline 24 & Tabaco e manufaturados & 0.0 & 0.0 & 0.0 \\
\hline
\end{tabular}

Fonte: Bouët (2003), a partir de cálculos do autor sobre as bases de dados Trains e Amad.

Outro apontamento relevante é o feito por UKFG (2002a), no sentido de que cerca de $44 \%$ das linhas tarifárias agrícolas da União Européia têm tarifas específicas em lugar de tarifas ad valorem, tornando os níveis de proteção de difícil comparação entre os produtos. Esse mesmo trabalho aponta altas tarifas em produtos caracteristicamente protegidos na UE: lácteos, fumo, arroz, grãos destinados à alimentação animal e carne bovina. 
São também oportunos os cálculos de WTO (2002b) quanto à tarifa média simples EAV consolidada por capítulo do comércio agrícola, no conceito NMF. Trata-se de um trabalho realizado com base na estrutura tarifária definida e divulgada pela UE em 2002.

Tabela 10. Tarifa média da UE para produtos agrícolas de acordo com WTO (2002b)

\begin{tabular}{|c|c|c|c|c|c|}
\hline$\overline{\mathrm{SH}}$ & Descrição & $\begin{array}{c}\text { Média simples } \\
(\%)\end{array}$ & $\mathrm{SH}$ & Descrição & $\begin{array}{c}\text { Média simples } \\
(\%)\end{array}$ \\
\hline$\overline{01}$ & Animais vivos & 20,6 & 19 & Preparações de cereais & 16,4 \\
\hline 02 & Carnes e miudezas & 28,3 & 20 & Preparações de hortícolas & 20,6 \\
\hline 04 & Leite e laticínios & 38,4 & 21 & Preparações alimentícias & 9,6 \\
\hline 05 & $\begin{array}{l}\text { Outros itens de origem } \\
\text { animal }\end{array}$ & 0,2 & 22 & Bebidas e vinagres & 5,5 \\
\hline 06 & Planta vivas e floricultura & 6,0 & 23 & Resíduos de ind. alimentares & 7,0 \\
\hline 07 & Produtos hortícolas & 12,7 & 24 & Tabaco e manufaturados & 18,3 \\
\hline 08 & Frutas & 9,0 & 29 & Produtos químicos orgânicos & 3,7 \\
\hline 09 & Café e mates & 3,1 & 33 & Óleos essenciais e resinóides & 2,9 \\
\hline 10 & Cereais & 39,2 & 35 & Matérias albuminóides e colas & 7,0 \\
\hline 11 & Malte, amidos e féculas & 22,2 & 38 & Produtos diversos de ind. quím. & 5,5 \\
\hline 12 & Sementes e oleaginosos & 1,8 & 41 & Peles e couros & 2,6 \\
\hline 13 & Gomas e resinas vegetais & 2,2 & 43 & Peleteria e suas obras & 1,4 \\
\hline 14 & Matérias para entrançar & 0,0 & 50 & Seda & 5,0 \\
\hline 15 & Óleos animais ou vegetais & 8,9 & 51 & Lã e pêlos finos ou grosseiros & 5,1 \\
\hline 16 & $\begin{array}{l}\text { Preparações de carne e } \\
\text { peixes }\end{array}$ & 18,5 & 52 & Algodão & 6,8 \\
\hline 17 & Açúcares e confeitaria & 21,4 & 53 & Outras fibras têxteis vegetais & 3,1 \\
\hline 18 & Cacau e preparações & 11,8 & Total & & 16,1 \\
\hline
\end{tabular}

Fonte: WTO (2002b)

Nota: valores em nível de dois dígitos do sistema harmonizado a partir de uma distribuição de 2.111 linhas tarifárias em oito dígitos de desagregação do mesmo sistema.

Outro estudo realizado nessa linha foi o de Castilho (2000), que estimou a tarifa média EAV praticada pela UE em 1999. Os respectivos valores no conceito NMF são apresentados à tabela subseqüente. 
Tabela 11. Tarifas médias da UE para produtos agrícolas de acordo com Castilho (2000)

\begin{tabular}{lcc}
\hline Descrição do produto & Tarifa média simples (\%) & Tarifa média ponderada $^{1}(\%)$ \\
\hline Produtos agrícolas & 21.0 & 18.5 \\
Produtos alimentares & 25.3 & 22.7 \\
Resíduos alimentares e alimentos para animais & 56.1 & 68.9 \\
Tabaco & 45.2 & 19.2 \\
\hline
\end{tabular}

Fonte: Castilho (2000), a partir da base de dados Trains reportando-se a 1999.

${ }^{1}$ Médias ponderadas pelos fluxos de importações bilaterais.

Como se percebe, as estimativas da tarifa agrícola média da UE variam amplamente. São quatro os fatores básicos a explicar a grande variabilidade dos resultados atingidos, ou seja:

- Qual a pauta tarifária que se está considerando? A tarifa NMF submetida à OMC e base para futuras negociações ou as tarifas disponíveis para os acordos preferenciais costurados pela Comunidade?;

- Quais as hipóteses de agregação ${ }^{22}$ assumidas para o tratamento dos dados?;

- Qual o preço usado para a conversão de tarifas específicas e mistas em ad valorem?;

- Qual o esquema de ponderação empregado para o cálculo da média final?

\footnotetext{
${ }^{22}$ Sob esse aspecto, vale o apontamento de Gallezot (2003) enfatizando que a nomenclatura da União Européia pode chegar ao nível de 14 dígitos de desagregação, identificando inclusive o porto de desembarque do produto importado.
} 


\subsubsection{Pico tarifário}

Não há um consenso na literatura quanto à definição estrita do patamar tarifário a partir do qual as tarifas encontradas são consideradas picos tarifários. De fato, os estudos avaliados trabalham com definições que variam em função das pautas tarifárias e dos países sob análise, dentre as quais podem ser destacadas as seguintes:

- segundo a WTO (2002a), para uns poucos produtos que os governos consideram sensíveis as tarifas permanecem altas. Estas tarifas são os picos tarifários. Conforme referido por Gibson et al. (2001), a OMC freqüentemente usa o termo "picos tarifários internacionais" para referir-se às tarifas acima de $15 \%$. O critério OMC é coincidente com as proposições de Hoekman et al. (2001), Mendes (2000), e Bouët (2000);

- três vezes a média aritmética simples (Laird, 1998; Michalopoulos, 1999);

- média aritmética simples mais um desvio padrão (Jank et al., 2002);

- média aritmética simples mais quatro desvios padrão, critério operacionalizado em Brasil (1999);

- o patamar de $25 \%$, que corresponderia ao limite superior de uma pauta de tarifas que fosse submetida ao processo de harmonização tarifária utilizando-se a chamada "Fórmula Suíça 25",23, de acordo com trabalho elaborado pelo USDA para a proposta norte-americana apresentada em julho de 2002 à OMC (USDA, 2002). A Fórmula Suíça já foi usada nas negociações da Rodada Tóquio para produtos industriais;

- tarifa ad valorem igual ou acima de 100\%, sugerido por Gibson et al. (2001);

\footnotetext{
${ }^{23}$ Fórmula Suíça: $\mathrm{T}_{1}=\left(\mathrm{T}_{\mathrm{o}} * \mathrm{a}\right) /\left(\mathrm{T}_{\mathrm{o}}+\mathrm{a}\right)$, em que $\mathrm{T}_{1}$ : nova tarifa, $\mathrm{T}_{\mathrm{o}}$ : tarifa vigente, a: tarifa máxima projetada. Essa formulação é interessante porque implicitamente considera o padrão de decaimento tarifário da pauta em análise. Por hora, só temos o valor da proposta norte-americana construído nesse contexto.
} 
- tarifa ad valorem (ou seu equivalente no caso da presença de direitos específicos) que superem 12\%, segundo a Unctad, citada em Brasil (2001);

- tarifas iguais ou superiores a três vezes a tarifa média simples nos países desenvolvidos, de acordo com a definição do International Monetary Fund (IMF) \& World Bank (WB) (2001).

Ainda que não exista um consenso sobre o nível que identifica um pico tarifário, segundo Bouët et al. (2001), quanto maior o desvio padrão de um grupo de tarifas maior a distorção econômica provocada pelo mesmo. Isto é, a presença de picos tarifários traduz um dos elementos de distorção produzida pela pauta tarifária em análise.

Empiricamente, Hoekman et al. (2001) calcularam o número de tarifas maiores que $15 \%$ para os produtos agrícolas e não agrícolas dos maiores mercados consumidores globais, notando-se que em relação a Canadá, EUA e Japão, há uma maior proporção de picos tarifários agrícolas na pauta de tarifas da União Européia.

Tabela 12. Picos tarifários para os maiores mercados agrícolas.

\begin{tabular}{lcccc}
\hline \multicolumn{1}{c}{ Número de picos $(>15 \%)^{1}$} & EUA & UE & Japão & Canadá \\
\hline Total de produtos da pauta & 311 & 317 & 233 & 732 \\
Produtos agrícolas da pauta & 48 & 290 & 178 & 85 \\
$\%$ dos agrícolas no total & $15,4 \%$ & $91,5 \%$ & $76,4 \%$ & $11,6 \%$ \\
\hline
\end{tabular}

Fonte: Hoekman et al. (2001), citado em IMF \& WB (2001)

${ }^{1}$ Refere-se ao parceiro comercial descrito no conceito NMF.

Em específico no que se relaciona à pauta tarifária agrícola consolidada pela União Européia no conceito NMF, Gibson et al. (2001) obtiveram os seguintes valores estimados: 
Tabela 13. Megatarifas registradas na pauta agrícola consolidada da UE no conceito NMF.

\begin{tabular}{lc}
\hline \multicolumn{1}{c}{ Descrição do produto } & Megatarifas $^{1}$ \\
\hline Todos os produtos & 141 \\
Grãos & 2 \\
Produtos à base de grãos & 2 \\
Grãos para ração & 9 \\
Óleos vegetais & 1 \\
Óleos e gorduras & 1 \\
Outras carnes frescas ou congeladas & 29 \\
Carne fresca (bovina, suína ou de aves) & 6 \\
Carne congelada (bovina, suína ou de aves) & 24 \\
Preparados de carne & 7 \\
Lácteos & 41 \\
Frutas frescas & 1 \\
Sucos de frutas & 3 \\
Vegetais frescos & 3 \\
Outros vegetais congelados ou preparados & 2 \\
Preparações de vegetais & 2 \\
Açúcar de beterraba & 1 \\
Confeitarias e guloseimas & 2 \\
\hline
\end{tabular}

Fonte: Gibson et al. (2001), citados em UKFG (2002a)

${ }^{1}$ Os autores definem pico tarifário como tarifas ad valorem (ou suas EAV's) iguais ou superiores a $100 \%$.

Já o tabalho da WTO (2002b) afirma que picos tarifários (3 vezes a média simples) continuam evidentes para carnes, lácteos, produtos cereais processados e não processados, frutas processadas e legumes, relativamente à pauta tarifária agrícola e agrícola processada da UE. Esse mesmo estudo também destaca a grande amplitude entre tarifas mínima e máxima para a agricultura (de $0 \%$ a 470,8\%) vis a vis a distância entre as tarifas mínima e máxima de produtos não agrícolas (0\% a 36,6\%). 
Ainda retomando-se o trabalho de IMF \& WB (2001), ali, tem-se explicitamente que na UE os picos tarifários estão concentrados em agricultura e em produtos alimentícios, particularmente lácteos, legumes, café, chá, cereais, açúcar, cacau e tabaco, embora também presente em calçados.

Bouët (2000) ressalta que os picos tarifários no caso da UE concentram-se justamente em itens da indústria agroalimentar, enquanto Bureau (2002) elenca uma série de itens agrícolas ou de processados agrícolas considerados protegidos pela tarifa consolidada da UE. Segundo tal trabalho, os grupos de produtos agrícolas mais afetados pelo fenômeno são: carnes e miudezas, leite e laticínios, frutas, cereais, óleos animais ou vegetais, e açúcares e confeitaria.

De certa forma, em relação a todos esses valores reportados, vale o raciocínio de Marsch \& Tarditi (2003). Esses autores entendem que, no processo de tarificação promovido pela UE em resposta aos compromissos do Acordo Agrícola, muitas tarifas agrícolas ou de agrícolas processados foram (re)fixadas em níveis elevados, concentrando-se as reduções nos bens de menor importância para a agricultura doméstica.

\subsubsection{Tarifas sazonais e sistema de preços de entrada}

De acordo com Gibson et al. (2001), a estrutura tarifária agrícola eurocomunitária está entre as mais complexas do mundo, abrangendo taxas que variam dentro de um mesmo exercício e que podem ser impostas com base em complexas relações técnicas, de modo a se produzir combinações de tarifas (específica e ad valorem) variáveis no transcurso do ano.

Conforme USDA (1998), isso ocorre porque, durante a Rodada do Uruguai, foi permitido à UE aplicar tarifas mais altas sobre as importações de produtos hortícolas com preço abaixo de um certo preço de entrada. Isso possibilita isolar os mercados agrícolas domésticos dos preços mundiais e discriminar contra as importações mais baratas naqueles produtos. É o caso das chamadas tarifas sazonais. 
No contexto da UE, as tarifas sazonais concentram-se nos itens dos capítulos sete e oito do sistema harmonizado. Segundo a própria OMC, citada em Brasil (2001), a tarifa sazonal tem contemplado $11 \%$ dos itens da estrutura tarifária da UE, concentrando-se sobre frutas, vegetais e flores, e guarnecendo produtores locais na época da safra.

WTO (2000) assinala que, no tocante à UE, as condições de acesso em produtos agrícolas são afetadas pelo funcionamento da PAC e que outras complexidades no regime aduaneiro para produtos agrícolas produzidos na Comunidade incluem impostos específicos, com base em componentes ou sazonalidade, ou ainda no contexto dos preços de entrada.

O preço de entrada é definido pela regulação comunitária conforme Comissão Européia (2002a). Ele pode ser o preço $F O B$ acrescido de custos de seguro e fretes até a chegada a um dos portos comunitários. Ele também pode ser o valor do produto na alfândega do país membro da UE. Ou ainda um valor médio de importação,

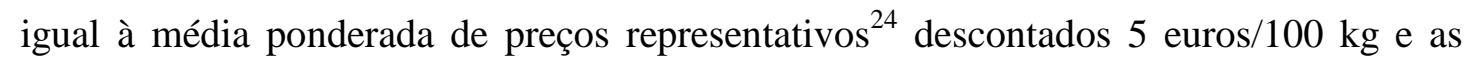
tarifas ad valorem.

De fato, cada caso assumirá uma dessas três definições e dependerá da natureza da operação de importação e do produto em questão, bem como da identificação de margem entre os respectivos atacadistas e varejistas europeus ${ }^{25}$.

Teoricamente, veja-se a figura abaixo quanto ao funcionamento do mecanismo de tarifação sob sistema de preços de entrada.

\footnotetext{
${ }^{24}$ Refere-se a produtos importados de terceiros países que sejam vendidos a mercados importadores representativos na UE (31 grandes cidades ou regiões metropolitanas do bloco) ou a preços registrados em outros mercados da UE quando da ocorrência de grandes quantidades importadas. A construção dessas médias leva em conta cotações diárias e por origem do produto.

${ }^{25}$ Somente com essas informações percebe-se que um estudo exaustivo do mecanismo foge ao escopo desse texto. Para maiores detalhamentos ver a base de textos legais da UE (CONSLEG), em especial as regulações 3223/94, 553/95, 1306/95, 1363/95, 1740/95, 2933/95, 1890/96, 2375/96, 1498/98, 453/02, e 1947/02.
} 
T.E. (euro/Kg)

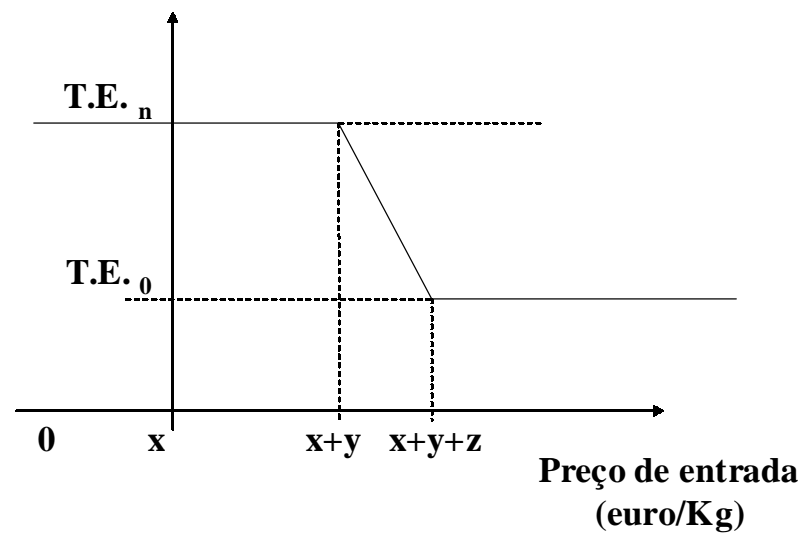

Figura 6 - Tarifa específica sob sazonalidade.

À medida que o preço de entrada se reduz no sentido de $(\mathrm{x}+\mathrm{y})$, cresce a tarifa específica cobrada no acesso ao mercado comunitário. Note-se também que vigoram uma tarifa específica mínima bem como uma tarifa específica máxima. Em geral, ao longo desse processo, vigora também uma tarifa ad valorem constante.

Em termos práticos, Grethe \& Tangermann (1998) e Cioffi \& Dell'Aquila (2003) afirmam que o funcionamento desse sistema resulta em tarifas proibitivas quando de importações com preços inferiores a $92 \%$ do respectivo preço de entrada.

\subsubsection{Mecanismo de gatilhos}

O chamado mecanismo de gatilhos enquadra-se nas medidas de salvaguardas especiais, originárias em agricultura do Acordo Agrícola da Rodada do Uruguai ${ }^{26}$. As salvaguardas especiais caracterizam-se como um mecanismo de exceção, implicando proteção de mercado, permitida nos casos em que o volume de importações seja considerado excessivo ou o preço de ingresso dessas importações tido como muito baixo e prejudicial à produção doméstica.

\footnotetext{
${ }^{26}$ Esse mecanismo é permitido com base no Artigo V do Acordo Agrícola, acerca das provisões de salvaguardas especiais.
} 
Thorstensen (1999) apresenta as condições para a imposição de salvaguardas:

- caso o volume de importações do produto entrando no território aduaneiro do membro que fez a concessão, em qualquer ano, exceder um volume de gatilho (trigger level) determinado, estabelecido em função das oportunidades existentes no mercado;

- caso o preço de importação do produto, com base no preço CIF. em moeda doméstica seja inferior ao preço de gatilho (trigger price) estabelecido pela média dos preços de referência do produto de 1986 a 1988.

Em relação às medidas de salvaguarda, dois regimes aplicam-se aos produtos agrícolas: o mecanismo de salvaguardas especiais e as provisões de salvaguardas regulares. Os mecanismos de gatilhos enquadram-se no primeiro caso. Além disso, WTO (2002b) afirma que os impostos adicionais desse instrumento não podem ser aplicados às importações dentro das quotas tarifárias.

Do ponto de vista efetivo, no caso da União Européia qualquer membro comunitário pode invocar as medidas de salvaguarda, as quais podem incluir restrições quantitativas.

Pelo Acordo Agrícola, qualquer imposto adicional colocado sob a hipótese de gatilho de volume não poderá exceder 1/3 do nível de tributação já presente na pauta tarifária para aquele item específico no ano em que o gatilho é acionado, somente vigorando até o final desse mesmo exercício. Ademais, o volume (a partir do qual vigora o gatilho) é referido pelo conceito de oportunidades de mercado, definidas como um percentual do consumo doméstico correspondente durante o período dos três anos imediatamente precedentes para os quais se tenham dados disponíveis. 
Esquematicamente têm-se os três níveis-base de gatilho:

i) quando as oportunidades de acesso a mercado (como acima definidas) para um produto forem inferiores ou iguais a 10\%, o nível-base de gatilho será de $125 \%$

ii) quando as oportunidades de acesso a mercado para um produto forem inferiores ou iguais a $30 \%$ e maiores que $10 \%$, o nível-base de gatilho será de $110 \%$

iii) quando as oportunidades de acesso a mercado para um produto forem maiores que $30 \%$, o nível-base de gatilho será de $105 \%$;

Como tabela exemplificadora tem-se:

Tabela 14. Gatilho de volume.

\begin{tabular}{lc}
\hline Acesso a mercado (A) & Nível de acionamento de gatilho \\
\hline $\mathrm{A} \leq 10 \%$ & $125 \%$ de A \\
$10 \%<\mathrm{A} \leq 30 \%$ & $110 \%$ de A \\
$\mathrm{A}>30 \%$ & $105 \%$ de A \\
\hline
\end{tabular}

Fonte: elaborado pelo autor com base no Acordo Agrícola.

Nota: onde o consumo doméstico não seja levado em conta o nível-base de gatilho será o do item i), com acesso de $10 \%$ ou menos do consumo doméstico.

Qualitativamente o que se nota é que quanto maiores forem as oportunidades de acesso, menores os níveis-piso que acionam o respectivo gatilho na forma de um imposto adicional. 
Outra pergunta que se coloca é: quando o imposto adicional pode ser empregado? Quando o volume de importações do bem for maior que um certo volume $\mathrm{V}$, no que:

$$
V=(x \cdot m)+y
$$

sendo:

$x$ - nível-base de gatilho: definido em cada caso acima;

$m$ - quantidade média de importações nos três anos anteriores de dados disponíveis;

$y$ - mudança no volume total de consumo doméstico do bem no ano mais recente disponível vis a vis o ano que lhe é anterior.

Em paralelo, para o gatilho de preços, vale um procedimento de cálculo do imposto adicional contabilizando a diferença entre o preço $C I F$ de importação, expresso em moeda doméstica e o preço de gatilho (que aciona o imposto extra), nos seguintes termos:

i) se essa diferença for menor ou igual a $10 \%$ do preço de gatilho, nenhum adicional de imposto será exercido;

ii) se essa diferença estiver entre $10 \%$ e $40 \%$ do preço de gatilho, o adicional de imposto será de $30 \%$ do montante em que a diferença tenha excedido os $10 \%$ do preço de gatilho;

iii) quando a citada diferença estiver entre $40 \%$ e $60 \%$ do preço de gatilho, o adicional de imposto será de 50\% do montante em que a diferença exceder os $40 \%$ do preço de gatilho, mais o acréscimo integral referente ao item ii); 
iv) se essa diferença estiver entre $60 \%$ e $75 \%$ do preço de gatilho, o imposto adicional será de $70 \%$ do montante em que a diferença exceder os $60 \%$ do preço de gatilho, mais os acréscimos integrais referentes aos itens ii) e iii);

v) por fim, se a citada diferença estiver além de $75 \%$ do preço de gatilho, o adicional de imposto será de $90 \%$ do montante em que a diferença tenha excedido os $75 \%$ do preço de gatilho, mais os acréscimos integrais referentes aos itens ii), iii) e iv).

A tabela abaixo é ilustrativa e evidencia o caráter cumulativo do mecanismo.

Tabela 15. Gatilho de preço.

\begin{tabular}{lcc}
\hline Diferença (D) & Adicional de imposto no nível & Adicional de imposto acumulado \\
\hline $\mathrm{D} \leq 10 \%$ do p.gat. & $0 \%$ & $0 \%$ \\
$10 \%$ do p.gat. $\angle \mathrm{D} \leq 40 \%$ do p.gat. & $30 \% *(\mathrm{D}-10 \%$ do p.gat. $)=\mathrm{A}$ & $=\mathrm{A}$ \\
$40 \%$ do p.gat. $\angle \mathrm{D} \leq 60 \%$ do p.gat. & $50 \% *(\mathrm{D}-40 \%$ do p.gat. $)=\mathrm{B}$ & $\mathrm{A}+50 \% *(\mathrm{D}-40 \%$ do p.gat. $)$ \\
$60 \%$ do p.gat. $<\mathrm{D} \leq 75 \%$ do p.gat. & $70 \% *(\mathrm{D}-60 \%$ do p.gat. $)=\mathrm{C}$ & $\mathrm{A}+\mathrm{B}+70 \% *(\mathrm{D}-60 \%$ do p.gat. $)$ \\
$\mathrm{D}>75 \%$ do p.gat. & $90 \% *(\mathrm{D}-75 \%$ do p.gat. $)=\mathrm{E}$ & $\mathrm{A}+\mathrm{B}+\mathrm{C}+90 \% *(\mathrm{D}-75 \%$ do p.gat. $)$ \\
\hline
\end{tabular}

Fonte: elaborado pelo autor com base no Acordo Agrícola.

Notas: $\mathrm{D}=$ diferença entre preço $C I F$ e preço de gatilho;

p. gat. $=$ preço de gatilho . Ambos os preços em moeda do país importador.

Para USDA (1998), a introdução da cláusula de salvaguardas especiais no Acordo Agrícola representou uma regra de exceção às tarifas consolidadas e foi rapidamente incorporada como mecanismo de defesa comercial pela União Européia.

Sob tal aspecto, Brasil (2001) reporta o uso de salvaguardas especiais como instrumento não tarifário, mesmo que o mecanismo de acionamento de gatilhos implique em majoração da tarifa. Além disso, o uso de salvaguardas especiais na relação de exportações agrícolas Brasil-UE tende a ser usado em conjunto com a tarificação sazonal, vez que conforme instituído pela UE em 1996, no caso da maçã, a salvaguarda 
incide todo o ano; para limões, de junho a dezembro; e para laranja, tangerina e uva diretamente condicionadas à safra da UE.

Com base nesses elementos, pode-se dizer que a cláusula de salvaguardas efetivamente dilui os compromissos assumidos no processo de tarificação. Em verdade, é possível argumentar que tal mecanismo é funcional para grupos que defendem seus interesses por meio de brechas e cláusulas de exceção no sistema multilateral de comércio.

Conforme Bureau (2002), os mecanismos de salvaguardas especiais são muito mais fáceis de serem invocados que os mecanismos de salvaguardas permitidas pelo Artigo XIX do Gatt 1994, dado que as salvaguardas especiais podem ser acionadas sem a comprovação do dano motivador. Segundo o mesmo autor, a cláusula de salvaguardas especiais cria uma significativa proteção adicional às tarifas, sendo notável que com o acionamento da cláusula de salvaguardas especiais, os preços de chegada sujeitos a sobretaxa são sensivelmente maiores que os respectivos preços de chegada consolidados no processo de tarificação. Por exemplo:

- o preço de gatilho para manteiga foi estabelecido em 2.483 euros/t., enquanto que a tarifa específica resultante dos compromissos assumidos na Rodada do Uruguai foi de 943 euros/t;

- no açúcar branco os respectivos valores foram 531 euros/t. e 193 euros/t.

\subsection{Quotas tarifárias}

O sistema de quotas tarifárias é um subproduto do processo negociador da Rodada do Uruguai. Ele é definido por alguns autores como uma barreira não tarifária. Contudo, essa conceituação não é universal, pois há estudos que enquadram a quota tarifária na categoria das barreiras tarifárias. Em todo o caso, a avaliação do real acesso 
ao mercado de bens agrícolas e agrícolas processados da UE inclui a mensuração do mecanismo de quotas tarifárias.

Quando da Rodada do Uruguai as quotas surgiram como um subproduto do processo de conversão das medidas não tarifárias em tarifas que se mostrariam proibitivas. Em tese, as quotas tarifárias foram projetadas para garantir acesso mínimo aos mercados, mas mostraram-se instrumento pouco democrático para tais fins, seja em termos da transparência dos métodos de alocação das mesmas seja quanto aos volumes negociados nas tarifas intraquota relativamente ao respectivo mercado doméstico.

A quota tarifária nada mais é do que um escalonamento tarifário de restrição ao acesso, composto de dois níveis de tarifa: até um certo volume limitado de importação cobra-se uma tarifa, após esse contingente as importações adicionais sofrem uma segunda - e mais alta - tarifa. Conforme Skully (2001), quando essa tarifa mais alta torna as importações não lucrativas a quota tarifária funciona como uma quota pura de importação ${ }^{27}$.

Entretanto, para surpresa, as quotas tarifárias definidas no âmbito do Acordo Agrícola da Rodada do Uruguai foram adotadas como "solução de acesso" para converter quotas puras de importação em restrições tarifárias. O objetivo implícito seria a promoção de acesso mínimo aos mercados e, no caso de acesso já preexistente, sustentar ao menos o acesso corrente. Nesse momento, foi permitido à União Européia construir suas quotas tarifárias.

\subsubsection{A economia política das quotas tarifárias}

Em linhas gerais, dois critérios são usados para aferir a eficiência econômica do método de locação de quotas usado pelo país que as impõe. São eles: o nível de preenchimento da quota e a não discriminação.

\footnotetext{
${ }^{27}$ A quota pura de importação significa o estabelecimento de um teto quantitativo para as importações.
} 
Por nível de preenchimento da quota, entende-se que o método de locação das quotas não deve, per si, inibir a ocorrência de importações. De fato, tal argumento pode parecer inócuo pois em certos momentos o nível de preenchimento da quota depende mais das condições de mercado (doméstico e mundial) e dos patamares (efetivos ou não) das tarifas intraquota e extraquota que propriamente do método de alocação sob o qual os volumes daquela específica quota foram distribuídos ${ }^{28}$.

Já o critério da não discriminação advoga que as importações devem se dar em função da eficiência econômica relativa dos ofertantes daquele bem, sem favorecimentos pontuais a certo país exportador. A esse respeito, Skully (2001) afirma que alguns métodos administrativos apresentam um maior risco de discriminação do que outros.

Do ponto de vista da economia política, a administração das quotas pode ter um impacto direto tanto sobre os fluxos de comércio como sobre a apropriação das rendas da quota originárias de sua implementação. Isso faz dos métodos de administração das quotas tarifárias uma questão polêmica, ainda a ser melhor estudada.

Em verdade, a transparência com que um sistema de quotas tarifárias é administrado é central para que as mesmas tenham seu caráter anticomércio minimizado. UKFG (2002a) sustenta que:

“... desde o Acordo Agrícola da Rodada do Uruguai, os países em desenvolvimento têm tido pouco sucesso em acessar as quotas tarifárias abertas durante o Acordo. Exportadores dos países em desenvolvimento pesquisados pela FAO alegaram carência de informação sobre oportunidades de exportação sob

\footnotetext{
28 Aliás, o IATRC (2001) argumenta que um baixo nível de preenchimento da quota não implica necessariamente ineficiência e que uma taxa de preenchimento de $100 \%$ ou mais não necessariamente implica eficiência. Entretanto, ineficiência e custos de transação impostos pelos esquemas de alocação podem resultar em subpreenchimento da quota.
} 
essa medida de acesso. A confusão era ampla e generalizada considerando-se sistemas de locação e administração das quotas tarifárias".

Conforme o International Agricultural Trade Research Consortium (IATRC) (2001), todos os países signatários do Acordo Agrícola concordaram em manter o acesso mínimo de 3\% do consumo doméstico (sendo base a média anual do período 19861988), subindo para 5\% em 2000. Efetivamente, porém, em muitos países as quotas tarifárias têm sido usadas para manter fluxos de importações tradicionais sem resultar em aumentos do comércio, não sendo raros os casos de quotas tarifárias alocadas a países específicos, em demérito dos exportadores mais competitivos naquele produto.

Embora as TRQ's (do inglês Tariff-Rate Quotas) tenham sido discutidas nas chamadas Modalidades da OMC durante os compromissos da Rodada do Uruguai, elas não foram incorporadas aos documentos finais, o que na prática deixou a operacionalização das mesmas ao escrutínio de cada país. Isso propiciou uma série de distorções da idéia original das quotas tarifárias, ressaltando-se:

- muitos países calcularam suas TRQ's por métodos que nem sempre representam 5\% do consumo doméstico;

- institucionalizaram-se tarifas proibitivas para importações além da quota;

- por vezes são utilizadas classificações estatísticas não-padronizadas, protegendo-se certo mercado pelo nível ou forma de detalhamento do produto sob análise ou alocando-se toda a quota para produtos de alto grau de detalhamento e especificidade; 
- há problemas de transparência, regularidade e harmonização dos procedimentos de notificação e operação das quotas criadas, sendo no mínimo possível burlarem-se os compromissos assumidos na área de acesso a mercados através dos procedimentos de cálculo.

Essas brechas de regulamentação oriundas desde o Acordo Agrícola na área de quotas tarifárias agrícolas são parte do próprio caráter contraditório da disciplina no tema: por um lado, defende-se o uso de tarifas e não discriminação no comércio, mas em paralelo permitem-se as $T R Q$ 's.

Esse ponto em particular tem gerado desequilíbrios quando da distribuição das quotas tarifárias. Embora os países beneficiários possam mudar de ano para ano no momento de alocação das quotas, uma vez que certo exportador é agraciado com a concessão de um share no volume total da quota ele agressivamente defenderá o "seu" exercício naquela relação de comércio. Desse ponto de vista, a alocação de volumes com base em fluxos ou relações históricas de comércio reduz a dinâmica de mercado, segundo a qual, os mais competitivos exerceriam maiores fluxos de vendas.

De fato, como as regulações estabelecidas na Rodada do Uruguai em nível de quotas tarifárias são abertas, diversas complexidades podem ser introduzidas pelo país que estrutura um esquema de quotas tarifárias. Por exemplo, conforme WTO (1997), citado em IATRC (2001), na disputa da banana, o esquema de licenciamento de importações da UE foi considerado 'altamente complexo' para o produto importado oriundo da América Latina.

Essa pouca transparência também é denominada por muitos autores como "quotificação suja", face à arbitrariedade usada na escolha dos períodos-base, o uso de importações ora absolutas ora líquidas, ou mesmo o cálculo de níveis de consumo 
levando-se em conta elevada agregação dos bens ${ }^{29}$. Está claro que cada país optou pela metodologia de cálculo mais alinhada à diretriz de sua política comercial em agricultura.

Outro ponto bastante criticado no funcionamento do atual sistema de quotas tarifárias em agricultura é a possibilidade de se constatar subpreenchimento (formal) das mesmas com importações paralelas contabilizadas fora da quota ou em acordo preferencial, para aquele mesmo item objeto da relação comercial, além das próprias quotas preferenciais e de importações autônomas (não notificadas) ${ }^{30}$. Essas imperfeições passam tanto pelas entidades agraciadas com o direito de exercer a quota no mercado importador como pelos países que recebem o direito de exportar para tal mercado.

Operacionalmente, o método de locação de uma quota tarifária é fator de influência (mas não seu responsável exclusivo) na posição da curva de excesso de demanda ED (mercado importador). A curva ED é o resultado da posição das curvas de oferta e demanda domésticas naquele bem.

A partir da figura abaixo, se $\mathrm{P}_{1}$ é o preço mundial e $\mathrm{S}_{2}$ a oferta doméstica daquele bem, dada a curva $\mathrm{D}$, não há importações. Porém, em muitos casos, a produção doméstica pode não ser competitiva em níveis mundiais $\left(\mathrm{S}_{1}\right.$, por exemplo), sendo $\mathrm{P}_{2} \mathrm{um}$ preço com tarifa intraquota e $\mathrm{P}_{3}$ um preço com tarifa extraquota. Note que se $\mathrm{P}_{3}=\mathrm{P}^{*}$, anula-se o excesso de demanda naquele mercado doméstico.

\footnotetext{
${ }^{29}$ Por tabela, os efeitos de liberalização comercial com a criação de quotas tarifárias agrícolas variaram bastante e tornaram-se difíceis de serem calculados por meio de uma metodologia universal. Isso, no status quo presente das quotas tarifárias, traduz-se no fato de que a liberalização comercial via redução de tarifas tem um efeito diferente daquele oriundo de um aumento no volume da quota, requerendo-se, portanto, uma avaliação país a país, produto a produto.

${ }^{30}$ Isso torna os cálculos de preenchimento das quotas divulgados pela OMC suscetíveis às diferentes classificações que os países signatários conferem às suas importações, tanto as notificadas como as efetivamente realizadas.
} 


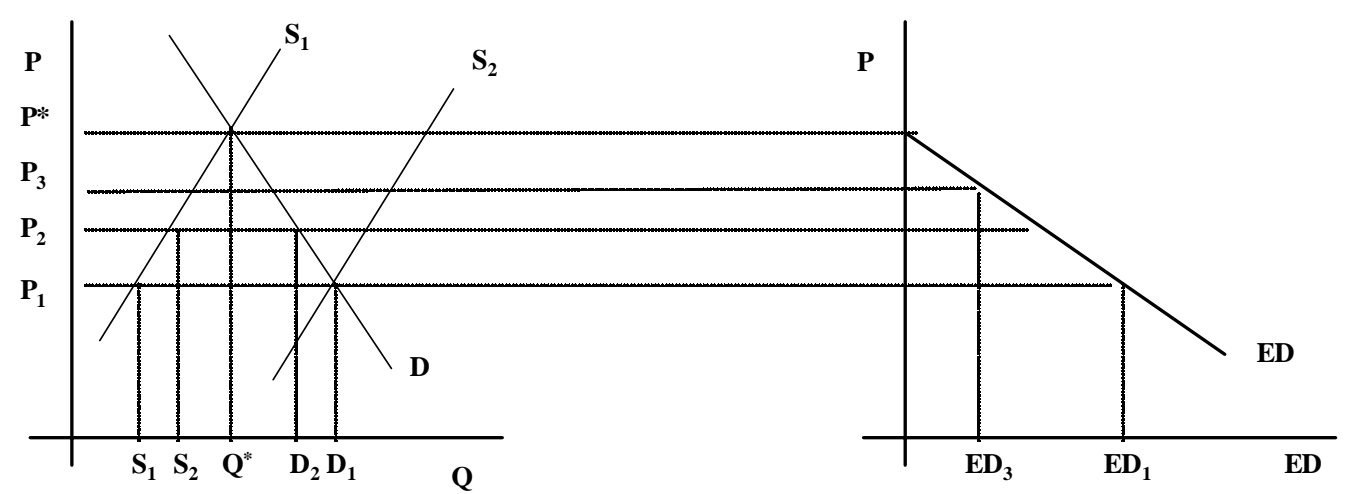

Figura 7 - Formação da curva ED.

Fonte: adaptado de Skully (2001)

Aproveitando-se do exemplo posto em Skully (2001), assume-se uma curva de ED tradicional e uma curva de oferta de exportações infinitamente elástica ${ }^{31}$. Essa curva de oferta de exportações terá dois níveis face à quota tarifária, justamente pela existência de um volume limitado de importações que podem acessar aquele mercado sob as condições da tarifa intraquota. Volumes adicionais vêem-se submetidos à tarifa extraquota, usualmente proibitiva, podendo-se destacar quatro pontos extremos a partir da próxima figura.

\footnotetext{
${ }^{31}$ Para alguns produtos agrícolas de interesse do Brasil, a curva de oferta de exportações agrícolas para o mercado consumidor euro-comunitário seria, mais provavelmente, positivamente inclinada.
} 


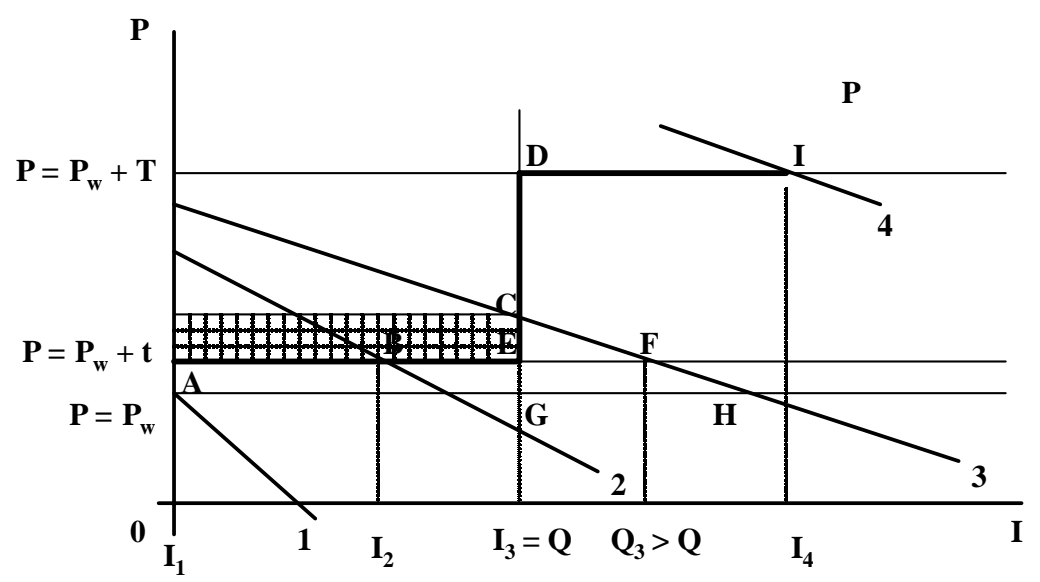

Figura 8 - Quotas tarifárias afetando demanda por importações.

Fonte: adaptado de Skully (2001)

Nota: a área pontilhada corresponde à renda da quota quando vale o excesso de demanda dado pela curva 3 .

Sendo t a tarifa intraquota, $\mathrm{T}$ a tarifa extraquota e as curvas " 1 " a " 4 " as curvas de excesso de demanda, destacam-se os seguintes pontos representativos:

- ponto A, em que $\mathrm{I}_{1}=0$. $\mathrm{O}$ excesso de demanda por importações é insuficiente para que ocorram importações, mesmo sob livre comércio com preços domésticos iguais aos preços mundiais;

- ponto $\mathrm{B}, \mathrm{I}_{2}<\mathrm{Q}$ (volume limite intraquota). O excesso relativo de demanda já aciona a tarifa intraquota, mas o volume inicial da quota ainda não é estritamente limitante;

- ponto $\mathrm{C}, \mathrm{I}_{3}=\mathrm{Q}$. Um deslocamento de ED à direita ao longo do eixo vertical dado pela quota $\mathrm{Q}$ fará as rendas da quota variarem em função da exata posição do ponto $\mathrm{C}$ entre $\left(\mathrm{P}_{\mathrm{w}}+\mathrm{t}\right)$ e $\left(\mathrm{P}_{\mathrm{w}}+\mathrm{T}\right)$; 
- ponto $\mathrm{D}, \mathrm{I}_{4}>\mathrm{Q}$. Em existindo excesso de demanda por importações à direita do ponto D já passa a ser operante a tarifa extraquota e a renda máxima da quota já foi extraída daquela quota tarifária;

Algebricamente, a renda da quota é dada por $\left[(\mathrm{P}+\mathrm{T})-(\mathrm{P}+\mathrm{t})^{*} \mathrm{Q}\right]$. Além disso, percebe-se que as rendas são o resultado econômico puro de se racionar uma oferta limitada (Q, por exemplo) para um excesso de demanda de Q', Q' > Q. Logo, nos pontos $\mathrm{C}$ e $\mathrm{D}$ (no limite), a arrecadação do Governo é $\mathrm{t}^{*} \mathrm{Q}$, enquanto que a renda da quota é que é variável. Os fenômenos discutidos nos pontos C e D baseiam-se também no fato de que a renda da quota é exatamente função da diferença entre o preço vigente - dado pela interseção das curvas ED e de oferta de exportações - e o preço mundial acrescido da tarifa intraquota ${ }^{32}$. De fato, o agente ao qual é dado o direito de exercer a tarifa extraquota é que auferirá a renda da mesma.

Logo, a disposição política e/ou econômica em se realizar as rendas da quota e a posição relativa da curva ED são os dois ${ }^{33}$ elementos por detrás do posicionamento final de um mercado afetado por quotas tarifárias. Mais uma vez citando Skully (2001):

"Quanto mais sensíveis politicamente as importações de um bem maior a probabilidade de que os métodos de alocação da quota tarifária sejam discricionários, isto é, alocação para monopólio estatal de comércio ou para grupos de produtores nacionais".

\footnotetext{
${ }^{32}$ Observe-se que para muitos países a tarifa intraquota assumida é a própria tarifa aplicada.

${ }^{33}$ IATRC (2001), oportunamente, ressalta a importância em não se desconsiderar as variáveis do lado da oferta: "Por exemplo, aumentos nos custos de importação (devido a um aumento nos preços mundiais) também podem tornar as tarifas intraquota ou extraquota mais ou menos efetivas."
} 
Enfim, é também de se destacar que o padrão de distribuição das rendas (sob esse ou aquele método e com quais beneficiários diretos) também afeta o padrão de distribuição do comércio, ou seja, que país fornecedor daquele bem tem direito a ocupar a quota e em qual proporção.

Isso posto, cumpre uma apresentação dos métodos de alocação de quotas tarifárias.

\subsubsection{Tarifa aplicada}

Segundo Cunha Filho (2004), nessa modalidade a quota foi estruturada, mas apenas com tarifa intraquota. Assim, não há um limite a partir do qual vigore uma segunda e mais alta tarifa. Sem a distribuição de direitos de importação, não há criação de renda adicional e a única medida restritiva é a tarifa intraquota.

\subsubsection{Leilão}

O uso do leilão como método de alocação de quotas tarifárias corresponde à introdução de um mecanismo concorrencial para a distribuição das mesmas. Aberto o leilão e vigente a quota tarifária $Q$, se se acredita num $E D$ suficientemente forte para que vigore o preço $\left(\mathrm{P}_{\mathrm{w}}+\mathrm{T}\right)$ - vide figura precedente - então o sistema de quotas permite a compra por $\mathrm{P}$.

Nesse processo, fornecedores eficientes apostarão (T-t) pelo direito da quota, enquanto fornecedores menos eficientes apostarão menos que o equivalente a esse valor monetário. Isso fará com que a discriminação ocorra em favor dos exportadores de menor custo, caso não haja processos paralelos de intervenção. Nesse contexto, o não preenchimento da quota (underfill) e desvios na distribuição de comércio são menos prováveis.

Porém, na mecânica descrita, o processo requer um grande número de exportadores (competidores no leilão) ou um grande volume negociado na quota. Sem essa liquidez, segundo Skully (2001), condições específicas do bem sob análise e dos 
países envolvidos podem tornar outros métodos de locação da quota preferíveis. Apesar de seu apelo econômico, os leilões são pouco utilizados, principalmente porque os governos têm preferência por certos países e/ou empresas na hora de promover a alocação das quotas tarifárias.

\subsubsection{Licença sob demanda}

Antes de ser aberto o período de vigência da quota tarifária, potenciais importadores são convidados a registrar seus pedidos de licença. Uma vez que tal período já esteja em transcurso, a quota é dividida, respeitando-se a proporção de pedidos cabível a cada importador até então solicitante. Neste ponto, as licenças são concedidas para unidades que serão importadas pagando-se $(\mathrm{P}+\mathrm{t})$.

Esse regime tende a causar uma grande incerteza em termos de que volumes serão de fato disponíveis a cada importador porque não se conhece o número nem o volume total de pedidos dos outros solicitantes. Por um lado, isso pode levar os solicitantes a superestimarem seus pedidos, resultando em quantidades não econômicas alocadas a cada solicitante.

De outra parte, torna-se difícil avaliar se as exportações àquele mercado serão de fato rentáveis, pois se o volume de licenças obtidas ao fim do processo for muito pequeno, os embarques podem também tornar-se antieconômicos ao elevarem o custo fixo de bens que poderão eventualmente ser vendidos por $(\mathrm{P}+\mathrm{T})$ no mercado de produto final $^{34}$.

Outro ponto de incerteza a considerar é que nesse método de locação das quotas é preciso assumir uma distribuição de probabilidade quanto a quem atenderá primeiro às exigências para preenchimento da quota.

\footnotetext{
${ }^{34}$ Um modelo algébrico (ainda bastante geral e não exaustivo) sobre o subpreenchimento de quotas no regime de licença sob demanda pode ser encontrado no apêndice de Skully (2001)
} 
Dada a questão da incerteza discutida nos dois parágrafos acima, o grupo de ofertantes finais na quota pode não ser composto majoritariamente por importadores de baixo custo, mas sim por importadores de baixo custo de transporte e/ou que superestimaram seus pedidos de licenças de importação.

\subsubsection{Primeiro a chegar, primeiro a servir-se}

Como o próprio nome aponta, esse regime de locação de quota tarifária propicia que os importadores/exportadores melhor informados sobre o período de abertura e condições de vigência da quota usufruam da tarifa intraquota. Volumes posteriores serão taxados com a tarifa extraquota.

Quanto ao preenchimento da quota, esse sistema tende a conduzir a importações abaixo do volume limite da quota, pois muitos países e importadores ainda carecem de informação prontamente disponível sobre os níveis de preenchimento de uma dada quota tarifária. Ademais, há também os custos de estocagem (até o próximo período de abertura da quota) e embarque que correm por conta do agente interessado.

Quanto aos efeitos desse regime sobre a distribuição do comércio, seria de se esperar que os candidatos mais disponíveis (os primeiros da fila) a uma certa quota tarifária fossem os produtores mais eficientes daquele bem ou os importadores ligados a tais fornecedores competitivos. Todavia, os problemas de precisão de informação ainda recorrentes nas transações entre muitos parceiros comerciais são um fato na realidade do comércio internacional e podem resultar na substituição de exportadores competitivos por outros relativamente menos eficientes.

Tanto nesse caso como no das licenças sob demanda, o que se percebe é a fragilidade da hipótese de informação simétrica e prontamente disponível, quase um axioma dos modelos de concorrência perfeita nos livros-textos de economia. Mas a realidade é um pouco mais complexa. 


\subsubsection{Alocação com base em fornecimento histórico ${ }^{35}$}

O regime de alocação de quotas com base em volumes históricos de comércio pode ser considerado uma espécie de loteria com um só lançar dos dados, geralmente em detrimento dos países com mais baixo custo de exportação que acabam por não compor o preenchimento da quota. Uma vez alocada a quota de certo produto a um dado fornecedor, o regime de concessão e o beneficiário raramente mudam, mesmo quando de alterações nas condições de mercado do produto em questão.

Essas características tornam o regime de quotas tarifárias assim definido claramente discriminatório, vez que as realocações são pouco freqüentes. Além disso, o governo importador de regra aloca os maiores volumes de quota a parceiros comerciais já tradicionais. Com tudo isso, os volumes pertinentes à referida quota tornam-se reféns de acordos comerciais estabelecidos a priori ou em implementação.

Curiosamente, muitas dessas quotas tarifárias não são preenchidas. Pode-se argumentar que a característica quase que vitalícia do beneficiário da quota tende a conduzir a não preenchimentos da mesma porque a alocação da quota sob tal regime é insensível a alterações nas eficiências relativas dos potenciais ofertantes.

\subsubsection{Quotas alocadas a monopólios estatais de comércio ou a grupos de produtores nacionais}

Nesse regime a responsabilidade de se permitir que dado país ocupe a quota é delegada pelas autoridades a grupos ou organizações específicas. Sob tal quadro, pode ocorrer que o não preenchimento da quota seja induzido pela organização que a administra, conforme seus objetivos particulares.

\footnotetext{
${ }^{35}$ Para informações mais específicas sobre a evolução do regime de $T R Q$ 's no Gatt/OMC consultar Hudec (1997)
} 
O principal risco nestas circunstâncias não é o de subpreenchimento das quotas tarifárias, mas sim o de arbitrariedade $^{36}$ na distribuição do comércio. Isso porque em especial nos monopólios estatais de comércio fatores de natureza política exercem papel dominante quanto a quem alocar as parcelas finais da quota.

Nota-se, então, um nítido caráter não orientado para o mercado nesse regime de alocação de quotas tarifárias. Segundo IATRC (2001), há queixas de que no caso dos monopólios estatais de comércio escolher-se-á limitar a quota a importações de baixo valor agregado, realizando-se a renda da quota e impedindo-se a concorrência direta do produto importado com o nacional.

Por fim, é de se observar que os métodos de administração de quotas tarifárias apresentados na sua forma pura não esgotam todas as possibilidades, visto que podem ser encontrados métodos híbridos, sujeitos ao imaginário e ao escrutínio do respectivo burocrata.

\subsubsection{Características específicas do regime de quotas tarifárias}

Embora a natureza do regime de quotas seja o principal elemento a ser observado por um potencial exportador acessando aquele mercado, o país importador pode estabelecer condições adicionais a serem implicitamente atendidas para o usufruto dos respectivos volumes de quota.

Entre as principais restrições adicionais destacam-se: a exigência da compra de certo valor de produto doméstico, o que eleva o custo unitário de acesso; a imposição de limites sobre parcelas de quotas, causando problemas de coordenação e economias de escala para exportadores mais distantes; e a exigência de certificados de exportação, que, por não possuírem mercado formal de troca, podem representar um importante custo fixo.

\footnotetext{
${ }^{36}$ Nesse caso, segundo o raciocínio de IATRC (2001), o método de administração das quotas deixa de ter por objetivo primário o mais eficiente uso dos recursos domésticos, o que asseguraria a importação pelas firmas de menor custo.
} 
Outro ponto inescapável em relação às quotas tarifárias é o da grande variação entre os volumes das mesmas, bem como entre os países beneficiados por tais volumes de acordo com o regime de locação utilizado. É também fato que dentro de uma mesma quota tarifária o produto de referência pode não ser homogêneo, sendo caso comum a ocorrência de muitos produtos contemplados na mesma quota tarifária. Sob tal prisma, em muitos casos nas notificações feitas à $\mathrm{OMC}$, um só valor reporta-se a todas as importações de diferentes produtos numa mesma quota tarifária.

Dentro de uma quota tarifária, a presença de várias alíneas de tarifas correspondendo a diferentes produtos dificulta, e muito, o estudo da real tarifa espelhada naquela quota tarifária. Isso porque quanto maior o detalhamento dos produtos reunidos sob uma mesma quota tarifária e quanto mais numerosas as tarifas específicas presentes mais dúvidas metodológicas ${ }^{37}$ terão de ser resolvidas para o cálculo da tarifa EAV final da quota.

Em especial para os EUA, Japão, Canadá e União Européia, a estrutura de tarifas NMF apresentada à OMC corresponde às tarifas intra e extraquota vigentes sobre seus parceiros comerciais, salvo disposição específica em acordo preferencial de comércio ou notificação específica à OMC.

Para tais grandes players do comércio agrícola mundial, o sistema de quotas torna-se uma ferramenta duplamente funcional na restrição de acesso a seus mercados. Primeiro, porque as tarifas NMF prevalecem relativamente altas. Segundo, porque se constituem regimes de quotas tarifárias não transparentes, conforme a simultaneidade de acordos preferenciais de comércio em vigência.

\footnotetext{
${ }^{37}$ Questões como: 1. Usar (qual?) ou não um esquema de ponderação?; 2. Com quais preços de conversão trabalhar? 3. Como ponderar a importância dos diferentes produtos dentro da quota tarifária?
} 
Ante todo o exposto quanto ao regime de quotas tarifárias, sua economia política, seus sistemas de alocação e suas dificuldades de clara mensuração, pode-se dizer que elas se constituem numa espécie de armadura sob os fluxos de comércio de produtos agrícolas e/ou agrícolas processados.

\subsubsection{As quotas tarifárias dos produtos agrícolas na União Européia}

De um prisma geral, a liberalidade permitida na montagem e notificação do exercício das quotas tarifárias por um país propiciou a vários membros da $\mathrm{OMC}$ - dentre os quais a UE - notificar importações com base em licenças concedidas aos importadores na quota ao invés de tomar por base as importações de fato. Isso gera uma medida de acesso superestimada quando os respectivos importadores não exercem todas as licenças de que foram beneficiários.

No caso da UE, o "spaghetti bowl" é ainda mais intenso, pois vários códigos comerciais (em nível de 10 dígitos do sistema harmonizado) aparecem em distintas quotas tarifárias.

Além disso, os compromissos de acesso assumidos na Rodada do Uruguai do Gatt resultaram na criação de 87 quotas tarifárias na UE. Elas foram criadas como provisão de acesso mínimo ${ }^{38}$, com o compromisso de permitir aos exportadores o acesso a ao menos $5 \%$ do consumo doméstico, independentemente do processo de tarificação, ou como provisão de acesso corrente, se destinadas a manter o acesso de importações históricas.

O número de 87 quotas tarifárias apresentadas pela UE à OMC não pode ser avaliado isoladamente pois os elementos relevantes na caracterização de um sistema de quotas tarifárias são os critérios de alocação da mesma, bem como os volumes por elas

\footnotetext{
${ }^{38}$ Para o conjunto dos países membro da OMC tais quotas estão definidas no nível de 4 dígitos do sistema harmonizado, devendo, em tese, ser alocadas com base no princípio de nação mais favorecida, conforme WTO (2002a)
} 
contemplados. Como características centrais do sistema de quotas tarifárias comunitárias, merecem apontamento os seguintes pontos levantados em IATRC (2001):

- 44 quotas tarifárias agregam um total de 155 linhas de tarifas em nível de oito dígitos do sistema harmonizado. Elas foram apresentadas na consolidação tarifária sob os compromissos de acesso corrente;

- 37 quotas tarifárias representam 160 alíneas de tarifas nesse mesmo nível de desagregação, notificadas em termos dos compromissos de acesso mínimo;

- as seis quotas tarifárias restantes reportam-se a sete linhas tarifárias no nível de oito dígitos do sistema harmonizado em legumes, sendo listadas separadamente;

- dessas 87 quotas tarifárias, algumas foram criadas como compensação a terceiros países por conta do acesso de Áustria, Finlândia e Suécia à UE: arroz (70.000 t.), aveia (10.000 t.), e carnes de aves (700 t.);

- há quotas tarifárias exclusivamente criadas no contexto de acordos bilaterais de disputas comerciais pregressas: carne bovina (20.000 t.), carnes de aves (15.500 t.), milho (500.000 t.) e trigo (300.00 t.), todas notificadas sob as regulações de acesso mínimo;

- acordos anteriores aos firmados na Rodada do Uruguai resultaram em negociações e abertura de quotas alocadas a países específicos: sorgo $(300.000$ t.) e milho (2.000.000 t.) exclusivamente para os Estados Unidos, e cortes bovinos de alta qualidade (37.800 t.) de uso particular de Estados Unidos, Canadá, Argentina, Austrália e Nova Zelândia;

- a UE criou quotas tarifárias de acesso mínimo exclusivamente onde e na medida em que as importações passadas, cobertas ou não por quotas de acesso corrente, estavam 
abaixo do percentual de consumo doméstico exigido pelos compromissos firmados no Acordo Agrícola.

UKFG (2002a) sustenta que na União Européia vigora um sistema sui generis de quotas tarifárias, no qual encontram-se tarifas intraquota bastante baixas combinadas com tarifas extraquota proibitivas, de forma que a quota tarifária assim definida funcionaria como uma quota pura. Esse argumento é ratificado pelas estimativas de Abbott (2001), reportando-se tarifa extraquota consolidada média de $45 \%$ contra uma tarifa intraquota consolidada média de $8 \%$, com base em dados de 2001 da OCDE.

No que se refere ao caráter impeditivo da tarifa extraquota para as quotas de acesso corrente, Bureau (2002) argumenta que há uma grande variância da razão entre tarifa extraquota e tarifa intraquota, conforme o produto. Em especial para as quotas que refletem parcerias comerciais históricas pré-OMC e pré-sistema de quotas, os níveis de proteção tendem a ser baixos, mesmo na tarifa extraquota.

De um ponto de vista geral, Bureau \& Tangermman (2000) advogam que as quotas tarifárias da União Européia têm sido cada vez mais preenchidas desde que foram criadas. Além disso, esses dois autores afirmam que a Comunidade tem sido cada vez mais honesta quando do momento de notificar as respectivas quotas tarifárias à $\mathrm{OMC}$ ao fazê-lo separadamente entre as quotas de acesso mínimo e de acesso corrente.

Sob esse ponto, países como EUA e Canadá não distinguem suas quotas tarifárias entre as de acesso mínimo e as de acesso corrente. Assim, torna-se difícil detectar se tarifas intraquota preferenciais têm sido concedidas a países específicos. Já a UE tem sido bem mais clara na hora de notificar suas quotas tarifárias, podendo-se identificar aquelas de acesso mínimo e as de acesso corrente, a saber: 
- a maior parte das quotas tarifárias de acesso corrente deriva de antigos acordos comerciais e têm volumes alocados em bases preferenciais. Nesse caso, são muitos os locatários exclusivos dessas quotas, destacando-se a República Popular da China, os países do centro e leste europeus e os países ACP;

- as quotas de acesso mínimo são administradas com base no conceito NMF, não sendo alocadas a um país específico, excetuadas as quotas tarifárias montadas para o arroz, caso em que há condições administrativas que discriminam no momento de locação da quota. Aqui, é preciso qualificar que há suspeitas de que em cinco quotas de carne de porco, três de carnes de aves, sete de lácteos e três de ovos processados a UE pode estar contabilizando importações preferenciais do leste Europeu nas respectivas quotas, em detrimento dos parceiros enquadrados no conceito $\mathrm{NMF}^{39}$.

Ao mesmo tempo, é necessário assinalar a presença de restrições administrativas $^{40}$ no processo de preenchimento de quotas tarifárias definidas pela Comunidade. Bureau (2002) e IATRC (2001) apontam que:

- os importadores de animais vivos, carne bovina, milho, arroz ou trigo devem ser registrados no sistema de impostos por valor agregado de ao menos um Estado membro da UE para serem elegíveis;

- há produtos que não podem ser importados quando para processamento. O suco de uva, por exemplo, não pode ser importado quando para a produção de vinho;

\footnotetext{
${ }^{39}$ Conforme referido em IATRC (2001) e Bureau (2001), o USDA tem alegado que a UE cobra tarifas mais baixas dos parceiros de Leste, mas contabiliza os volumes nas quotas tarifárias de acesso mínimo no conceito NMF. Porém, não há conclusão terminativa sobre a validade dessa afirmação.

${ }^{40}$ Inclusive, pode-se levantar a hipótese de que, quando as taxas de preenchimento das quotas são menores que $100 \%$ com importações totais maiores que o volume da quota, os importadores podem estar preferindo um procedimento administrativo mais simples (vendendo na tarifa extraquota) em lugar de uma tarifa mais baixa, que exigiria o atendimento de maiores burocracias.
} 
- em certos produtos, como o açúcar, é exigido um certificado de origem junto ao país exportador;

- itens como ovos, somente podem ser importados mediante lotes de quantidades mínimas. No caso dos ovos em específico, o importador tem que preencher um mínimo de 50 t. a cada dois anos;

- a validade das licenças de importação para alguns produtos é limitante para exportadores remotos. É o exemplo da licença de importação de trigo (dois dias) ou açúcar (trinta dias).

Especificamente quanto a suas imperfeições, o regime de quotas tarifárias da UE é assim definido nos trabalhos de IATRC (2001), Brasil (2001), Skully (2001) e Bureau (2002):

- em termos de volumes envolvidos, as quotas de acesso corrente tendem a ser muito maiores que aquelas criadas sob os auspícios do acesso mínimo;

- nos produtos em que a política de preços garantidos vêm sendo abandonada, tem sido menor a capacidade de preenchimento das respectivas quotas tarifárias pelos ofertantes externos. Em verdade, a proteção conferida pelo regime de quotas tarifárias no caso comunitário não é imune às modificações dos principais mecanismos de intervenção da Política Agrícola Comum;

- nos mercados domésticos da UE em que há um pequeno excesso de demanda, mesmo uma tarifa intraquota baixa em termos absolutos pode mostrar-se proibitiva. 
Além disso, para a UE não é possível distinguir entre as importações intra e extraquota unicamente pelos dados reportados em fluxos de comércio. Dependendo do nível de detalhamento da estrutura das quotas tarifárias notificadas e das estatísticas de comércio seria possível distinguir as importações realizadas no volume da quota tarifária daquelas realizadas fora desse volume. Mas isso não é possível no contexto da UE.

Por fim, o elemento mais criticado nas notificações de quotas tarifárias da União Européia refere-se ao fato de que o bloco notifica os volumes especificados nas licenças concedidas aos importadores, não se tratando objetivamente dos valores de fato importados. A UE se defende ao alegar que os importadores agraciados com volumes da quota tarifária são obrigados a fazer um depósito prévio em troca das licenças, o que inibiria o não exercício da mesma.

Em termos práticos, isso dificulta a mensuração dos compromissos de acesso mínimo de 5\% do consumo médio doméstico entre 1986 e 1988, vigorando a partir de 2000. À medida que não há estatísticas de consumo no nível de detalhamento dos fluxos de comércio, na hora de preenchimento das quotas privilegia-se o acesso dos produtos menos sensíveis, ou seja, operacionalmente, os menores volumes da quota agregada são alocados aos produtos mais sensíveis do ponto de vista da Comunidade. Esse problema é identificado principalmente nos mecanismos de quotas tarifárias para carnes e trigo.

Em específico do prisma dos interesses do Brasil, segundo Brasil (2001), entre as principais quotas tarifárias da UE encontram-se as de carnes bovina, suína, de frango e de peru, ovos, leite, laticínios, trigo, aveia, bananas e açúcar. 


\section{METODOLOGIA}

Para os efeitos desse trabalho, serão tomados os produtos definidos no Acordo Agrícola da Rodada do Uruguai à medida que representam a pauta objetivamente negociada como agrícola quando das negociações. Não obstante, muitos desses produtos apresentam já algum grau de processamento.

A descrição dos produtos sob análise consta da tabela abaixo e refere-se aos capítulos do sistema harmonizado ( $\mathrm{SH}$ ) de classificação de mercadorias.

Tabela 16. Produtos definidos no Acordo Agrícola.

\begin{tabular}{lc}
\hline Capítulo SH & Itens \\
\hline 1 e 2 & Todos \\
4 a 24 & Todos (exceto 1603 a 1605) \\
29 & 2905.43 a 2905.45 \\
33 & 33.01 \\
35 & 35.01 a 35.05 \\
38 & 3809.10 e 3823.60 \\
41 & 41.01 a 41.03 \\
43 & 43.01 \\
50 & 50.01 a 50.03 \\
51 & 51.01 a 51.03 \\
52 & 52.01 e 52.03 \\
53 & 53.01 e 53.02 \\
\hline
\end{tabular}

Fonte: Foreign Trade And Information Service (FTIS) (2002)

A cada subitem da metodologia é reservado um tratamento particular. 


\subsection{Tarifas ad valorem, específicas e EAV's}

Krugman \& Obstfeld (1994) caracterizam as tarifas ad valorem como taxas que são impostas como fração do valor do bem exportado, num aumento de custos para a aquisição pelo mercado importador. Para esses autores, as tarifas específicas são aquelas impostas na forma de um valor monetário cobrado para certa quantidade do bem importado.

Quanto maior o número de gravações tarifárias específicas ou mistas (componentes ad valorem e específico simultaneamente), menos transparente a proteção dada pelo regime tarifário. Isso se dá porque uma tarifa específica de, por exemplo, 100 euros/t. representará uma parcela flutuante do preço ao qual o respectivo produto chega a um dos portos importadores conforme as variações desse preço, ao passo que uma tarifa ad valorem significa proporção constante do preço de chegada ao mercado importador.

No caso dos produtos agrícolas Brasileiros exportados à União Européia, vale a conclusão de que:

"O uso de tarifa específica fornece, geralmente, maior proteção nominal que a proporcionada pela tarifa ad valorem, visto que a proteção tarifária cresce à medida que o preço do produto se reduz. Com isto, os produtores estrangeiros mais competitivos são relativamente mais prejudicados pela imposição da tarifa específica" (Brasil, 1999).

Já a idéia da tarifa EAV corresponde à transformação de tarifas específicas e/ou mistas em tarifas ad valorem ao se converter o componente específico em uma taxa, utilizando-se um preço de referência adequado. Esse preço dependerá do objeto de 
estudo e da disponibilidade da informação em cada caso: pode ser $C I F, F O B$, em US\$ segundo as exportações mundiais, em moeda do mercado importador, etc.

Algebricamente, pode-se resumir o processo de conversão de uma tarifa mista (ou específica) em ad valorem conforme a tabela abaixo:

Tabela 17. Tarifas compostas e EAV.

\begin{tabular}{lccc}
\hline Tarifa composta & Parte ad valorem $(\%)$ & Parte específica transformada & EAV (\%) \\
\hline $\mathrm{X} \%+\mathrm{Y} \$ / \mathrm{t}$. & $\mathrm{X}$ & $(\mathrm{Y} \$ / \mathrm{t}) /.(\mathrm{P} \$ / \mathrm{t})=.\mathrm{Z} \%$ & $(\mathrm{X}+\mathrm{Z})$ \\
\hline
\end{tabular}

Fonte: elaborado pelo autor com base em Krugman \& Obstfeld (1994)

Durante a Rodada do Uruguai da OMC, os produtos agrícolas dos países negociantes sujeitos a mecanismos de intervenção não tarifários viram-se submetidos ao processo de tarificação, através do qual toda a gama de medidas de proteção seria substituída por uma nova tarifa que fosse projetada a dar o mesmo nível de proteção que se estimava para o conjunto de mecanismos operantes naquela linha tarifária.

Sob tal cenário, e levando-se em conta que além da proteção tarifária muitos setores agrícolas contam com programas de suporte à produção e exportação, a imposição de uma tarifa tende a inverter a vantagem comparativa agrícola européia de importador para exportador de bens agrícolas, reforçando-se os movimentos de aumento do preço agrícola no interior do bloco e de queda no mercado mundial. Logo, vale duplamente o raciocínio segundo o qual futuros cortes nas tarifas consolidadas provavelmente terão um impacto significativo sobre fluxos de comércio.

\subsubsection{Tarifas equivalentes ad valorem}

É preciso alguma cautela no que tange à medição de uma pauta tarifária repleta de tarifas específicas e de alíneas tarifárias que são objeto de quotas tarifárias. É o que ocorre com a pauta de tarifas da União Européia que se analisa neste trabalho. 
Em primeiro lugar, é necessário olhar com cuidado o nível de agregação para o qual as tarifas são reduzidas, de modo a se calcular suas estatísticas básicas.

Um segundo ponto relaciona-se à dificuldade em se trabalhar com quotas tarifárias formadas por mais de uma linha tarifária (produto). Para o caso japonês, por exemplo, IATRC (2001) cita duas quotas tarifárias: a primeira consistindo de duas linhas tarifárias e a segunda consistindo de seis linhas tarifárias, sempre para leite em pó desnatado nas suas variações. Dentro dessa segunda quota tarifária, a tarifa intraquota varia de $0 \%$ a $35 \%$, enquanto a extraquota vai de $0 \%$ a $33 \%$, mais um componente específico de 438 yen/kg ou 470 yen/kg, conforme a linha tarifária. Assim, uma mesma quota tarifária pode representar diferentes impactos sobre distintos produtos.

Em terceiro lugar, o uso de esquemas de ponderação exige que os resultados finais sejam criticados à luz dos inconvenientes que cada esquema resulta. $\mathrm{O}$ mesmo IATRC (2001) mostra, ainda referindo-se à pauta tarifária NMF do Japão, que em uma das duas quotas tarifárias para leite em pó desnatado, a média simples das seis alíneas tarifárias ali contempladas é de $20 \%$ no conceito intraquota e de $19 \%$ mais 454 yen/ $\mathrm{Kg}$ na tarifa extraquota. Essa mesma quota tarifária ponderada pelos respectivos volumes de comércio do Japão gerou resultados totalmente distintos: $1 \%$ na tarifa intraquota e $1 \%$ mais 438 yen/Kg no conceito extraquota.

Logo, há sensibilidade do resultado final à estrutura de ponderação adotada, sendo razoável argumentar que os esquemas de ponderação geram resultados cujas ressalvas são dificilmente identificáveis no caso de um grande número de tarifas mensuradas. Em certo sentido, as médias finais ponderadas para os diferentes produtos do comércio agrícola variarão conforme as especificidades dos respectivos mercados importador, exportador e mundial (suas estruturas de oferta e demanda).

Todavia, é de se anotar que há autores que defendem o uso da tarifa ponderada. Bach e Martin (2002), citados em Bureau (2002) argumentam que a média ponderada pelo comércio é uma aproximação de primeira ordem da verdadeira tarifa. $\mathrm{O}$ próprio Bureau, em seu trabalho com Salvatici (2001), conclui que a média não 
ponderada não mostra qualquer relação com a verdadeira tarifa teórica, pois a tarifa média não ponderada perde sentido ao ponderar da mesma forma commodities importantes e mercadorias irrelevantes na produção e no comércio.

No caso da União Européia, a base de tarifas fornecia diferentes quotas tarifárias estruturadas numa mesma alínea tarifária em oito dígitos de desagregação. Com vistas a captar o mais alto nível de proteção da estrutura tarifária optou-se por tomar como representativa a quota tarifária com maior tarifa EAV nas alíneas caracterizadas pela presença do mecanismo de quotas tarifárias.

Por fim, resta a questão de qual preço de referência usar para a conversão das tarifas específicas em tarifa EAV. Em termos das bases de dados disponíveis para esse estudo, tratar-se-ão todas as alíneas em oito dígitos do sistema harmonizado, utilizando-se três diferentes preços de referência para a conversão das tarifas específicas. A discussão da adequação de cada um dos preços disponíveis pretende ser uma das contribuições produzidas nesse estudo.

Enquanto estratégia de trabalho, para os objetivos aqui definidos procedeuse da seguinte forma.

Como primeiro passo, tomou-se como base tarifária representativa a base de dados Taric, divulgada em 31 de outubro de 2003 no site da União Européia. Essa base de tarifas é disponibilizada em formato pdf e apresenta três anexos que permitem um trabalho mais detalhado quanto à estrutura de proteção tarifária da UE. Esses anexos são um anexo de quotas tarifárias, um anexo de tarifas sazonais e sistema de preços de entrada e um anexo que enquadra a tarifa adicional vigente nos casos em que o produto sob análise apresenta percentagem de outro componente agrícola, teor de açúcar, leite ou farinha ${ }^{41}$.

\footnotetext{
${ }^{41}$ Além dessas complexidades, há uma série de minúcias quanto à apresentação e interpretação dos dados da Taric. Para esses casos, construiu-se um anexo com o detalhamento dos procedimentos técnicos adotados. Ver Anexo A.
} 
Essa base de tarifas está definida para o conceito de NMF, começou a vigorar a partir de $1^{\circ}$ de janeiro de 2004 e tem a mesma definição das tarifas presentes na oferta agrícola da UE ao Mercosul em 2001. Sob esse ponto, segundo a Divisão de Produtos de Base do Ministério das Relações Exteriores, o Brasil é tratado sob a cláusula de Nação Mais Favorecida (NMF) na maioria dos produtos agrícolas exportados para a União Européia. $^{42}$

Num segundo estágio, as tarifas específicas e mistas tiveram seus componentes específicos transformados em ad valorem pelo método ilustrado à tabela precedente. Com tal intuito, foram usados três preços de referência: valores médios das exportações mundiais em US\$ no período 1999 a 2001, valores europeus de importação em euros em 2000 e valores médios de exportação do Brasil para o mundo em US\$ de janeiro a outubro de 2003.

Além disso, nas situações em que não havia uma compatibilização estrita entre a alínea tarifária e o vetor de preços no nível de oito dígitos, optou-se pelo preço com até o $6^{\circ}$ dígito comum, respeitando-se também a similaridade de descrição do produto.

Especificamente em relação aos cálculos da tarifa média ponderada pelos fluxos comerciais, os valores calculados o foram no nível de seis dígitos do sistema harmonizado, dada a não compatibilidade entre as definições de fluxos de comércio e bases de tarifas para detalhamentos além do sexto dígito. Nesse caso, empregaram-se as tarifas em oito dígitos consolidadas pela máxima tarifa até o sexto dígito comum e os fluxos comerciais consolidados pelo seu total até o sexto dígito comum.

Após uma discussão dos resultados em termos da adequação de cada um dos preços de referência, será escolhido um deles para as avaliações específicas em termos de tarifas sazonais e sistema de preços de entrada, estatísticas de mensuração por

\footnotetext{
${ }^{42}$ Segundo Castilho (2000): “... a tarifa NMF é a tarifa base da União Européia, sobre a qual se aplicam as margens preferenciais, quando existem, e a partir da qual são negociadas as reduções tarifárias”.
} 
capítulo agrícola, picos tarifários, mecanismos de gatilhos e quotas tarifárias, bem como para o cálculo dos indicadores sugeridos.

\subsubsection{Tarifas sazonais e sistema de preços de entrada}

No caso da União Européia, as tarifas sazonais e o sistema de preços de entrada estão concentrados nos capítulos 07 e 08 do sistema harmonizado. Há uma clara associação linear inversa entre os preços de entrada e a respectiva tarifa específica incidente em cada sazonalidade dentro de uma mesma alínea tarifária.

De fato, as tarifas específicas são projetadas para serem, em tese, propositalmente maiores sob a ocorrência de menores preços de entrada. Nestes termos, medir-se-á para cada alínea identificada por tal mecanismo o número de sazonalidades que ela comporta, a correlação entre preço de entrada e tarifa específica em cada sazonalidade e a correlação média naquela alínea.

\subsection{Estatísticas de mensuração}

No contexto dos estudos avaliando níveis de tarifas praticados no comércio mundial são, de regra, utilizadas estatísticas básicas como instrumentos de análise. Nesse quadro, as sempre referidas são a média aritmética (com ou sem componente de ponderação), a mediana e o desvio padrão. Essas estatísticas são aceitas e utilizadas como medida inicial do grau de proteção na literatura que se ocupa do tema.

Bussab \& Morettin (1987) caracterizam assim tais estatísticas:

a) média aritmética: a soma das observações dividida pelo número delas;

b) mediana: o valor que ocupa a posição central da série de observações quando elas estão ordenadas segundo suas grandezas (crescente ou decrescentemente); 
c) desvio padrão: a raiz quadrada positiva da variância, que por sua vez é expressa como o desvio quadrático médio de uma série de dados.

Cumpre também esclarecer que, dada a referida complexidade da estrutura tarifária da UE para os produtos sob análise, essas estatísticas tornam-se mais interessantes quando analisadas em conjunto. Sob tal aspecto, Gibson et al. (2001) afirmam que embora a relação entre média e mediana represente um contínuo, quatro combinações de tais estatísticas estão associadas a interpretações econômicas. A citar:

- média alta/mediana alta: elevada proteção na maioria das linhas tarifárias;

- média alta/mediana baixa: elevado nível de proteção para alguns produtos específicos, embora a maioria das tarifas seja relativamente baixa;

- média baixa/mediana baixa: reduzida proteção na maioria das linhas tarifárias;

- média baixa/mediana alta: reduzido nível de proteção para alguns produtos específicos, ainda que a maioria das linhas tarifárias seja relativamente alta.

Em relação à média, a literatura de regra contextualiza a validade de calculála sob ponderação. Ademais, o cálculo da média simples surge como um procedimento de cautela, posto que:

“... em última análise não há um esquema de ponderação isento de 'senões' e a transparência do cálculo não ponderado tem vantagens". (Gibson et al., 2001) 
Como principais problemas quanto ao uso dos esquemas de ponderação comumente utilizados tem-se:

- ponderação baseada nos valores de importação: como refere Bureau (2002), a tarifa média ponderada é viesada porque ela dá pouco peso às tarifas altas, por conta da correlação inversa entre nível de tarifa e volume de importação;

- a ponderação baseada em parcelas do valor doméstico da produção tende a viesar a média para cima porque outros fatores além de tarifa (suporte doméstico, por exemplo) podem afetar o nível de produção de um item agrícola;

- ponderar-se pela participação da produção doméstica no consumo interno também é alternativa teoricamente citada; porém, os dados de produção e consumo domésticos nos níveis de desagregação desejados não estão em geral disponíveis.

Tendo-se em vista a inexistência de um método perfeito de cálculo da tarifa média, neste estudo serão calculadas a média simples e a média ponderada pelos fluxos de comércio. No caso da média ponderada pelos fluxos de comércio, os pesos de ponderação serão dados pelos próprios fluxos comerciais dos quais foram extraídos os preços de conversão das tarifas específicas e mistas ${ }^{43}$.

Ainda em termos de estatísticas básicas, o conceito de tarifa máxima arremete à tarifa EAV de maior magnitude num grupo de observação, enquanto a idéia de tarifa mínima reporta à tarifa EAV de menor magnitude numa pauta de tarifas.

Uma leitura adicional que se pode fazer a partir das estatísticas básicas calculadas é análoga àquela apresentada em Buarque (2003). Nesse trabalho, constrói-se

\footnotetext{
${ }^{43}$ Exportações mundiais em US\$ no período 1999 a 2001, importações européias em euros no ano de 2000, e exportações Brasileiras para o mundo em US\$ no período de janeiro a outubro de 2003.
} 
uma hierarquização de variáveis ao se quantificar o grau de influência ou de dependência que as mesmas exercem entre si no contexto de um dado problema.

Com isso, cada variável pode ser avaliada por meio de um eixo de coordenadas conforme os graus de dependência e de influência a ela atribuídos. Isso permite mapeá-las em relação ao objeto de estudo, conforme o diagrama a seguir.

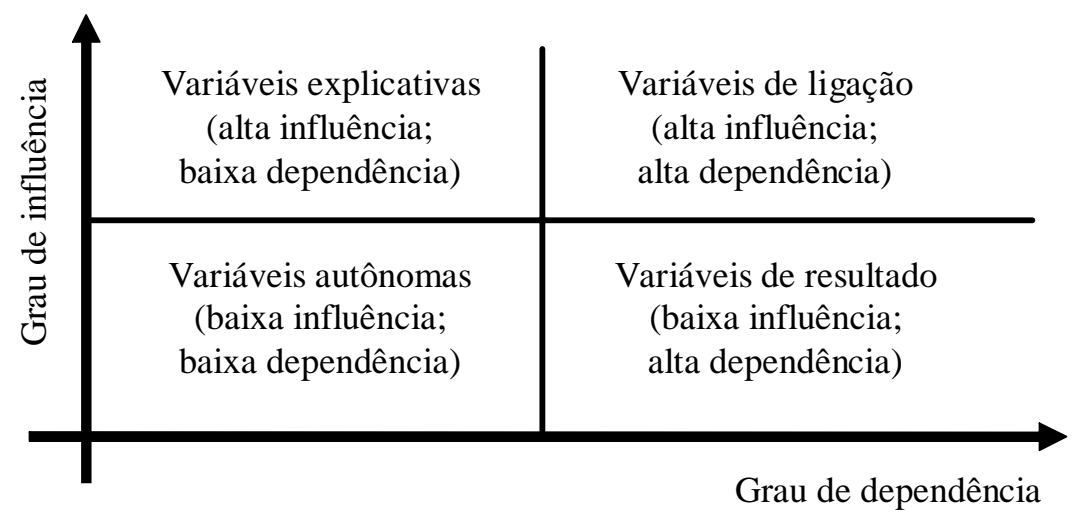

Figura 9 - Grau de dependência x grau de influência de variáveis.

Fonte: elaborado pelo autor com base em Buarque (2003)

Esse raciocínio será aproveitado na análise conjunta da média e do desvio padrão dos grupos de produtos vis a vis a média e o desvio padrão da pauta como um todo (representáveis pelo ponto $\mathrm{P}$ na figura abaixo, por exemplo). Isso possibilitará a seguinte leitura hierarquizada dos produtos sob análise. 


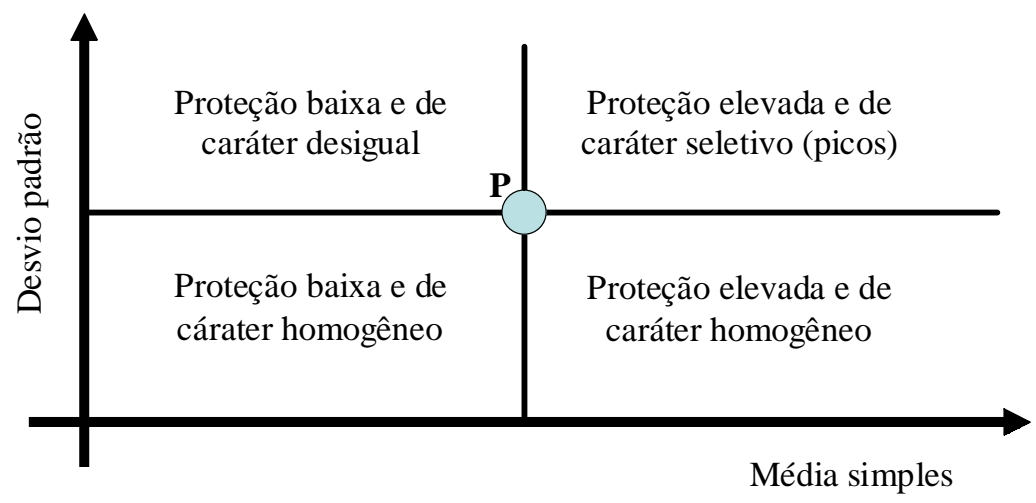

Figura 10 - Hierarquia de proteção tarifária frente à pauta.

Enfim, cumpre referir outro indicador recorrente em termos de estatísticas pontuais usadas quanto à interpretação de um painel de dados: a estatística de qui quadrado. De acordo com Bussab \& Morettin (1987), uma das maneiras de quantificar descritivamente o grau de dependência entre duas variáveis é através da medida $X^{2}$ (qui quadrado), definida por:

$$
X^{2}=\sum_{i}\left(\left(o_{i}-e_{i}\right)^{2} / e_{i}\right)
$$

Sendo que na equação precedente, $o_{i}$ é a freqüência observada e $e_{i}$, a freqüência esperada, sob a hipótese de independência. Quanto maior o valor de $X^{2}$, mais o observado se afasta do esperado, e maior a dependência.

No espírito desse trabalho, esse indicador seria calculado para avaliar a hipótese Ho: $\mathrm{p}_{i j}=\mathrm{p}_{i}{ }^{*} \mathrm{p}_{\cdot j}$, isto é, o nível tarifário $\left(\mathrm{p}_{i}\right)$ não está associado à divisão por capítulo agrícola $\left(\mathrm{p}_{j}\right)$ contra Ha: $\mathrm{p}_{i j} \neq \mathrm{p}_{i \cdot}{ }^{*} \mathrm{p}_{\cdot j}$, na qual o nível tarifário está associado à divisão por capítulo agrícola. De fato, os valores esperados (sob a hipótese de independência) aplicáveis à fórmula acima seriam dados pelo produto das probabilidades marginais. Dentro de um grupo de tarifas pode-se tomar um conjunto de valores esperados da seguinte forma: 


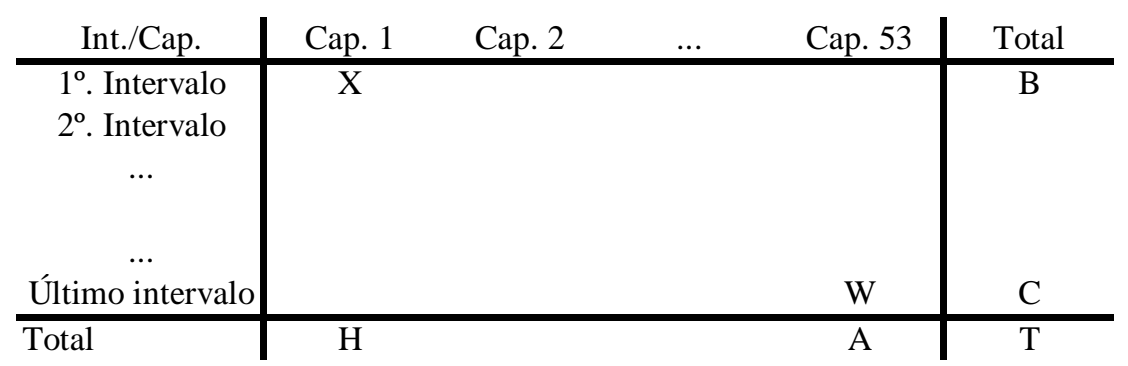

Figura 11 - Valores esperados para o cálculo do coeficiente de contingência.

Fonte: elaborado pelo autor com base em Bussab \& Morettin (1987)

Teoricamente, sob a hipótese de não associação entre capítulo agrícola e nível tarifário (intervalos tarifários associáveis à noção de pico tarifário, por exemplo), o valor de $\mathrm{X}$ seria igual a $\left(\mathrm{B}^{*} \mathrm{H}\right) / \mathrm{T}$ e o valor de $\mathrm{W}$ seria igual a $\left(\mathrm{C}^{*} \mathrm{~A}\right) / \mathrm{T}$ e sucessivamente para todos os pontos tabulados. Daí sairiam os valores $e_{i}$ da fórmula acima. Os valores observados dependem apenas da definição do tamanho dos intervalos tarifários.

Implicitamente, o que essa avaliação permite aferir é se a distribuição de tarifas entre os capítulos agrícolas afasta-se daquela verificada para o total da pauta tarifária. Em outras palavras, se a distribuição de tarifas para os diversos grupos de produtos não é comum.

Além disso, a cada estatística de qui quadrado é possível calcular o respectivo coeficiente de contingência de Pearson, com valor teórico entre zero e um. Valores próximos a um sugerem dependência entre as variáveis observadas. Isto feito, tal estatística permite, por exemplo, avaliar se há dependência linear entre capítulo agrícola e intervalo tarifário, ou seja, se os capítulos são discriminados entre si.

À parte do trabalho em termos de estatísticas básicas, calcular-se-á também o coeficiente de contingência de Pearson. Com vistas à operacionalização desse coeficiente, sugere-se utilizar como definição de pico o patamar de $15 \%$ na tarifa extraquota. 


\subsection{Pico Tarifário}

Posto que a literatura específica não apresenta consenso quanto à definição estrita do patamar de proteção que identifica uma tarifa como pico tarifário, utilizar-seão dois critérios de pico tarifário, ambos na tarifa EAV extraquota. O primeiro, considerando pico tarifário as tarifas EAV extraquota acima de $25 \%$ e o segundo definindo pico tarifário as alíneas superiores à mediana de toda a pauta tarifária. A mediana tem uma vantagem sobre a média, ou seja, ela não é influenciada pela dispersão das tarifas. Os dois critérios merecem ter seus resultados comparados para fins de análise do padrão de incidência de picos entre os capítulos agrícolas.

Com esses dois critérios, propõe-se identificar a participação dos picos tarifários em cada capítulo agrícola, de modo que os grupos de produtos se tornem comparáveis entre si sob esse aspecto. Além disso, tendo-se em vista que os picos tarifários podem a associar-se à presença de tarifas específicas ou mistas, será também medida a participação dessas tarifas por capítulo agrícola.

\subsection{Mecanismo de gatilhos}

Nesse subitem proceder-se-á ao levantamento da proporção de alíneas sujeitas ao mecanismo de salvaguardas especiais em cada capítulo agrícola.

Essa informação não consta da base de tarifas original de modo que será o resultado do cruzamento dessa base tarifária consolidada em oito dígitos de desagregação com a última estrutura tarifária notificada pela União Européia à OMC em $2002^{44}$.

\footnotetext{
44 Vide o site da OMC: http://www.wto.org/english/tratop_e/schedules_e/goods_schedules_e.htm
} $(1 / 01 / 2004)$ 


\subsection{Quotas tarifárias}

Como já referido, a base Taric divulgada pela UE em 31 de outubro último contempla um anexo de quotas tarifárias, permitindo identificá-las no nível de oito dígitos de desagregação. Tomando-se a quota sob maior incidência tarifária em cada alínea, serão calculadas, por capítulo agrícola, estatísticas básicas nos conceitos intraquota e extraquota, obedecendo-se à metodologia já explicitada no tópico das tarifas com vistas à conversão de todas as tarifas em EAV.

Com tais procedimentos, será possível mapear o número de alíneas e participação desse mecanismo em cada capítulo agrícola. Como instrumento adicional de leitura da presença e impacto das quotas tarifárias entre as linhas tarifárias avaliadas, calculou-se também o Indicador de Tarifa Extraquota (ITEQ), sugerido como contribuição do presente trabalho em subitem especifico a frente.

Para tal, aproveitaram-se as tarifas EAV calculadas na consolidação da base de tarifas. Uma vez tomadas essas tarifas nas suas definições intra e extraquota, aplicouse a fórmula do respectivo indicador, classificando-se decrescentemente as alíneas com presença de quota tarifária conforme o ITEQ obtido.

Com os resultados de valor médio do indicador por capítulo, cada capítulo foi avaliado no universo de linhas tarifárias sob $T R Q$ (casos em que a tarifa extraquota foi, de fato, maior que a tarifa intraquota), identificando-se os capítulos "sob proteção" e aqueles que seriam "líderes de proteção".

\subsection{Duas propostas originais de contribuição}

Com base no trabalho de revisão teórica dos índices recomendados para a avaliação de uma pauta tarifária como a da UE, observou-se uma grande dificuldade em se dispor de ferramentas que melhorem a leitura dos níveis de dispersão de tarifas ou que permitam identificar o efeito da presença do mecanismo de quotas tarifárias. 
Isso posto, sugerem-se dois indicadores concebidos como ferramentas adicionais no sentido de melhor compreender o papel da dispersão de tarifas, bem como de hierarquizar o quantum de proteção a presença de uma $T R Q$ representa.

Os indicadores sugeridos são, respectivamente, o Indicador de Concentração por Capítulo (ICC) ${ }^{45}$ e o Indicador de Tarifa Extraquota (ITEQ).

\subsubsection{Indicador de Concentração por Capítulo (ICC)}

O intuito do presente indicador é apontar os capítulos no nível de oito dígitos do sistema harmonizado que têm sido alvo de picos tarifários concentrados ao se defrontar com o mercado comunitário. Algebricamente, o resultado do indicador por capítulo $j$ poderia ser assim definido:

$$
\mathrm{ICC}_{j}=\left(\mathrm{DP}_{j} / \mathrm{DP}\right)
$$

em que:

$j$ - qualquer capítulo com registro de alínea tarifária superior a certa definição de pico tarifário;

DP $j$ - desvio padrão calculado somente com as tarifas superiores ao nível de pico tarifário adotado, nos capítulos do comércio agrícola em que tal ocorrer;

DP - desvio padrão calculado para toda a pauta do comércio agrícola em mãos.

O indicador per si consiste da razão entre o desvio-padrão por capítulo para os itens selecionados e o desvio padrão de toda a pauta. Valores inferiores a " 1 " significam que o capítulo foi protegido pela estrutura tarifária sob análise. Tal indicador

\footnotetext{
${ }^{45}$ Conversível para outros critérios de agrupamento de produtos que não os de capítulos do sistema harmonizado necessariamente.
} 
foi imaginado em conjunto com o pesquisador André Meloni Nassar e é tanto mais interessante quanto mais desagregados os dados originais.

Para esse indicador, o resultado é gerado tomando-se por base uma definição de pico tarifário escolhida. Com base nos argumentos apresentados à revisão teórica, propõe-se como conceito de pico tarifário relevante o de tarifas superiores a $25 \%$ na tarifa extraquota. $\mathrm{O}$ cálculo do indicador em si consiste de:

- selecionar os itens de tarifas sofridas pelo Brasil, quando com tarifa acima da respectiva definição de pico tarifário;

- classificar os itens selecionados por capítulo do sistema harmonizado;

- calcular o desvio padrão por capítulo a partir dos itens classificados;

- avaliar o desvio padrão calculado por capítulo vis a vis o desvio padrão calculado para todos os itens registrados em oito dígitos.

\subsubsection{Indicador de tarifa extraquota (ITEQ)}

Um dos claros problemas presentes ao se analisar pautas tarifárias que apresentam linhas tarifárias com alíneas definidas, simultaneamente, dentro de um volume de quota e fora do volume de quota, é a dificuldade em se identificar o grau de proteção que esse mecanismo imprime aos produtos das respectivas alíneas de tarifa.

Isto em mente e dispondo-se de uma série de linhas tarifárias apresenta-se como contribuição adicional desse estudo um segundo indicador, o qual procura medir o nível de proteção que a quota tarifária confere a certo produto numa pauta tarifária consolidada.

A idéia básica é a de medir, para cada linha com presença de quota tarifária, o quantum a tarifa extraquota sobrepõe de proteção vis a vis sua respectiva tarifa 
intraquota. Para tal, é necessário que todas as tarifas (dentro ou fora da quota) estejam já convertidas em equivalentes ad valorem, preferencialmente para níveis de desagregação não inferiores a seis dígitos do sistema harmonizado, ou seus correspondentes para outros critérios de classificação. Algebricamente, o comentário precedente poderia ser assim apresentado:

$$
\mathrm{ITEQ}_{i}=\left(T R Q_{i} \text { extra/TRQ } Q_{i} \text { intra }\right)
$$

em que:

$i$ - $\quad$ alínea tarifária em seis ou mais dígitos do sistema harmonizado;

$T R Q$ - extra: tarifa equivalente ad valorem mais alta incidente na respectiva alínea além da quota tarifária;

$T R Q$ - intra: tarifa equivalente ad valorem incidente na respectiva alínea dentro da quota tarifária.

Uma vez separadas as alíneas tarifárias com a presença de quota tarifária e calculados um a um os respectivos indicadores ITEQ, seria possível ordená-las decrescentemente e classificá-las conforme o seguinte critério, aproveitando-se por um lado a ocorrência da quota tarifária e, por outro, sua dimensão no universo de bens sujeitos à ocorrência de quota tarifária:

- ITEQ $_{i}>1$ e ITEQ $_{i}<$ ITEQ médio dos itens sob quota tarifária: produtos sob proteção;

- ITEQ $_{i}>1$ e ITEQ ${ }_{i}>$ ITEQ médio dos itens sob quota tarifária: produtos que lideram a proteção. 
Uma vez ordenadas tais linhas tarifárias é possível identificar, por exemplo, os capítulos do sistema harmonizado mais afetados pelo mecanismo de quotas tarifárias.

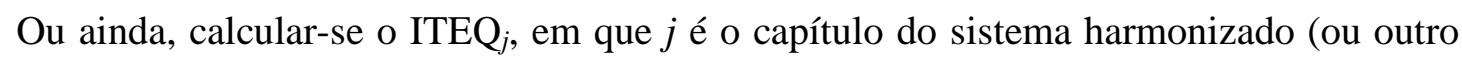
critério relevante para o agrupamento de bens) congregando $n$ bens. Com isso, seria possível obterem-se ITEQ's médios ${ }^{46}$ por capítulo, classificando-se os capítulos em "sob proteção" ou de "liderança em proteção".

Observem-se duas características adicionais que tal indicador apresenta. Primeiro, ele exclui da análise as linhas tarifárias em que as tarifas intraquota e extraquota são iguais, e, para tal, exige a identificação dessas alíneas. Como segundo ponto, ele obriga a localização das alíneas em que a tarifa intraquota é de $0 \%$ contra uma tarifa extraquota positiva, posto que o indicador não se define nesses casos. Por conta disso, sugere-se que tal indicador seja complementado pela identificação dos casos em que a tarifa salta de $0 \%$ no regime intraquota para uma tarifa extraquota positiva.

\subsection{Estimativas de suporte}

Para avaliação das estimativas de suporte à produção agropecuária na UE, foram usados os dados do coeficiente nominal de suporte. Esse indicador é produzido e divulgado desde 1986 pela OCDE e, de acordo com Rijswick \& Silvis (2000), mede a razão entre as receitas brutas da atividade agropecuária sob a vigência das políticas de intervenção e essas mesmas receitas num cenário de preços mundiais e sem apoio doméstico.

Nesses termos, quando o indicador resulta 2,5, por exemplo, a receita bruta auferida pela respectiva atividade agropecuária - com as políticas de intervenção vigentes - é igual a 2,5 vezes a receita que seria obtida se o produtor sob análise fosse exclusivamente remunerado aos preços mundiais, sem suporte orçamentário.

Algebricamente, esse coeficiente pode ser assim representado:

\footnotetext{
${ }^{46}$ Ponderados ou não.
} 
$\mathrm{Na}$ equação precedente, ESP é a estimativa de suporte ao produtor e contempla as seguintes políticas de suporte: suporte de preços garantidos, pagamentos baseados em produção, pagamentos por cabeça ou hectare, pagamentos baseados em níveis históricos de produção, pagamentos baseados no uso de insumos, pagamentos baseados em uso limitado de insumos, pagamentos baseados na renda total da propriedade e pagamentos diversos (que, no caso da UE, correspondem aos pagamentos oriundos dos orçamentos dos países membros e não da Comunidade). Já o termo $(\mathrm{Q} * \mathrm{~Pb})$ é igual ao respectivo valor da produção remunerada aos preços de mercado mundial.

Por sua construção, quando o indicador resulta " 1 " significa que a produção doméstica é remunerada nos níveis de fronteira ou de preços do mercado mundial.

Esse dado apresenta-se para 20 categorias de produtos em valores anuais que estiveram disponíveis de 1986 a 2002. Essa extensão de dados foi avaliada em dois procedimentos, a citar:

i) o crescimento ou decrescimento do coeficiente médio entre os triênios que limitam o período de dados disponíveis, isto é, entre 1986/88 e 2000/02;

ii) foram construídas regressões lineares simples em função do tempo, avaliando-se a existência de alguma tendência de aumento ou redução de apoio aos produtores comunitários ao longo do período analisado.

Nesse segundo ponto, avaliaram-se os coeficientes de explicação das equações estimadas e, sobretudo, a significância estatística dos coeficientes estimados para a variável tempo. Segundo Bussab (1988), o coeficiente de explicação de uma regressão linear simples representa a porcentagem de variação total na variável 
dependente explicada pelo modelo $\mathrm{y}_{\mathrm{i}}=\mathrm{E}\left(\mathrm{Y} / \mathrm{x}_{\mathrm{i}}\right)+\mathrm{e}_{\mathrm{i}}=\alpha+\beta^{*} \mathrm{x}_{\mathrm{i}}+\mathrm{e}_{\mathrm{i}}$. Para os propósitos desse trabalho, $\mathrm{y}_{\mathrm{i}}$ corresponde ao CNS (uma proxy do suporte doméstico na UE) e $\mathrm{x}_{\mathrm{i}}$ corresponde à variável tempo (em anos).

Assim, procurou-se aferir o comportamento do suporte à agropecuária na União Européia sob as reformas parciais da PAC em 1992 e 2000. É de se anotar que esses 20 setores categorizados pelo indicador da $\mathrm{OCDE}^{47}$ são calculados em nível mais agregado do que as estatísticas tarifárias e de comércio, mas ainda permitem associação com os produtos agrupados em capítulos do sistema harmonizado.

\subsection{Oferta agrícola da UE ao Mercosul}

A oferta agrícola comunitária feita em 2001 no fórum biregional MercosulUnião Européia apresentou cinco categorias de produtos conforme o período sugerido de desgravação tarifária. Essas categorias foram agrupadas em anexos, assim definidos:

- anexo A: zeragem imediata das tarifas ad valorem;

- anexo B: zeragem gradual e linear em quatro anos das tarifas ad valorem;

- anexo C: zeragem gradual e linear em sete anos das tarifas ad valorem;

- anexo D: zeragem gradual e linear em 10 anos das tarifas ad valorem;

- anexo E: não definido cronograma de desgravação.

\footnotetext{
${ }^{47}$ Os setores contemplados pelo indicador da OCDE são os seguintes: trigo, trigo comum, trigo duro, grãos para ração, outros grãos, milho, cevada, aveia, colza, soja, oleaginosas, arroz, sementes de girassol, equivalente açúcar refinado, lácteos, carne bovina, carne ovina, carne de aves, carne suína e ovos.
} 
Essa oferta de desgravação tarifária incluiu 771 produtos no nível de oito dígitos de desagregação do SH versão 1996. Além disso, é de se notar que as reduções foram propostas apenas nos componentes ad valorem.

O caráter conservador dessa proposta inicial foi apontado pelo Mercosul no processo de negociação biregional de forma que, em 2003, os dois blocos formalizaram a apresentação de novas ofertas cruzadas. Todavia, no caso da UE, a revisão da oferta original de 2001 implicou melhoria residual no contexto dos produtos do Acordo Agrícola.

A nova proposta da Comunidade foi definida em oito dígitos do SH de 2002 e acenou com a mesma estrutura de anexos estabelecida inicialmente. Segundo Brasil (2003), a nova oferta da UE representou melhoria em cerca de 100 produtos ante a um universo inicial de 9.286 códigos tarifários. Além disso, essa proposta de março de 2003 continuou a ignorar qualquer desgravação tarifária para os itens do anexo E.

Com uma proposta (re)definida nesses termos, torna-se possível identificar os grupos de produtos relativamente protegidos, ou seja, aqueles dominantemente presentes nos anexos D e E. Logo, a oferta agrícola então produzida pela União Européia terá seus produtos identificados por capítulos agrícolas e esses avaliados conforme sua presença nos anexos D e E.

\subsection{Política agrícola versus proteção tarifária}

Dentre os subitens dessa metodologia, os dois últimos não se referem a instrumentos de proteção tarifária. Porém, com base nos objetivos desse texto, os setores discriminados pela estrutura tarifária da União Européia serão cruzados com aqueles avaliados pelas estimativas de suporte e com aqueles elencados na oferta agrícola proposta pelo bloco europeu ao Mercosul em 2001 e revisada em 2003. 


\subsection{Bases de dados}

Em termos de acesso a mercados, a implementação dos compromissos firmados na Rodada do Uruguai levou à diferenciação entre as tarifas aplicada e consolidada. As tarifas aplicadas (no limite equiparáveis às tarifas consolidadas) são aquelas vigentes no momento de sua mensuração, enquanto as tarifas consolidadas são as notificadas à OMC dentro dos compromissos de redução dos níveis tarifários praticados entre os países. Segundo as definições de WTO (2002b), Brasil (2001) e Bureau (2002), para a União Européia as tarifas aplicadas e consolidadas são iguais em termos das bases de dados aproveitadas para este trabalho.

As tarifas aqui empregadas foram exclusivamente as da Taric, divulgada em 31 de outubro de 2003. Encontram-se definidas na versão de 2002 do SH.

Os valores de exportações Brasileiras para o mundo também se encontraram definidos nessa versão do SH (NCM Brasileira de 31/07/2002) e foram extraídos do sistema Alice. Já os preços mundiais de exportação reportaram-se ao período de 1999 a 2001, foram extraídos da base de dados Comtrade das Nações Unidas e adequados por similaridade de nomenclatura e descrição à versão 2002 do SH, nos casos em que tal foi necessário. $\mathrm{O}$ mesmo procedimento foi empregado em relação aos valores europeus de importação de 2000 extraídos da Amad, caso em que o vetor de valores referia-se ao SH de 1996.

Para as situações em que foi exigida a conversão de dólares norteamericanos em euros, utilizaram-se valores médios a partir das cotações mensais extraídas junto ao Banco Central Europeu.

As estimativas de suporte foram coletadas em OECD (2003). Já os números da oferta agrícola da UE ao Mercosul foram obtidos em Brasil (2003). 


\section{RESULTADOS}

No primeiro subitem dos resultados serão apresentados os valores resultantes de três distintos preços de referência usados no processo de conversão das tarifas em EAV. Em paralelo, será feita uma discussão acerca das virtudes e limitações de cada um dos preços de referência, optando-se por um deles para o desenvolvimento das demais avaliações propostas na metodologia.

Os subitens seguintes (exceto o último) referem-se aos seguintes elementos: tarifas sazonais e sistema de preços de entrada, teste de qui quadrado, indicador de concentração por capítulo, picos tarifários, quotas tarifárias, estimativas de suporte e oferta agrícola da União Européia.

Já o último subitem exibe os números relativos à proporção de $T R Q$ 's, de tarifas específicas (ou mistas) e de salvaguardas especiais por capítulo agrícola. Esse ponto também constitui um fechamento dos resultados, apresentando-se os capítulos agrícolas mais gravados pelas políticas de apoio, tarifas sazonais e oferta agrícola da UE ao Mercosul.

Para todos os efeitos, nos capítulos $16,29,33,35,38,41,43$, e 50 a 53 as alíneas objeto de análise foram somente as caracterizadas pelo Acordo Agrícola da Rodada do Uruguai, conforme explicitado na metodologia. 


\subsection{Tarifas EAV por estatísticas básicas}

Os preços das exportações mundiais apresentam um evidente gap quanto à disponibilidade dos dados. Por ser uma consolidação de informações dos países, os dados fechados mais recentes reportavam-se ao ano de 2001. Essa condicionante obriga a um descasamento de períodos entre a base de tarifas e a base de fluxos comerciais.

Uma segunda desvantagem desse vetor de preços é que eles são afetados por variáveis do lado da oferta (tecnologia e políticas de suporte de cada nação) que pouco têm a ver com a oferta agrícola comunitária. Ao mesmo tempo, os preços mundiais são afetados por preferências que não são necessariamente européias.

Além disso, por se tratar de valores em dólares, o uso desses preços passa necessariamente pela taxa de câmbio euro/dólar norte-americano, já que as tarifas específicas e mistas estão definidas em euros no caso da UE. Pode-se considerar esse ponto uma desvantagem dessa base de preços à medida em que modernamente a taxa de câmbio é uma variável decisivamente afetada por fluxos de divisas que são antes financeiras que comerciais. Em contrapartida, é um vetor de preços menos parcial da ótica negociadora, pois depende menos da dinâmica importadora ou exportadora de uma única nação.

Já os preços de importação da UE se encontram reportados em euros, eliminando-se a passagem pela variável taxa de câmbio. Outro ponto a favor dessa base de preços é o fato de que ela corresponderia a um valor característico do mercado importador, incorporando efeitos para mais dos preços de intervenção e políticas de suporte, bem como o poder de compra relativamente mais alto do mercado consumidor da UE. Aliás, por conta desse elemento, seria de se esperar uma tarifa EAV relativamente mais baixa em função de preços relativamente mais altos.

Outro ponto a advogar a favor dessa base de preços é que para muitos produtos agrícolas a importação comunitária não é função somente da oferta Brasileira, 
donde o mercado local é abastecido pelos produtores locais e por produtores de diversos países do mundo que não somente o Brasil.

Contudo, dados de importações da União Européia no nível de desagregação desse texto estão disponíveis somente nas bases de dados pagas da Eurostat. Trata-se de bases de dados de custo proibitivo. Por conta disso utilizaram-se os dados de 2000 publicamente disponibilizados pela Amad, o que infelizmente não contorna a questão do descasamento entre os períodos da base de tarifas e da base de fluxos comerciais.

Por fim, os preços de exportação do Brasil para o mundo também passam pelo condicionante da conversão de dólares norte-americanos para euros.

Todavia, constituem material prontamente disponível no período de interesse através do sistema Alice. Em tese, esses preços captam a capacidade exportadora Brasileira nos produtos avaliados, notando-se que o valor relevante para o Brasil é o pelo qual ele exporta e não o valor pelo qual a UE importa, pois o Brasil não possui seguradora e transporte de bandeira própria de forma que seguros e fretes não são receita para o exportador Brasileiro.

De modo geral, dada a reconhecida capacidade exportadora Brasileira em um grande número das linhas tarifárias avaliadas, é mesmo razoável que o preço de exportação Brasileiro seja menor que o preço das exportações mundiais. Esses, por sua vez, seriam inferiores aos preços europeus de importação, até porque a UE é o maior consumidor de agrícolas e de agrícolas processados no mundo. Por decorrência, teoricamente a tarifa EAV gerada pelo preço de exportação Brasileiro seria maior que a tarifa EAV produzida pelos preços mundiais e essa última maior que a tarifa EAV resultante a partir dos preços europeus de importação.

Empiricamente, as estatísticas tarifárias calculadas com cada um dos preços de referência são apresentadas nas três tabelas subseqüentes. 
Tabela 18. Estatísticas tarifárias utilizando-se os preços das exportações mundiais (1999-2001).

\begin{tabular}{|c|c|c|c|c|c|c|c|}
\hline Capítulo agrícola (SH) & $\begin{array}{c}\text { Média } \\
\text { Simples } \\
(\%)\end{array}$ & $\begin{array}{c}\text { Média } \\
\text { Ponderada } \\
(\%)\end{array}$ & $\begin{array}{l}\text { Mediana } \\
(\%)\end{array}$ & $\begin{array}{l}\text { DP } \\
(\%)\end{array}$ & $\begin{array}{c}\text { Mínimo } \\
(\%)\end{array}$ & $\begin{array}{c}\text { Máximo } \\
(\%)\end{array}$ & Alíneas \\
\hline Animais vivos $(01)$ & 22 & 50 & 9 & 24 & 0 & 66 & 55 \\
\hline Carnes e miudezas (02) & 38 & 79 & 23 & 42 & 0 & 255 & 232 \\
\hline Leite e laticínios (04) & 112 & 115 & 63 & 125 & 0 & 529 & 175 \\
\hline Outros itens de origem animal (05) & 0 & 0 & 0 & 1 & 0 & 5 & 21 \\
\hline Planta vivas e floricultura (06) & 6 & 9 & 7 & 4 & 0 & 12 & 42 \\
\hline Produtos hortícolas (07) & 17 & 30 & 12 & 27 & 0 & 237 & 107 \\
\hline Frutas (08) & 14 & 66 & 9 & 23 & 0 & 211 & 128 \\
\hline Café e mates (09) & 3 & 2 & 0 & 4 & 0 & 13 & 42 \\
\hline Cereais (10) & 73 & 80 & 85 & 45 & 0 & 122 & 55 \\
\hline Malte, amidos e féculas (11) & 67 & 70 & 51 & 52 & 8 & 271 & 83 \\
\hline Sementes e oleaginosos (12) & 7 & 2 & 0 & 37 & 0 & 318 & 77 \\
\hline Gomas e resinas vegetais (13) & 2 & 3 & 0 & 5 & 0 & 19 & 18 \\
\hline Matérias para entrançar (14) & 0 & 0 & 0 & 0 & 0 & 0 & 8 \\
\hline Óleos animais ou vegetais (15) & 14 & 21 & 6 & 35 & 0 & 285 & 125 \\
\hline Preparações de carne e peixes (16) & 26 & 60 & 17 & 25 & 9 & 131 & 45 \\
\hline Açúcares e confeitaria (17) & 60 & 154 & 46 & 57 & 0 & 199 & 47 \\
\hline Cacau e preparações (18) & 34 & 38 & 38 & 21 & 0 & 104 & 27 \\
\hline Preparações de cereais (19) & 39 & 64 & 36 & 30 & 9 & 139 & 51 \\
\hline Preparações de hortícolas (20) & 27 & 82 & 18 & 32 & 0 & 248 & 311 \\
\hline Preparações alimentícias (21) & 19 & 43 & 12 & 22 & 0 & 95 & 42 \\
\hline Bebidas e vinagres (22) & 14 & 20 & 5 & 32 & 0 & 258 & 177 \\
\hline Resíduos de ind. Alimentares (23) & 58 & 65 & 10 & 93 & 0 & 442 & 66 \\
\hline Tabaco e manufaturados (24) & 35 & 50 & 29 & 20 & 10 & 109 & 30 \\
\hline Produtos químicos orgânicos (29) & 72 & 110 & 70 & 29 & 39 & 115 & 5 \\
\hline Óleos essenciais e resinóides (33) & 3 & 4 & 3 & 2 & 0 & 7 & 31 \\
\hline Matérias albuminóides e colas (35) & 12 & 16 & 8 & 12 & 0 & 39 & 25 \\
\hline Produtos diversos de ind. quím. (38) & 29 & 36 & 29 & 6 & 22 & 36 & 4 \\
\hline Peles e couros $(41)$ & 0 & 0 & 0 & 0 & 0 & 0 & 19 \\
\hline Peleteria e suas obras (43) & 0 & 0 & 0 & 0 & 0 & 0 & 9 \\
\hline Seda $(50)$ & 0 & n.d. ${ }^{1}$ & 0 & 0 & 0 & 0 & 4 \\
\hline Lã e pêlos finos ou grosseiros (51) & 0 & 0 & 0 & 0 & 0 & 0 & 17 \\
\hline Algodão (52) & 0 & 0 & 0 & 0 & 0 & 0 & 6 \\
\hline Outras fibras têxteis vegetais (53) & 0 & 0 & 0 & 0 & 0 & 0 & 7 \\
\hline Todos os itens & 33 & 46 & 15 & 58 & 0 & 529 & 2.091 \\
\hline
\end{tabular}

${ }^{1}$ Não foi encontrado comércio, mas as tarifas são de $0 \%$. 
Tabela 19. Estatísticas tarifárias utilizando-se os preços das importações da UE (2000)

\begin{tabular}{|c|c|c|c|c|c|c|c|}
\hline Capítulo agrícola (SH) & $\begin{array}{c}\text { Média } \\
(\%)\end{array}$ & $\begin{array}{c}\text { Média } \\
\text { Ponderada } \\
(\%)\end{array}$ & $\begin{array}{c}\text { Mediana } \\
(\%)\end{array}$ & $\begin{array}{l}\text { DP } \\
(\%)\end{array}$ & $\begin{array}{c}\text { Mínimo } \\
(\%)\end{array}$ & $\begin{array}{c}\text { Máximo } \\
(\%)\end{array}$ & Alíneas \\
\hline Animais vivos (01) & 21 & 86 & 5 & 30 & 0 & 108 & 55 \\
\hline Carnes e miudezas (02) & 31 & 75 & 21 & 34 & 0 & 192 & 232 \\
\hline Leite e laticínios (04) & 117 & 105 & 42 & 243 & 0 & 818 & 175 \\
\hline Outros itens de origem animal (05) & 0 & 0 & 0 & 1 & 0 & 5 & 21 \\
\hline Planta vivas e floricultura (06) & 6 & 5 & 7 & 4 & 0 & 12 & 42 \\
\hline Produtos hortícolas (07) & 13 & 28 & 12 & 19 & 0 & 149 & 107 \\
\hline Frutas (08) & 12 & 41 & 9 & 14 & 0 & 118 & 128 \\
\hline Café e mates (09) & 3 & 0 & 0 & 4 & 0 & 13 & 42 \\
\hline Cereais (10) & 43 & 65 & 44 & 31 & 0 & 118 & 55 \\
\hline Malte, amidos e féculas (11) & 24 & 31 & 19 & 18 & 3 & 86 & 83 \\
\hline Sementes e oleaginosos (12) & 2 & 1 & 0 & 6 & 0 & 52 & 77 \\
\hline Gomas e resinas vegetais (13) & 2 & 2 & 0 & 5 & 0 & 19 & 18 \\
\hline Matérias para entrançar (14) & 0 & 0 & 0 & 0 & 0 & 0 & 8 \\
\hline Óleos animais ou vegetais (15) & 15 & 15 & 6 & 38 & 0 & 308 & 125 \\
\hline Preparações de carne e peixes (16) & 21 & 51 & 17 & 17 & 9 & 97 & 45 \\
\hline Açúcares e confeitaria (17) & 30 & 54 & 18 & 28 & 0 & 114 & 47 \\
\hline Cacau e preparações (18) & 37 & 10 & 35 & 32 & 0 & 167 & 27 \\
\hline Preparações de cereais (19) & 35 & 54 & 31 & 27 & 9 & 144 & 51 \\
\hline Preparações de hortícolas (20) ${ }^{1}$ & n.d & n.d. & n.d & n.d & n.d & n.d & n.d \\
\hline Preparações alimentícias (21) & 14 & 24 & 12 & 11 & 0 & 40 & 42 \\
\hline Bebidas e vinagres (22) & 9 & 14 & 4 & 24 & 0 & 207 & 177 \\
\hline Resíduos de ind. Alimentares (23) & 30 & 90 & 4 & 101 & 0 & 678 & 66 \\
\hline Tabaco e manufaturados (24) & 31 & 31 & 24 & 19 & 10 & 83 & 30 \\
\hline Produtos químicos orgânicos (29) & 32 & 36 & 30 & 6 & 25 & 41 & 5 \\
\hline Óleos essenciais e resinóides (33) & 3 & 4 & 3 & 2 & 0 & 7 & 31 \\
\hline Matérias albuminóides e colas (35) & 9 & 8 & 8 & 7 & 0 & 24 & 25 \\
\hline Produtos diversos de ind. quím. (38) & 19 & 23 & 20 & 4 & 13 & 23 & 4 \\
\hline Peles e couros (41) & 0 & 0 & 0 & 0 & 0 & 0 & 19 \\
\hline Peleteria e suas obras (43) & 0 & 0 & 0 & 0 & 0 & 0 & 9 \\
\hline Seda (50) & 0 & 0 & 0 & 0 & 0 & 0 & 4 \\
\hline Lã e pêlos finos ou grosseiros (51) & 0 & 0 & 0 & 0 & 0 & 0 & 17 \\
\hline Algodão (52) & 0 & 0 & 0 & 0 & 0 & 0 & 6 \\
\hline Outras fibras têxteis vegetais (53) & 0 & 0 & 0 & 0 & 0 & 0 & 7 \\
\hline Todos os itens & 28 & 34 & 12 & 82 & 0 & 818 & 2.091 \\
\hline
\end{tabular}

Os valores de importação europeus não estiveram disponíveis em relação aos produtos do capítulo 20. (preparações de hortícolas) 
Tabela 20. Estatísticas tarifárias com os preços das exportações Brasileiras totais. (janeiro a outubro de 2003)

\begin{tabular}{|c|c|c|c|c|c|c|c|}
\hline Capítulo agrícola (SH) & $\begin{array}{c}\text { Média } \\
\text { Simples } \\
(\%)\end{array}$ & $\begin{array}{c}\text { Média } \\
\text { Ponderada } \\
(\%)\end{array}$ & $\begin{array}{c}\text { Mediana } \\
(\%)\end{array}$ & $\begin{array}{l}\text { DP } \\
(\%)\end{array}$ & $\begin{array}{c}\text { Mínimo } \\
(\%)\end{array}$ & $\begin{array}{l}\text { Máximo } \\
(\%)\end{array}$ & Alíneas \\
\hline Animais vivos (01) & 35 & 16 & 4 & 58 & 0 & 147 & 55 \\
\hline Carnes e miudezas (02) & 70 & 127 & 40 & 113 & 0 & 805 & 232 \\
\hline Leite e laticínios (04) & 91 & 101 & 76 & 64 & 0 & 284 & 175 \\
\hline Outros itens de origem animal (05) & 0 & 0 & 0 & 1 & 0 & 5 & 21 \\
\hline Planta vivas e floricultura (06) & 6 & 8 & 7 & 4 & 0 & 12 & 42 \\
\hline Produtos hortícolas (07) & 20 & 45 & 12 & 40 & 0 & 229 & 107 \\
\hline Frutas (08) & 18 & 51 & 9 & 52 & 0 & 572 & 128 \\
\hline Café e mates (09) & 3 & 0 & 0 & 4 & 0 & 13 & 42 \\
\hline Cereais (10) & 59 & 101 & 46 & 52 & 0 & 125 & 55 \\
\hline Malte, amidos e féculas (11) & 35 & 74 & 31 & 31 & 6 & 227 & 83 \\
\hline Sementes e oleaginosos (12) & 3 & 0 & 0 & 10 & 0 & 83 & 77 \\
\hline Gomas e resinas vegetais (13) & 2 & 11 & 0 & 5 & 0 & 19 & 18 \\
\hline Matérias para entrançar (14) & 0 & 0 & 0 & 0 & 0 & 0 & 8 \\
\hline Óleos animais ou vegetais (15) & 13 & 7 & 6 & 30 & 0 & 244 & 125 \\
\hline Preparações de carne e peixes (16) & 51 & 142 & 17 & 63 & 9 & 227 & 45 \\
\hline Açúcares e confeitaria (17) & 76 & 264 & 60 & 82 & 0 & 285 & 47 \\
\hline Cacau e preparações (18) & 52 & 22 & 46 & 47 & 0 & 198 & 27 \\
\hline Preparações de cereais (19) & 48 & 76 & 37 & 35 & 9 & 154 & 51 \\
\hline Preparações de hortícolas (20) & 24 & 57 & 18 & 21 & 0 & 212 & 311 \\
\hline Preparações alimentícias (21) & 24 & 36 & 12 & 49 & 0 & 312 & 42 \\
\hline Bebidas e vinagres (22) & 30 & 66 & 25 & 49 & 0 & 380 & 177 \\
\hline Resíduos de ind. Alimentares (23) & 114 & 50 & 10 & 409 & 0 & 195 & 66 \\
\hline Tabaco e manufaturados (24) & 39 & 39 & 34 & 26 & 10 & 156 & 30 \\
\hline Produtos químicos orgânicos (29) & 88 & 82 & 82 & 37 & 48 & 143 & 5 \\
\hline Óleos essenciais e resinóides (33) & 3 & 6 & 3 & 2 & 0 & 7 & 31 \\
\hline Matérias albuminóides e colas (35) & 11 & 11 & 8 & 13 & 0 & 45 & 25 \\
\hline Produtos diversos de ind. quím. (38) & 32 & 39 & 32 & 7 & 24 & 39 & 4 \\
\hline Peles e couros (41) & 0 & 0 & 0 & 0 & 0 & 0 & 19 \\
\hline Peleteria e suas obras (43) & 0 & 0 & 0 & 0 & 0 & 0 & 9 \\
\hline Seda $(50)$ & 0 & 0 & 0 & 0 & 0 & 0 & 4 \\
\hline Lã e pêlos finos ou grosseiros (51) & 0 & 0 & 0 & 0 & 0 & 0 & 17 \\
\hline Algodão (52) & 0 & 0 & 0 & 0 & 0 & 0 & 6 \\
\hline Outras fibras têxteis vegetais (53) & 0 & 0 & 0 & 0 & 0 & 0 & 7 \\
\hline Todos os itens & 38 & 53 & 15 & 95 & 0 & 805 & 2.091 \\
\hline
\end{tabular}


Observando-se a pauta agregada nos três resultados acima, é de se notar que as maiores diferenças entre média, desvio padrão e máximo ocorrem com o uso dos preços de importação europeus e dos preços exportação Brasileiros. Sob esse aspecto, o preço das exportações mundiais produz a distribuição mais bem comportada.

Já a média tarifária calculada para todos os itens avaliados foi maior com o uso dos preços de exportação Brasileiros; intermediária utilizando-se o preço das exportações mundiais e encontrou seu menor valor sob os preços de importação europeus. Também no caso do desvio padrão, o resultado mais alto deu-se com o uso dos preços de exportação Brasileiros.

Em todos os três casos, a média foi superior à mediana, o que sugere elevado nível de proteção para alguns produtos específicos, ainda que a maioria das tarifas seja relativamente baixa. Simultaneamente, os valores baixos e muito próximos das medianas calculadas sugerem que o preço de referência utilizado é questão particularmente delicada no contexto das tarifas acima da mediana.

Observando-se as tarifas geradas nos grupos de produtos em cada caso, compararam-se os produtos em que a média e a mediana estiveram acima dos respectivos valores para a pauta agregada.

Houve sete grupos de produtos em que a maior média foi gerada pelos preços de exportação Brasileiros: carnes e miudezas, açúcares e confeitaria, cacau e preparações, preparações de cereais, resíduos de indústrias alimentares, tabaco e manufaturados e produtos químicos orgânicos. Para leite e laticínios os preços de importação europeus geraram a maior média tarifária e, no caso dos cereais, a média mais alta ocorreu sob os preços das exportações mundiais.

Em relação à mediana, houve oito grupos de produtos em que o maior valor ocorreu com os preços de exportação Brasileiros: carnes e miudezas, leite e laticínios, açúcares e confeitaria, cacau e preparações, preparações de cereais, tabaco e manufaturados, produtos químicos orgânicos e produtos diversos das indústrias 
químicas. Em dois casos, a maior mediana tarifária se deu com os preços das exportações mundiais: cereais e malte, amidos e féculas.

Além disso, é de se pontuar que o desvio padrão de cada grupo de produtos foi claramente afetado pelo preço de referência empregado. Com os preços de exportação Brasileiros houve oito capítulos agrícolas nos quais o desvio padrão tarifário foi maior que 50\%; isso ocorreu quatro vezes com os preços das exportações mundiais e duas vezes sob os preços de importação europeus.

Essa discussão ratifica o que se projetaria teoricamente.

Isso posto, as avaliações subseqüentes serão feitas considerando-se as tarifas produzidas sob os preços de exportação Brasileiros. Em primeiro lugar, porque esses preços se reportam a um período relativamente vantajoso. Em paralelo, é de se reconhecer que a atividade exportadora Brasileira orienta-se antes por esses preços que pelos preços das exportações mundiais ou pelos preços de importação europeus.

Não obstante, com vistas à implementação do referido no último parágrafo, realizou-se um ajuste necessário. Identificaram-se os produtos que não compõem o rol de bens exportados pelo Brasil para o mundo. Isso resultou na eliminação de 25 itens que são importados pelo bloco, mas não exportados pelo Brasil. Um exemplo representativo é o do trigo búlgaro. Esses produtos constam em anexo. Esse ajuste gerou uma nova tabela de tarifas calculadas. 
Tabela 21. Ajuste das estatísticas tarifárias com os preços das exportações Brasileiras totais.

\begin{tabular}{|c|c|c|c|c|c|c|c|}
\hline Capítulo agrícola (SH) & $\begin{array}{c}\text { Média } \\
\text { Simples } \\
(\%)\end{array}$ & $\begin{array}{c}\text { Média } \\
\text { Ponderada } \\
(\%)\end{array}$ & $\begin{array}{c}\text { Mediana } \\
(\%)\end{array}$ & $\begin{array}{l}\mathrm{DP} \\
(\%)\end{array}$ & $\begin{array}{c}\text { Mínimo } \\
(\%)\end{array}$ & $\begin{array}{c}\text { Máximo } \\
(\%)\end{array}$ & Alíneas \\
\hline Animais vivos (01) & 35 & 16 & 4 & 58 & 0 & 147 & 54 \\
\hline Carnes e miudezas (02) & 70 & 127 & 40 & 113 & 0 & 805 & 231 \\
\hline Leite e laticínios (04) & 90 & 101 & 76 & 64 & 0 & 284 & 172 \\
\hline Outros itens de origem animal (05) & 0 & 0 & 0 & 1 & 0 & 5 & 21 \\
\hline Planta vivas e floricultura (06) & 6 & 8 & 7 & 4 & 0 & 12 & 42 \\
\hline Produtos hortícolas (07) & 20 & 45 & 12 & 40 & 0 & 229 & 107 \\
\hline Frutas $(08)$ & 17 & 51 & 9 & 53 & 0 & 572 & 123 \\
\hline Café e mates (09) & 3 & 0 & 0 & 4 & 0 & 13 & 42 \\
\hline Cereais (10) & 61 & 101 & 76 & 52 & 0 & 125 & 53 \\
\hline Malte, amidos e féculas (11) & 33 & 74 & 30 & 22 & 6 & 107 & 81 \\
\hline Sementes e oleaginosos (12) & 1 & 0 & 0 & 3 & 0 & 17 & 75 \\
\hline Gomas e resinas vegetais (13) & 2 & 11 & 0 & 5 & 0 & 19 & 18 \\
\hline Matérias para entrançar (14) & 0 & 0 & 0 & 0 & 0 & 0 & 8 \\
\hline Óleos animais ou vegetais (15) & 13 & 7 & 6 & 30 & 0 & 244 & 125 \\
\hline Preparações de carne e peixes (16) & 51 & 142 & 17 & 63 & 9 & 227 & 45 \\
\hline Açúcares e confeitaria (17) & 76 & 267 & 60 & 82 & 0 & 285 & 47 \\
\hline Cacau e preparações (18) & 52 & 22 & 46 & 47 & 0 & 198 & 27 \\
\hline Preparações de cereais (19) & 50 & 76 & 42 & 36 & 9 & 154 & 47 \\
\hline Preparações de hortícolas (20) & 24 & 57 & 18 & 21 & 0 & 212 & 309 \\
\hline Preparações alimentícias (21) & 24 & 36 & 12 & 49 & 0 & 312 & 42 \\
\hline Bebidas e vinagres (22) & 30 & 66 & 25 & 49 & 0 & 380 & 177 \\
\hline Resíduos de ind. Alimentares (23) & 80 & 50 & 5 & 301 & 0 & 195 & 63 \\
\hline Tabaco e manufaturados (24) & 39 & 39 & 34 & 26 & 10 & 156 & 30 \\
\hline Produtos químicos orgânicos (29) & 88 & 82 & 82 & 37 & 48 & 143 & 5 \\
\hline Óleos essenciais e resinóides (33) & 3 & 6 & 3 & 2 & 0 & 7 & 31 \\
\hline Matérias albuminóides e colas (35) & 11 & 11 & 8 & 13 & 0 & 45 & 25 \\
\hline Produtos diversos de ind. quím. (38) & 32 & 39 & 32 & 7 & 24 & 39 & 4 \\
\hline Peles e couros (41) & 0 & 0 & 0 & 0 & 0 & 0 & 19 \\
\hline Peleteria e suas obras (43) & 0 & 0 & 0 & 0 & 0 & 0 & 9 \\
\hline Seda $(50)$ & 0 & 0 & 0 & 0 & 0 & 0 & 4 \\
\hline Lã e pêlos finos ou grosseiros (51) & 0 & 0 & 0 & 0 & 0 & 0 & 17 \\
\hline Algodão (52) & 0 & 0 & 0 & 0 & 0 & 0 & 6 \\
\hline Outras fibras têxteis vegetais (53) & 0 & 0 & 0 & 0 & 0 & 0 & 7 \\
\hline Todos os itens & 37 & 53 & 15 & 80 & 0 & 805 & 2.066 \\
\hline
\end{tabular}


Com base nos números imediatamente anteriores, dois subgrupos de produtos são particularmente gravados pelas tarifas da UE.

Carnes e miudezas, açúcares e confeitaria e resíduos de indústrias alimentares apresentaram, a um só tempo, tarifa média simples acima da média da pauta, desvio padrão tarifário acima do desvio padrão tarifário da pauta e tarifa máxima acima de $100 \%$. Esse pode ser considerado um grupo de produtos prejudicados em termos de tarifas em acesso ao mercado consumidor da UE.

Além desses três grupos de produtos, notaram-se também capítulos agrícolas em que a média tarifária simples esteve acima da média simples da pauta, a mediana tarifária esteve acima da mediana da pauta e a tarifa máxima suplantou $100 \%$. Trata-se de um segundo subgrupo, também prejudicado em nível de acesso ao bloco europeu: leite e laticínios, cereais, preparações de carne e peixes, cacau e preparações, preparações de cereais, tabaco e manufaturados e produtos químicos orgânicos.

A própria comparação dos valores de média e desvio padrão dos produtos em relação ao total da pauta realça a proteção focada em dois conjuntos de bens. Em primeiro lugar, sobre carnes e miudezas, açúcares e confeitaria e resíduos de indústrias alimentares. E, num segundo momento, sobre tabaco e manufaturados, preparações de carne e peixes, cereais, cacau e preparações, preparações de cereais, leite e laticínios e produtos químicos orgânicos. Vide a figura a seguir. 


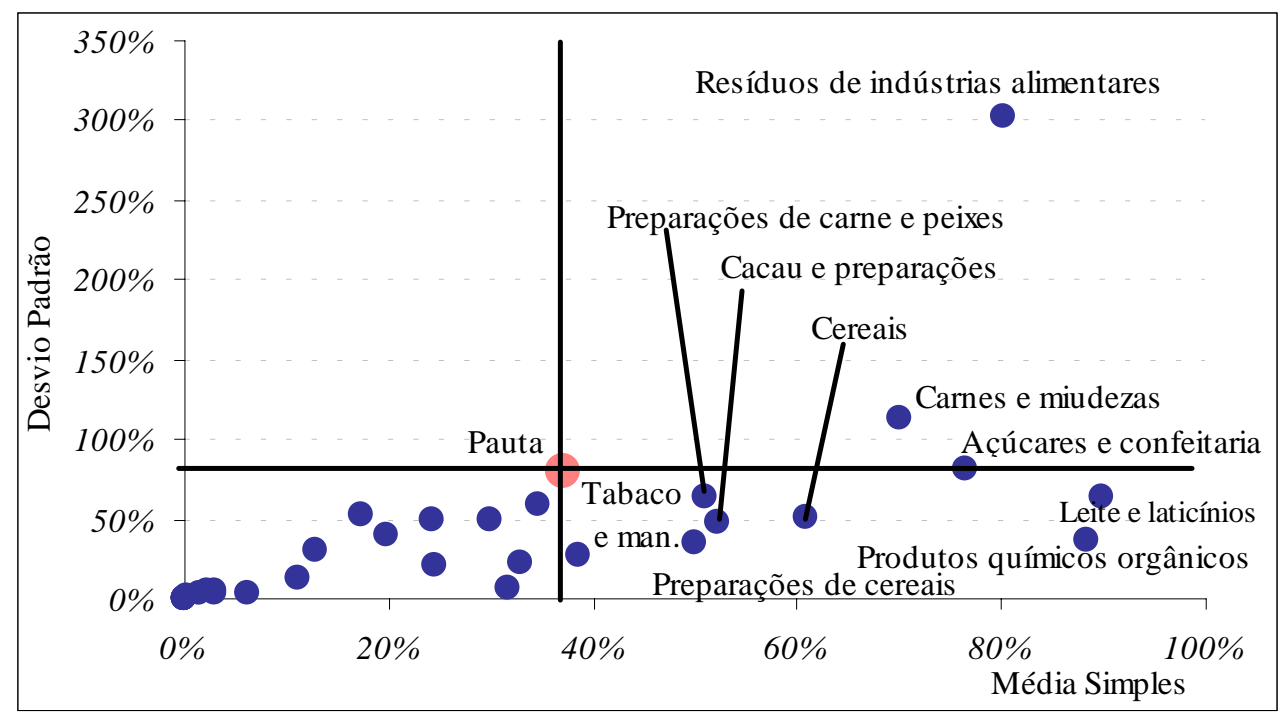

Figura 12 - Discriminação relativa de produtos agrícolas na pauta tarifária da UE.

Um outro ponto marcante pode ser extraído da comparação entre a média simples e a média ponderada. A teoria sugere que a média ponderada ficaria abaixo da média simples porque a ponderação pelos fluxos de comércio seria afetada pela proteção tarifária, isto é, as tarifas mais altas corresponderiam a um pequeno fluxo comercial e, portanto, receberiam pouco ou nenhum peso no processo de ponderação.

Empiricamente, as médias simples e ponderada não ratificaram esse argumento.

As simulações com as três bases de preços resultaram em uma tarifa média ponderada acima da média simples, no total da pauta tarifária. Esse crescimento da tarifa média empregando-se o esquema de ponderação foi mais marcante com os preços das exportações Brasileiras totais (16 pontos percentuais na versão ajustada).

Em verdade, o uso das exportações agrícolas Brasileiras para o mundo como ponderação das tarifas praticadas pela UE sobre o Brasil ressalta o caráter seletivo das tarifas comunitárias nos produtos agrícolas em que o Brasil é um forte exportador nos mercados mundiais. Com o uso da ponderação pelas exportações agrícolas Brasileiras 
totais, a tarifa média da UE viu-se magnificada para 16 grupos de produtos em relação à média simples; reduziu-se em sete grupos de itens e manteve-se em dois grupos de $\operatorname{produtos}^{48}$.

Esse crescimento da tarifa média dada tal estrutura de ponderação ocorreu com carnes e miudezas, leite e laticínios, plantas vivas e floricultura, produtos hortícolas, frutas, cereais, malte, amidos e féculas, gomas e resinas vegetais, preparações de carne e peixes, açúcares e confeitaria, preparações de cereais, preparações de hortícolas, preparações alimentícias, bebidas e vinagres, óleos essenciais e resinóides e produtos diversos das indústrias químicas.

\subsection{Tarifas sazonais e preços de entrada}

Foram identificados quatro capítulos agrícolas sujeitos a esse instrumento da política comercial da UE: quatro alíneas de produtos hortícolas, 20 alíneas em frutas, quatro alíneas de preparações de hortícolas, e quatro alíneas de bebidas e vinagres.

Particularmente em relação aos preços de entrada é interessante notar que:

- há sazonalidades em que a UE permite a incidência da chamada tarifa autônoma, de regra, menor que a tarifa convencional. Porém, como é a tarifa convencional que está associada ao preço de entrada, a mesma foi mantida para os fins de quantificação do respectivo coeficiente de correlação. $\mathrm{O}$ intuito é mostrar como o mecanismo pode funcionar na sua forma mais restritiva ao comércio;

- há casos em que vigora somente uma tarifa ad valorem constante na sazonalidade. Isso fez com que, em alguns produtos, o número de sazonalidades diferisse do número de coeficientes de correlação calculados;

- no caso de preparações de hortícolas e de bebidas e vinagres não vigoram sazonalidades, apenas tarifação específica variando em função do preço de entrada

\footnotetext{
${ }^{48}$ Para oito grupos de produtos as tarifas já eram originalmente zero.
} 
ao longo do ano. Os itens 2204.30.92, 2204.30.94 e 2204.30 .96 apresentaram duas tarifas específicas;

- os produtos hortícolas sofrem de quatro a oito tarifas sazonais no decorrer do ano, enquanto as frutas enfrentam de três a oito configurações tarifárias de acordo com a safra da Comunidade;

- $\quad$ em termos de correlação média entre o preço de entrada e a tarifa específica, todos os quatro grupos de produto apresentaram uma clara correlação negativa: $-69 \%$ nos produtos hortícolas, $-77 \%$ em frutas, $-71 \%$ no caso de preparações de hortícolas, e $60 \%$ para as alíneas de bebidas e vinagres.

Tais resultados encontram-se tabelados a seguir e a abertura das sazonalidades foi posta como anexo do texto. 
Tabela 22. Alíneas identificadas com tarifação sazonal e/ou preço de entrada.

\begin{tabular}{|c|c|c|c|c|}
\hline SH8 & Descrição & Sazonalidades & $\begin{array}{l}\text { Correlação } \\
\text { média } \\
(\%)\end{array}$ & $\begin{array}{c}\text { Correlação média } \\
\text { (itens do capítulo) } \\
(\%)\end{array}$ \\
\hline 0702.00 .00 & Tomates frescos ou congelados & 8 & -65 & \\
\hline 0707.00.05 & Pepinos & 7 & -70 & \\
\hline 0709.10.00 & Alcachofra & 4 & -72 & \\
\hline 0709.90 .70 & Abobrinha & 5 & -70 & -69 \\
\hline 0805.10 .10 & Laranja doce (Sanguinea) & 7 & -80 & \\
\hline 0805.10 .30 & Laranja doce (Hamlin) & 7 & -80 & \\
\hline 0805.10 .50 & Laranja doce (outras) & 7 & -78 & \\
\hline 0805.20 .10 & Clementina (híbrido de laranja) & 3 & -86 & \\
\hline 0805.20 .30 & Tangerina (Satsuma/Monreale) & 3 & -67 & \\
\hline 0805.20 .50 & Tangerina (Mandarin) & 3 & -67 & \\
\hline 0805.20 .70 & Tangerina & 3 & -67 & \\
\hline 0805.20 .90 & Tangerina (outras) & 3 & -67 & \\
\hline 0805.50 .10 & Limão & 6 & -68 & \\
\hline 0806.10 .10 & Uvas de mesa & 5 & -90 & \\
\hline 0808.10 .20 & Uvas (Golden Delicious) & 6 & -67 & \\
\hline 0808.10 .50 & Uvas (Granny Smith) & 6 & -67 & \\
\hline 0808.10 .90 & Uvas (outras) & 6 & -68 & \\
\hline 0809.10.00 & Damasco & 5 & -75 & \\
\hline 0809.20.05 & Cerejas amargas & 7 & -99 & \\
\hline 0809.20 .95 & Cerejas (outras) & 8 & -78 & \\
\hline 0809.30.10 & Pêssegos & 5 & -89 & \\
\hline 0809.30 .90 & Nectarinas (outras) & 5 & -86 & \\
\hline 0809.40.05 & Ameixa & 4 & -95 & -77 \\
\hline 2009.61.10 & Suco de uva ${ }^{1}$ & 1 & -60 & \\
\hline 2009.69.19 & Suco de uva (outro) & 1 & -60 & \\
\hline 2009.69 .51 & Suco de uva conc. ${ }^{1}$ & 1 & -100 & \\
\hline 2009.69 .59 & Suco de uva conc. (outro) & 1 & -65 & -71 \\
\hline 2204.30 .92 & $\begin{array}{l}\text { Suco de uva não fermentado conc. } \\
\text { Suco de uva não fermentado conc. }\end{array}$ & 1 & -59 & \\
\hline 2204.30 .94 & (outro) & 1 & -60 & \\
\hline 2204.30 .96 & $\begin{array}{l}\text { Suco de uva não fermentado conc. } \\
\text { Suco de uva não fermentado conc. }\end{array}$ & 1 & -61 & \\
\hline 2204.30 .98 & (outro) & 1 & -59 & -60 \\
\hline
\end{tabular}

${ }^{1}$ Refere-se a valor acima de 18 euros/100 kg de peso líquido.

\subsection{Teste de qui quadrado}

Tanto a estatística de qui quadrado como o coeficiente de Pearson sugeriram dependência entre intervalo tarifário (na definição de pico tarifário) e capítulo agrícola. 
Sob tal prisma, as tarifas estariam concentradas em diferentes intervalos tarifários conforme o capítulo agrícola em análise.

O coeficiente de Pearson, que em tese varia entre zero e um, resultou 0,681 . A estatística de qui quadrado foi calculada em 1.697,43, resultado superior ao valor crítico da distribuição teórica $(50,892)$ com $1 \%$ de probabilidade de erro ${ }^{49}$. Isso conduz à rejeição da hipótese de independência entre intervalo tarifário e capítulo de produtos, para tal nível de probabilidade de erro.

A distribuição de freqüência esperada (sob a hipótese de independência) mostrou-se bastante díspar face aos valores observados. Caso o grupo de produtos fosse independente do intervalo tarifário, todos os capítulos agrícolas teriam aproximadamente $49,1 \%$ de tarifas no intervalo [0\%;15\%[, $18,7 \%$ das tarifas no intervalo [15\%; 30\%[, $8,6 \%$ das tarifas no intervalo [30\%;45\%[, 5,7\% das tarifas no intervalo [45\%;60\%[, e

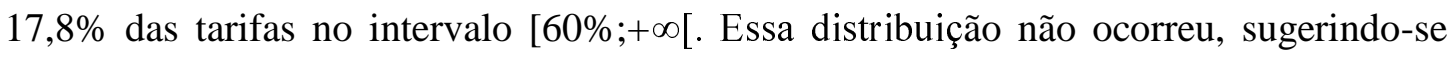
dependência entre grupo de produto e intervalo de tarifa.

Não obstante, como lembram Bussab \& Morettin (1987), por ser a distribuição de qui quadrado uma distribuição teórica aproximada e pelo fato de haver muitos valores inferiores a " 5 " na distribuição observada, é preciso tomar com cautela os resultados do coeficiente de Pearson e da estatística de qui quadrado. Segundo Lima \& Magalhães (2002), a aproximação para o modelo qui quadrado será melhor se todas as freqüências esperadas forem ao menos iguais a 5.

Portanto, os resultados desse ponto devem ser lidos não como ponto inapelável, mas como instrumento adicional de avaliação. A seguir constam as distribuições de freqüências observadas e esperadas.

\footnotetext{
${ }^{49}$ Pelas recomendações do teste o mesmo foi aplicado com 128 graus de liberdade.
} 
Tabela 23. Valores observados da distribuição tarifária.

\begin{tabular}{|c|c|c|c|c|c|c|}
\hline Capítulo/ Intervalo & $\begin{array}{l}{[0 \%} \\
15 \%[\end{array}$ & $\begin{array}{l}{[15 \%} \\
30 \%[\end{array}$ & $\begin{array}{c}{[30 \% ;} \\
45 \%[\end{array}$ & $\begin{array}{c}{[45 \%} \\
60 \%[\end{array}$ & $\begin{array}{c}{[60 \%} \\
+\infty[\end{array}$ & Alíneas \\
\hline Animais vivos $(01)$ & 38 & 3 & 2 & 0 & 11 & 54 \\
\hline Carnes e miudezas (02) & 62 & 37 & 27 & 28 & 77 & 231 \\
\hline Leite e laticínios (04) & 17 & 14 & 14 & 11 & 116 & 172 \\
\hline Outros itens de origem animal (05) & 21 & 0 & 0 & 0 & 0 & 21 \\
\hline Planta vivas e floricultura (06) & 42 & 0 & 0 & 0 & 0 & 42 \\
\hline Produtos hortícolas (07) & 89 & 12 & 0 & 0 & 6 & 107 \\
\hline Frutas (08) & 95 & 14 & 2 & 8 & 4 & 123 \\
\hline Café e mates (09) & 42 & 0 & 0 & 0 & 0 & 42 \\
\hline Cereais (10) & 20 & 2 & 3 & 1 & 27 & 53 \\
\hline Malte, amidos e féculas (11) & 23 & 14 & 20 & 16 & 8 & 81 \\
\hline Sementes e oleaginosos (12) & 74 & 1 & 0 & 0 & 0 & 75 \\
\hline Gomas e resinas vegetais (13) & 17 & 1 & 0 & 0 & 0 & 18 \\
\hline Matérias para entrançar (14) & 8 & 0 & 0 & 0 & 0 & 8 \\
\hline Óleos animais ou vegetais (15) & 113 & 2 & 3 & 2 & 5 & 125 \\
\hline Preparações de carne e peixes (16) & 18 & 12 & 1 & 1 & 13 & 45 \\
\hline Açúcares e confeitaria (17) & 13 & 3 & 4 & 3 & 24 & 47 \\
\hline Cacau e preparações (18) & 7 & 0 & 1 & 15 & 4 & 27 \\
\hline Preparações de cereais (19) & 4 & 13 & 8 & 6 & 16 & 47 \\
\hline Preparações hortícolas (20) & 69 & 178 & 32 & 15 & 15 & 309 \\
\hline Preparações alimentícias (21) & 30 & 4 & 3 & 2 & 3 & 42 \\
\hline Bebidas e vinagres (22) & 62 & 54 & 40 & 7 & 14 & 177 \\
\hline Resíduos de ind. Alimentares (23) & 38 & 4 & 3 & 0 & 18 & 63 \\
\hline Tabaco e manufaturados (24) & 1 & 13 & 11 & 2 & 3 & 30 \\
\hline Produtos químicos orgânicos (29) & 0 & 0 & 0 & 1 & 4 & 5 \\
\hline Óleos essenciais e resinóides (33) & 31 & 0 & 0 & 0 & 0 & 31 \\
\hline Matérias albuminóides e colas (35) & 19 & 4 & 2 & 0 & 0 & 25 \\
\hline Produtos diversos de ind. quím. (38) & 0 & 2 & 2 & 0 & 0 & 4 \\
\hline Peles e couros (41) & 19 & 0 & 0 & 0 & 0 & 19 \\
\hline Peleteria e suas obras (43) & 9 & 0 & 0 & 0 & 0 & 9 \\
\hline Seda $(50)$ & 4 & 0 & 0 & 0 & 0 & 4 \\
\hline Lã e pêlos finos ou grosseiros (51) & 17 & 0 & 0 & 0 & 0 & 17 \\
\hline Algodão (52) & 6 & 0 & 0 & 0 & 0 & 6 \\
\hline Outras fibras têxteis vegetais (53) & 7 & 0 & 0 & 0 & 0 & 7 \\
\hline Todos os itens & 1.015 & 387 & 178 & 118 & 368 & 2.066 \\
\hline
\end{tabular}


Tabela 24. Valores esperados da distribuição tarifária.

\begin{tabular}{|c|c|c|c|c|c|c|}
\hline Capítulo/ Intervalo & $\begin{array}{l}0 \% ; \\
15 \%[\end{array}$ & $\begin{array}{l}{[15 \% ;} \\
30 \%[\end{array}$ & $\begin{array}{l}{[30 \% ;} \\
45 \%[\end{array}$ & $\begin{array}{l}{[45 \% ;} \\
60 \%[\end{array}$ & $\begin{array}{l}{[60 \% ;} \\
+\infty[\end{array}$ & Alíneas \\
\hline Animais vivos $(01)$ & 27 & 10 & 5 & 3 & 10 & 54 \\
\hline Carnes e miudezas (02) & 113 & 43 & 20 & 13 & 41 & 231 \\
\hline Leite e laticínios (04) & 85 & 32 & 15 & 10 & 31 & 172 \\
\hline Outros itens de origem animal (05) & 10 & 4 & 2 & 1 & 4 & 21 \\
\hline Planta vivas e floricultura (06) & 21 & 8 & 4 & 2 & 7 & 42 \\
\hline Produtos hortícolas (07) & 53 & 20 & 9 & 6 & 19 & 107 \\
\hline Frutas (08) & 60 & 23 & 11 & 7 & 22 & 123 \\
\hline Café e mates (09) & 21 & 8 & 4 & 2 & 7 & 42 \\
\hline Cereais (10) & 26 & 10 & 5 & 3 & 9 & 53 \\
\hline Malte, amidos e féculas (11) & 40 & 15 & 7 & 5 & 14 & 81 \\
\hline Sementes e oleaginosos (12) & 37 & 14 & 6 & 4 & 13 & 75 \\
\hline Gomas e resinas vegetais (13) & 9 & 3 & 2 & 1 & 3 & 18 \\
\hline Matérias para entrançar (14) & 4 & 1 & 1 & 0 & 1 & 8 \\
\hline Óleos animais ou vegetais (15) & 61 & 23 & 11 & 7 & 22 & 125 \\
\hline Preparações de carne e peixes (16) & 22 & 8 & 4 & 3 & 8 & 45 \\
\hline Açúcares e confeitaria (17) & 23 & 9 & 4 & 3 & 8 & 47 \\
\hline Cacau e preparações (18) & 13 & 5 & 2 & 2 & 5 & 27 \\
\hline Preparações de cereais (19) & 23 & 9 & 4 & 3 & 8 & 47 \\
\hline Preparações hortícolas (20) & 152 & 58 & 27 & 18 & 55 & 309 \\
\hline Preparações alimentícias (21) & 21 & 8 & 4 & 2 & 7 & 42 \\
\hline Bebidas e vinagres (22) & 87 & 33 & 15 & 10 & 32 & 177 \\
\hline Resíduos de ind. Alimentares (23) & 31 & 12 & 5 & 4 & 11 & 63 \\
\hline Tabaco e manufaturados (24) & 15 & 6 & 3 & 2 & 5 & 30 \\
\hline Produtos químicos orgânicos (29) & 2 & 1 & 0 & 0 & 1 & 5 \\
\hline Óleos essenciais e resinóides (33) & 15 & 6 & 3 & 2 & 6 & 31 \\
\hline Matérias albuminóides e colas (35) & 12 & 5 & 2 & 1 & 4 & 25 \\
\hline Produtos diversos de ind. Quím. (38) & 2 & 1 & 0 & 0 & 1 & 4 \\
\hline Peles e couros $(41)$ & 9 & 4 & 2 & 1 & 3 & 19 \\
\hline Peleteria e suas obras (43) & 4 & 2 & 1 & 1 & 2 & 9 \\
\hline Seda $(50)$ & 2 & 1 & 0 & 0 & 1 & 4 \\
\hline Lã e pêlos finos ou grosseiros (51) & 8 & 3 & 1 & 1 & 3 & 17 \\
\hline Algodão (52) & 3 & 1 & 1 & 0 & 1 & 6 \\
\hline Outras fibras têxteis vegetais (53) & 3 & 1 & 1 & 0 & 1 & 7 \\
\hline Todos os itens & $\begin{array}{c}1.015 \\
(49,1 \%) \\
\end{array}$ & $\begin{array}{c}387 \\
(18,7 \%) \\
\end{array}$ & $\begin{array}{c}178 \\
(8,6 \%)\end{array}$ & $\begin{array}{c}118 \\
(5,7 \%) \\
\end{array}$ & $\begin{array}{c}368 \\
(17,8 \%) \\
\end{array}$ & $\begin{array}{c}2.066 \\
(100,0 \%) \\
\end{array}$ \\
\hline
\end{tabular}

\subsection{Indicador de Concentração por Capítulo (ICC)}

Esse indicador de proteção focaliza-se sobre o nível de dispersão tarifária para cada subgrupo de produtos, num universo de tarifas-pico. 
A tabela com os valores do indicador é exibida abaixo.

Tabela 25. Indicador de concentração por capítulo.

\begin{tabular}{lclc}
\hline \multicolumn{1}{c}{ Capítulo agrícola (SH) } & ICC & \multicolumn{1}{c}{ Capítulo agrícola (SH) } & ICC $^{1}$ \\
\hline Animais vivos (01) & 0,49 & Preparações de cereais (19) & 0,42 \\
Carnes e miudezas (02) & 1,65 & Preparações de hortícolas (20) & 0,37 \\
Leite e laticínios (04) & 0,75 & Preparações alimentícias (21) & 1,13 \\
Outros itens de origem animal (05) & n.d. & Bebidas e vinagres (22) & 0,83 \\
Planta vivas e floricultura (06) & n.d. & Resíduos de ind. Alimentares (23) & 6,20 \\
Produtos hortícolas (07) & 0,47 & Tabaco e manufaturados (24) & 0,33 \\
Frutas (08) & 1,65 & Produtos químicos orgânicos (29) & 0,46 \\
Café e mates (09) & n.d. & Óleos essenciais e resinóides (33) & n.d. \\
Cereais (10) & 0,42 & Matérias albuminóides e colas (35) & 0,13 \\
Malte, amidos e féculas (11) & 0,22 & Produtos diversos de ind. quím. (38) & 0,06 \\
Sementes e oleaginosos (12) & n.d. & Peles e couros (41) & n.d. \\
Gomas e resinas vegetais (13) & n.d. & Peleteria e suas obras (43) & n.d. \\
Matérias para entrançar (14) & n.d. & Seda (50) & n.d. \\
Óleos animais ou vegetais (15) & 0,84 & Lã e pêlos finos ou grosseiros (51) & n.d. \\
Preparações de carne e peixes (16) & 0,70 & Algodão (52) & n.d. \\
Açúcares e confeitaria (17) & 1,01 & Outras fibras têxteis vegetais (53) & n.d. \\
Cacau e preparações (18) & 0,56 & Todos os itens & 1,46 \\
\hline
\end{tabular}

${ }^{1}$ Houve 739 alíneas em que a tarifa EAV extraquota foi maior que $25 \%$.

Os números produzidos arremetem às seguintes considerações:

- o indicador não se definiu para os grupos de produtos sem registro de tarifa EAV acima de $25 \%$. Isso, por si só, já caracterizaria discriminação tarifária em relação aos produtos nos quais o indicador viu-se definido;

- em 10 categorias, o indicador esteve abaixo de 0,50: animais vivos, produtos hortícolas, cereais, malte, amido e féculas, preparações de cereais, preparações de hortícolas, tabaco e manufaturados, produtos químicos orgânicos, matérias albuminóides e colas e produtos diversos das indústrias químicas. 


\subsection{Picos tarifários}

Em relação às duas definições de pico tarifário adotadas, houve capítulos agrícolas que sempre apresentaram tarifas-pico em proporção maior que a do respectivo total da pauta.

Esse fenômeno verificou-se com carnes e miudezas, leite e laticínios, cereais, malte, amido e féculas, açúcares e confeitaria, cacau e preparações, preparações de cereais, bebidas e vinagres, tabaco e manufaturados, produtos químicos orgânicos e produtos diversos de indústrias químicas. 
Tabela 26. Picos tarifários entre os capítulos agrícolas.

\begin{tabular}{|c|c|c|c|c|}
\hline Capítulo agrícola $(\mathrm{SH})$ & $>25 \%$ & $\%$ nas alíneas do cap. & $>$ Mediana $(15 \%)$ & $\%$ nas alíneas do cap \\
\hline Animais vivos (01) & 13 & $24 \%$ & 16 & $30 \%$ \\
\hline Carnes e miudezas (02) & 136 & $59 \%$ & 169 & $73 \%$ \\
\hline Leite e laticínios (04) & 148 & $86 \%$ & 155 & $90 \%$ \\
\hline Outros itens de origem animal (05) & 0 & $0 \%$ & 0 & $0 \%$ \\
\hline Planta vivas e floricultura (06) & 0 & $0 \%$ & 0 & $0 \%$ \\
\hline Produtos hortícolas (07) & 6 & $6 \%$ & 18 & $17 \%$ \\
\hline Frutas $(08)$ & 16 & $13 \%$ & 28 & $23 \%$ \\
\hline Café e mates (09) & 0 & $0 \%$ & 0 & $0 \%$ \\
\hline Cereais (10) & 32 & $60 \%$ & 33 & $62 \%$ \\
\hline Malte, amidos e féculas (11) & 45 & $56 \%$ & 58 & $72 \%$ \\
\hline Sementes e oleaginosos (12) & 0 & $0 \%$ & 1 & $1 \%$ \\
\hline Gomas e resinas vegetais (13) & 0 & $0 \%$ & 1 & $6 \%$ \\
\hline Matérias para entrançar (14) & 0 & $0 \%$ & 0 & $0 \%$ \\
\hline Óleos animais ou vegetais (15) & 10 & $8 \%$ & 12 & $10 \%$ \\
\hline Preparações de carne e peixes (16) & 15 & $33 \%$ & 27 & $60 \%$ \\
\hline Açúcares e confeitaria (17) & 33 & $70 \%$ & 34 & $72 \%$ \\
\hline Cacau e preparações (18) & 20 & $74 \%$ & 20 & $74 \%$ \\
\hline Preparações de cereais (19) & 32 & $68 \%$ & 43 & $91 \%$ \\
\hline Preparações de hortícolas (20) & 91 & $29 \%$ & 236 & $76 \%$ \\
\hline Preparações alimentícias (21) & 9 & $21 \%$ & 12 & $29 \%$ \\
\hline Bebidas e vinagres (22) & 73 & $41 \%$ & 115 & $65 \%$ \\
\hline Resíduos de ind. Alimentares (23) & 21 & $33 \%$ & 25 & $40 \%$ \\
\hline Tabaco e manufaturados (24) & 27 & $90 \%$ & 29 & $97 \%$ \\
\hline Produtos químicos orgânicos (29) & 5 & $100 \%$ & 5 & $100 \%$ \\
\hline Óleos essenciais e resinóides (33) & 0 & $0 \%$ & 0 & $0 \%$ \\
\hline Matérias albuminóides e colas (35) & 4 & $16 \%$ & 6 & $24 \%$ \\
\hline Produtos diversos de ind. quím. (38) & 3 & $75 \%$ & 4 & $100 \%$ \\
\hline Peles e couros (41) & 0 & $0 \%$ & 0 & $0 \%$ \\
\hline Peleteria e suas obras (43) & 0 & $0 \%$ & 0 & $0 \%$ \\
\hline Seda $(50)$ & 0 & $0 \%$ & 0 & $0 \%$ \\
\hline Lã e pêlos finos ou grosseiros (51) & 0 & $0 \%$ & 0 & $0 \%$ \\
\hline Algodão (52) & 0 & $0 \%$ & 0 & $0 \%$ \\
\hline Outras fibras têxteis vegetais (53) & 0 & $0 \%$ & 0 & $0 \%$ \\
\hline Todos os itens & 739 & $36 \%$ & 1.047 & $51 \%$ \\
\hline
\end{tabular}


Graficamente, os produtos com maior participação de tarifas acima de $25 \%$ no total das respectivas alíneas ficaram como a seguir.

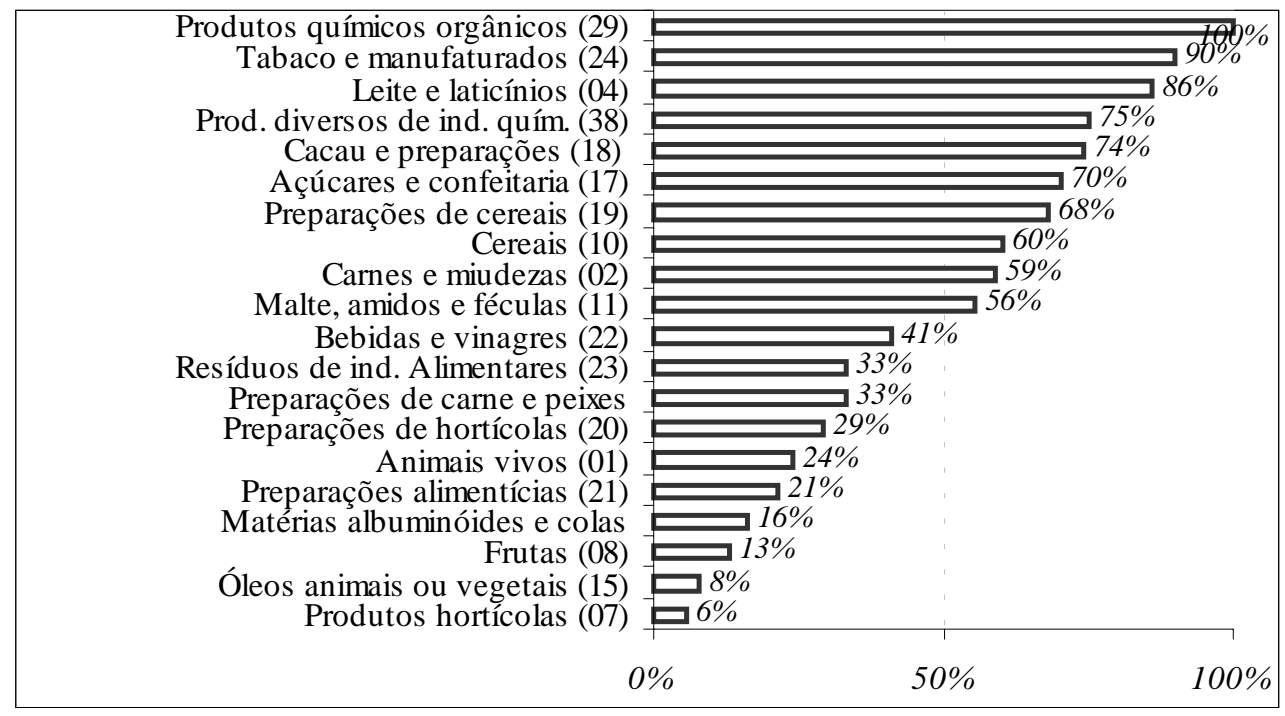

Figura 13 - Produtos com maior participação de tarifas pico.

1 Os grupos de produtos não exibidos na figura acima não apresentaram tarifa EAV extraquota acima de $25 \%$.

A observação simultânea desses produtos e daqueles nos quais o indicador de concentração por capítulo resultou menor que 0,50 aponta para seis grupos de produtos que são de fato alvo de tarifas proibitivas: cereais, malte, amidos e féculas, preparações de cereais, tabaco e manufaturados, produtos químicos orgânicos e produtos diversos de indústrias químicas.

\subsection{Quotas tarifárias}

Os resultados medidos nesse ponto estão ilustrados nas duas próximas tabelas. 
Tabela 27. Indicador de tarifa extraquota. (ITEQ)

\begin{tabular}{|c|c|c|c|}
\hline Capítulo agrícola $(\mathrm{SH})$ & ITEQ médio do cap. & Contra a média da pauta ${ }^{1}$ & Classificação (SH) \\
\hline Animais vivos (01) & 12,35 & 3,04 & Liderança em proteção \\
\hline Carnes e miudezas (02) & 3,48 & 0,86 & sob proteção \\
\hline Leite e laticínios (04) & 2,15 & 0,53 & sob proteção \\
\hline Produtos hortícolas (07) & 5,06 & 1,25 & Liderança em proteção \\
\hline Frutas (08) & 7,47 & 1,84 & Liderança em proteção \\
\hline Cereais (10) & 3,39 & 0,83 & sob proteção \\
\hline Preparações de carne e peixes (16) & 2,00 & 0,49 & sob proteção \\
\hline Açúcares e confeitaria (17) & 3,72 & 0,92 & sob proteção \\
\hline Preparações de hortícolas (20) & 2,78 & 0,68 & sob proteção \\
\hline Resíduos de ind. Alimentares (23) & 1,73 & 0,42 & sob proteção \\
\hline Matérias albuminóides e colas (35) & 2,01 & 0,49 & sob proteção \\
\hline
\end{tabular}

1 O ITEQ médio da pauta, calculado com as alíneas nas quais o indicador viu-se definido, resultou 4,03 .

Tabela 28. Extraquota positiva e intraquota nula.

\begin{tabular}{lcclcc}
\hline & & $\%$ no & & $\%$ no \\
Capítulo agrícola (SH) & Itens & cap. & \multicolumn{1}{c}{ Capítulo agrícola (SH) } & Itens & cap. \\
\hline Animais vivos (01) & 0 & 0 & Preparações de cereais (19) & 0 & 0 \\
Carnes e miudezas (02) & 31 & 13 & Preparações de hortícolas (20) & 0 & 0 \\
Leite e laticínios (04) & 0 & 0 & Preparações alimentícias (21) & 0 & 0 \\
Outros itens de origem animal (05) & 0 & 0 & Bebidas e vinagres (22) & 0 & 0 \\
Planta vivas e floricultura (06) & 0 & 0 & Resíduos de ind. Alimentares (23) & 0 & 0 \\
Produtos hortícolas (07) & 1 & 1 & Tabaco e manufaturados (24) & 0 & 0 \\
Frutas (08) & 3 & 2 & Produtos químicos orgânicos (29) & 0 & 0 \\
Café e mates (09) & 0 & 0 & Óleos essenciais e resinóides (33) & 0 & 0 \\
Cereais (10) & 20 & 38 & Matérias albuminóides e colas (35) & 0 & 0 \\
Malte, amidos e féculas (11) & 1 & 1 & Produtos diversos de ind. quím. (38) & 0 & 0 \\
Sementes e oleaginosos (12) & 0 & 0 & Peles e couros (41) & 0 & 0 \\
Gomas e resinas vegetais (13) & 0 & 0 & Peleteria e suas obras (43) & 0 & 0 \\
Matérias para entrançar (14) & 0 & 0 & Seda (50) & 0 & 0 \\
Óleos animais ou vegetais (15) & 0 & 0 & Lã e pêlos finos ou grosseiros (51) & 0 & 0 \\
Preparações de carne e peixes (16) & 0 & 0 & Algodão (52) & 0 & 0 \\
Açúcares e confeitaria (17) & 6 & 13 & Outras fibras têxteis vegetais (53) & 0 & 0 \\
Cacau e preparações (18) & 0 & 0 & Todos os itens & 62 & 3 \\
\hline
\end{tabular}

Dentre os 33 grupos de produtos avaliados, 11 apresentaram a incidência de quotas tarifárias, totalizando 253 alíneas num universo de 2.066 produtos. A simples estruturação do mecanismo de quotas tarifárias nesses capítulos agrícolas informa que eles são mais protegidos no mercado doméstico da UE. Nesses termos, o indicador de 
tarifa extraquota identificou os setores de animais vivos, produtos hortícolas e frutas como líderes em proteção no contexto de quotas tarifárias.

Além disso, os capítulos agrícolas foram mapeados em termos da existência de tarifas extraquota positivas com tarifa de $0 \%$ até o volume de preenchimento da quota. Esse fenômeno é particularmente prejudicial nos casos de carnes e miudezas, cereais e açúcares e confeitaria.

Uma peculiaridade nesse ponto é que nos casos em que as tarifas intraquota e extraquota são definidas diferentemente (ad valorem e específica, por exemplo), o preço de referência utilizado pode gerar uma tarifa extraquota inferior à tarifa intraquota.

\subsection{Estimativas de suporte}

A queda ou crescimento do coeficiente nominal de suporte e os resultados fundamentais das regressões dessa variável contra o tempo compõem a tabela imediatamente seguinte nos produtos mencionados pelo indicador da OCDE, permitindo-se alguns comentários.

O primeiro ponto a observar é que os coeficientes de explicação das equações variaram consideravelmente de acordo com os produtos.

Houve nove casos em que o modelo linear simples em função do tempo explicou cerca de $50 \%$ ou mais da variação total no coeficiente nominal de suporte ao longo do período analisado. Para trigo duro, aveia, arroz, oleaginosas, soja, colza, semente de girassol, carne bovina e carne caprina, o modelo empregado, ainda que simples, captou parte da mudança no suporte à agricultura comunitária, incluídas as reformas da PAC em 1992 e 2000. Já nos casos de trigo, cevada e outros grãos, por exemplo, o ajuste foi bastante pobre.

Em relação aos interceptos, resultaram estatisticamente significantes e, à exceção de aveia, carne suína e ovos, claramente acima da unidade. Convém lembrar que o valor "1" corresponderia à ausência de política de suporte já em 1986 
No caso de trigo duro, aveia e carnes suína, bovina e de aves, notou-se tanto um aumento do nível de suporte como uma tendência de crescimento do mesmo ao longo do período observado. Para esses produtos, há um aparente acirramento das políticas de intervenção praticadas pela UE.

É de se notar também que há produtos para os quais o coeficiente estimado para a variável tendência não pode ser rejeitado como estatisticamente diferente de zero. Isso ocorreu com trigo, trigo comum, outros grãos, cevada e açúcar refinado. Nesses casos, não se pode dizer que o tempo decorrido entre 1986 e 2002 explique a variação sofrida pelo coeficiente nominal de suporte.

Todavia, em todos esses casos, o intercepto estimado foi maior que 1 e o declínio entre o nível de suporte da média do período 1986/88 para a média do período 2000/02 nunca foi maior que 24\%. Isto é, nesses produtos, é razoável supor que o agricultor comunitário ainda é remunerado em condições (de suporte) substancialmente mais vantajosas que sob os preços de fronteira ou dos respectivos mercados mundiais.

Por fim, nos demais produtos, o coeficiente estimado para a variável tempo foi negativo e significante estatisticamente. Para os casos da carne caprina, arroz, oleaginosas, soja, colza e semente de girassol, os coeficientes estimados são de magnitude a ratificar quedas significativas nos níveis de suporte a partir de 1986. Em itens de potencial interesse para o Brasil, como milho e lácteos, também se nota uma tendência de queda de suporte ao longo do período, porém de forma menos marcante.

Assim, aproximativamente, em termos da nomenclatura do $\mathrm{SH}$, há produtos ainda sob nítida política de apoio na agricultura da UE, ou seja, carnes e miudezas, leite e laticínios, cereais, malte, amidos e féculas, preparações de carne e peixes, açúcares e confeitaria, preparações de cereais e preparações alimentícias. 
Tabela 29. Resultados de mensuração das estimativas de suporte.

\begin{tabular}{lcccccc}
\hline \multicolumn{1}{c}{ Produto } & $\begin{array}{c}(2002 / 00) / \\
(1986 / 88)(\%)\end{array}$ & $\mathrm{R}^{2}(\%)$ & $\begin{array}{c}\text { Coef. } \\
\text { intercepto }\end{array}$ & $\begin{array}{c}\text { Stat t } \\
\text { intercepto }\end{array}$ & $\begin{array}{c}\text { Coef. } \\
\text { tempo }\end{array}$ & $\begin{array}{c}\text { Stat t } \\
\text { tempo }\end{array}$ \\
\hline Trigo & 90 & 1,03 & 1,935 & 13,511 & $-0,006$ & $-0,394$ \\
Trigo comum & 82 & 6,93 & 1,931 & 12,737 & $-0,016$ & $-1,057$ \\
Trigo duro & 141 & 73,80 & 2,011 & 21,479 & 0,059 & 6,500 \\
Grãos para ração & 72 & 18,54 & 2,288 & 13,048 & $-0,032$ & $-1,848$ \\
Outros grãos & 84 & 0,00 & 2,269 & 8,715 & 0,001 & 0,025 \\
Milho & 71 & 48,16 & 2,222 & 18,406 & $-0,044$ & $-3,733$ \\
Cevada & 76 & 2,37 & 2,432 & 8,744 & $-0,016$ & $-0,603$ \\
Aveia & 184 & 60,70 & 1,148 & 4,097 & 0,132 & 4,813 \\
Arroz & 64 & 62,84 & 2,598 & 16,785 & $-0,076$ & $-5,036$ \\
Oleaginosas & 63 & 77,96 & 2,702 & 23,504 & $-0,082$ & $-7,285$ \\
Soja & 59 & 49,56 & 3,064 & 11,603 & $-0,099$ & $-3,839$ \\
Colza & 70 & 66,09 & 2,777 & 20,267 & $-0,072$ & $-5,407$ \\
Semente de girassol & 71 & 74,67 & 2,713 & 26,117 & $-0,067$ & $-6,650$ \\
Açúcar refinado & 76 & 13,64 & 2,386 & 13,563 & $-0,026$ & $-1,539$ \\
Lácteos & 75 & 44,00 & 2,551 & 21,955 & $-0,039$ & $-3,433$ \\
Carne bovina & 168 & 49,53 & 1,656 & 5,556 & 0,112 & 3,837 \\
Carne suína & 109 & 28,29 & 1,067 & 18,632 & 0,014 & 2,433 \\
Carne de aves & 120 & 21,73 & 1,406 & 15,778 & 0,018 & 2,041 \\
Carne caprina & 55 & 66,95 & 3,855 & 17,525 & $-0,118$ & $-5,512$ \\
Ovos & 90 & 31,53 & 1,159 & 42,458 & $-0,007$ & $-2,628$ \\
\hline
\end{tabular}

Nota: os valores críticos da distribuição $t$ de Student para $5 \%$ e $10 \%$ de probabilidade de erro foram, respectivamente, 2,131 e 1,753.

\subsection{Oferta agrícola da UE}

A oferta agrícola redefinida pela UE em 2003 apresentou 24\% de seus 2.137 itens no anexo A da oferta, $11 \%$ no anexo B, $10 \%$ no anexo C, $11 \%$ no anexo D e $44 \%$ no anexo E. Isso implica que quase 55\% dos produtos citados levariam 10 anos ou um tempo indeterminado para a zeragem de suas tarifas ad valorem, intocadas as tarifas específicas ou mistas quando presentes.

Ao mesmo tempo, os produtos do anexo A contabilizam a quase totalidade dos produtos agrícolas cuja tarifa NMF extraquota já é de $0 \%$.

Como terceiro agravante, é preciso citar que em todos os casos mantém-se em vigor o sistema de preços de entrada. 
Esses pontos ilustram o caráter discriminatório da proposta, inclusive porque os itens do anexo E reúnem não por acaso os produtos sujeitos a adicional tarifário por presença de açúcar, farinha ou outro componente agrícola ou industrial, bem como a quase totalidade de produtos sujeitos a tarifação específica.

Segundo a UE, os produtos sujeitos a tarifas específicas ou mistas poderiam vir a gozar de maior liberalização através da concessão progressiva de quotas tarifárias preferenciais ao Mercosul. Todavia, esse é um ponto cuja negociação está em transcurso.

Entre os grupos de produto com 5\% ou mais de participação em ao menos um dos anexos, citam-se o caso de carnes e miudezas, leite e laticínios, frutas, cereais, malte, amidos e féculas, preparações de carne e peixes, preparações de cereais, preparações de hortícolas e bebidas e vinagres.

Em termos práticos, a distribuição de produtos nos anexos D e E ficou como a seguir. 
Tabela 30. Participação dos grupos de produtos nos anexos D e E.

\begin{tabular}{|c|c|c|c|c|}
\hline Capítulo agrícola (SH) & $\begin{array}{l}\text { Itens no } \\
\text { anexo D }\end{array}$ & $\begin{array}{c}\text { Part. \% no } \\
\text { anexo D }\end{array}$ & $\begin{array}{l}\text { Itens no } \\
\text { anexo E }\end{array}$ & $\begin{array}{c}\text { Part. \% no } \\
\text { anexo E }\end{array}$ \\
\hline Animais vivos (01) & 0 & 0,0 & 30 & 3,2 \\
\hline Carnes e miudezas (02) & 10 & 4,3 & 169 & 18,0 \\
\hline Leite e laticínios (04) & 1 & 0,4 & 166 & 17,7 \\
\hline Outros itens de origem animal (05) & 0 & 0,0 & 0 & 0,0 \\
\hline Planta vivas e floricultura (06) & 0 & 0,0 & 0 & 0,0 \\
\hline Produtos hortícolas (07) & 2 & 0,9 & 14 & 1,5 \\
\hline Frutas $(08)$ & 18 & 7,7 & 5 & 0,5 \\
\hline Café e mates (09) & 0 & 0,0 & 0 & 0,0 \\
\hline Cereais (10) & 0 & 0,0 & 47 & 5,0 \\
\hline Malte, amidos e féculas (11) & 1 & 0,4 & 77 & 8,2 \\
\hline Sementes e oleaginosos (12) & 0 & 0,0 & 3 & 0,3 \\
\hline Gomas e resinas vegetais (13) & 0 & 0,0 & 2 & 0,2 \\
\hline Matérias para entrançar (14) & 0 & 0,0 & 0 & 0,0 \\
\hline Óleos animais ou vegetais (15) & 2 & 0,9 & 10 & 1,1 \\
\hline Preparações de carne e peixes (16) & 12 & 5,1 & 15 & 1,6 \\
\hline Açúcares e confeitaria (17) & 0 & 0,0 & 46 & 4,9 \\
\hline Cacau e preparações (18) & 0 & 0,0 & 21 & 2,2 \\
\hline Preparações de cereais (19) & 0 & 0,0 & 49 & 5,2 \\
\hline Preparações de hortícolas (20) & 177 & 75,6 & 75 & 8,0 \\
\hline Preparações alimentícias (21) & 0 & 0,0 & 27 & 2,9 \\
\hline Bebidas e vinagres (22) & 1 & 0,4 & 123 & 13,1 \\
\hline Resíduos de ind. Alimentares (23) & 0 & 0,0 & 32 & 3,4 \\
\hline Tabaco e manufaturados (24) & 10 & 4,3 & 9 & 1,0 \\
\hline Produtos químicos orgânicos (29) & 0 & 0,0 & 5 & 0,5 \\
\hline Óleos essenciais e resinóides (33) & 0 & 0,0 & 0 & 0,0 \\
\hline Matérias albuminóides e colas (35) & 0 & 0,0 & 10 & 1,1 \\
\hline Produtos diversos de ind. quím. (38) & 0 & 0,0 & 4 & 0,4 \\
\hline Peles e couros (41) & 0 & 0,0 & 0 & 0,0 \\
\hline Peleteria e suas obras (43) & 0 & 0,0 & 0 & 0,0 \\
\hline Seda (50) & 0 & 0,0 & 0 & 0,0 \\
\hline Lã e pêlos finos ou grosseiros (51) & 0 & 0,0 & 0 & 0,0 \\
\hline Algodão (52) & 0 & 0,0 & 0 & 0,0 \\
\hline Outras fibras têxteis vegetais (53) & 0 & 0,0 & 0 & 0,0 \\
\hline Todos os itens & 234 & 100,0 & 939 & 100,0 \\
\hline
\end{tabular}

\subsection{Proteção conjunta}

No que diz respeito aos instrumentos de proteção mantidos pela União Européia, destacam-se os seguintes pontos principais: 
Em primeiro lugar, a simultaneidade de instrumentos de proteção no caso de carnes e miudezas, leite e laticínios, cereais, preparações de carne e peixes e açúcares e confeitaria. Observa-se a coincidência de distintos instrumentos de política comercial tendo esses grupos de produtos como objeto.

Além disso, há significativa proporção de tarifas específicas (mais de 50\% das respectivas alíneas) em animais vivos, carnes e miudezas, leite e laticínios, cereais, malte, amidos e féculas, açúcares e confeitaria, cacau e preparações, preparações de cereais, bebidas e vinagres e tabaco e manufaturados.

No caso de produtos químicos orgânicos e de produtos diversos das indústrias químicas, há um reduzido número de alíneas consideradas agrícolas, mas todas elas detêm a presença do mecanismo de gatilhos e de tarifas específicas.

Ademais, são também bastante gravados pelo mecanismo de gatilhos $(S S G$ s) os grupos de leite e laticínios, malte, amidos e féculas, açúcares e confeitaria e resíduos de indústrias alimentares.

Por fim, o elemento talvez mais surpreendente seja o uso alternado de instrumentos que se sobrepõem numa estrutura de proteção tarifária que pode ser menos onerosa sob certo aspecto, mas que se mostra proibitiva em outros.

Isso tudo sem dizer que em produtos como frutas, produtos hortícolas, bebidas e vinagres e tabaco e manufaturados a eventual estrutura de apoio doméstico da PAC não é sequer medida pelo indicador da OCDE que se utilizou. Sob tais circunstâncias, a proteção total nesses produtos pode ser algo maior do que a retratada pela análise do coeficiente nominal de suporte.

Em termos dos capítulos agrícolas discriminados na oferta agrícola da UE, e para uma visualização da incidência conjunta de políticas de suporte, tarifação sazonal, proporção de alíneas sob $T R Q^{\prime}$ s, sob mecanismo de gatilhos ( $S S G^{\prime}$ s) e sob tarifa especifica ou mista observe-se a tabela a seguir. 
Tabela 31. Proteção conjunta por diversos instrumentos. ${ }^{1}$

\begin{tabular}{|c|c|c|c|c|c|c|}
\hline Capítulo agrícola (SH) & $\begin{array}{l}T R Q^{\prime} \mathrm{s} \\
(\%)\end{array}$ & $\begin{array}{l}S S G^{\prime} \mathrm{s} \\
(\%)\end{array}$ & $\begin{array}{l}\mathrm{TE} \\
(\%)\end{array}$ & Tarifa sazonal & CNS & Oferta agrícola \\
\hline Animais vivos $(01)$ & 15 & 15 & 54 & & & \\
\hline Carnes e miudezas (02) & 42 & 26 & 73 & & $\mathrm{X}$ & $\mathrm{X}$ \\
\hline Leite e laticínios (04) & 32 & 52 & 95 & & $\mathrm{X}$ & $\mathrm{X}$ \\
\hline Outros itens de origem animal (05) & 0 & 0 & 0 & & & \\
\hline Planta vivas e floricultura (06) & 0 & 0 & 0 & & & \\
\hline Produtos hortícolas (07) & 12 & 11 & 21 & $X$ & & \\
\hline Frutas $(08)$ & 11 & 0 & 19 & $X$ & & $X$ \\
\hline Café e mates (09) & 0 & 0 & 0 & & & \\
\hline Cereais (10) & 57 & 19 & 85 & & $\mathrm{X}$ & $\mathrm{X}$ \\
\hline Malte, amidos e féculas (11) & 2 & 43 & 93 & & $\mathrm{X}$ & $\mathrm{X}$ \\
\hline Sementes e oleaginosos (12) & 0 & 0 & 1 & & & \\
\hline Gomas e resinas vegetais (13) & 0 & 0 & 0 & & & \\
\hline Matérias para entrançar (14) & 0 & 0 & 0 & & & \\
\hline Óleos animais ou vegetais (15) & 0 & 8 & 8 & & & \\
\hline Preparações de carne e peixes (16) & 22 & 24 & 33 & & $\mathrm{X}$ & $\mathrm{X}$ \\
\hline Açúcares e confeitaria (17) & 17 & 49 & 94 & & $\mathrm{X}$ & \\
\hline Cacau e preparações (18) & 0 & 0 & 74 & & & \\
\hline Preparações de cereais (19) & 0 & 2 & 96 & & $\mathrm{X}$ & $\mathrm{X}$ \\
\hline Preparações hortícolas (20) & 3 & 1 & 24 & $\mathrm{X}$ & & $\mathrm{X}$ \\
\hline Preparações alimentícias (21) & 0 & 10 & 40 & & $\mathrm{X}$ & \\
\hline Bebidas e vinagres (22) & 0 & 0 & 67 & $\mathrm{X}$ & & $\mathrm{X}$ \\
\hline Resíduos de ind. Alimentares (23) & 11 & 48 & 46 & & & \\
\hline Tabaco e manufaturados (24) & 0 & 0 & 70 & & & \\
\hline Produtos químicos orgânicos (29) & 0 & 100 & 100 & & & \\
\hline Óleos essenciais e resinóides (33) & 0 & 0 & 0 & & & \\
\hline Matérias albuminóides e colas (35) & 8 & 24 & 40 & & & \\
\hline $\begin{array}{l}\text { Produtos diversos de ind. Quím. } \\
\text { (38) }\end{array}$ & 0 & 100 & 100 & & & \\
\hline Peles e couros (41) & 0 & 0 & 0 & & & \\
\hline Peleteria e suas obras (43) & 0 & 0 & 0 & & & \\
\hline Seda $(50)$ & 0 & 0 & 0 & & & \\
\hline Lã e pêlos finos ou grosseiros (51) & 0 & 0 & 0 & & & \\
\hline Algodão (52) & 0 & 0 & 0 & & & \\
\hline Outras fibras têxteis vegetais (53) & 0 & 0 & 0 & & & \\
\hline Todos itens & 12 & 15 & 45 & & & \\
\hline
\end{tabular}

1 O símbolo \% implica dizer a proporção de alíneas no capítulo ou no conjunto de alíneas agrícolas do capítulo gravadas por aquele instrumento de política comercial. 


\section{CONCLUSÕES E RECOMENDAÇÕES DE POLÍTICA}

Os temas comércio internacional e negociações comerciais ganharam renovada importância ao fim da Rodada do Uruguai e com o esvaziamento da Guerra Fria. Nesse processo, os estudos e a sedimentação de conhecimento em torno das questões correlatas são ainda um movimento em curso, ao mesmo tempo em que a dinâmica do processo negociador é quase que diária, assim como o freqüente manuseio dos instrumentos de política comercial pelos países.

Durante a revisão teórica, a maioria dos trabalhos visitados nesse estudo reporta a PAC como uma política de suporte que se apóia em elevados preços de importações para tornar seus preços garantidos internamente factíveis, definindo-se tarifas NMF maiores que a distância entre os preços internos da UE e os preços mundiais. Esse fato foi citado naqueles setores que (não por acaso) também foram referidos como os concentradores de recursos nos gastos de intervenção da Política.

A discussão teórica acerca da trajetória de evolução da PAC permite concluir dois pontos principais. Por um lado, as reformas até aqui divulgadas foram basicamente uma parcial substituição dos mecanismos de preços garantidos pelos pagamentos diretos, inalteradas as estruturas tarifárias. O efeito disso tem sido a geração de elevados níveis de produção e a manutenção de fôlego competitivo dos produtores comunitários através da capitalização das respectivas unidades produtivas.

Como segundo elemento, é razoável a idéia de que as políticas comerciais e os mecanismos de intervenção da PAC somente se sustentam quando manejados simultaneamente e de forma concatenada aos objetivos pré-definidos em Bruxelas. E é 
nessa combinação de instrumentos que a UE consegue promover $\mathrm{p}$ reços internos descolados dos preços mundiais.

Além disso, os trabalhos de modelagem apresentados na revisão teórica sugerem que o Brasil seria um dos beneficiados com o arrefecimento das políticas de suporte da PAC e com a redução das tarifas agrícolas da UE, seja pelo ganho de acesso àquele mercado como pelo aumento dos preços mundiais em setores como açúcar, lácteos, ovos e carnes bovina, suína e de aves.

Acerca da discriminação tarifária, resultados anteriores de medições da pauta da UE destacaram carnes e miudezas, lácteos, cereais, açúcares e preparações de carne e peixes como os grupos de produtos agrícolas mais protegidos na União Européia.

A medição da pauta tarifária da UE incidente sobre os produtos agrícolas exportados pelo Brasil resultou uma tarifa média simples de $37 \%$ e numa tarifa média ponderada de $53 \%$, além da identificação de um elevado nível de dispersão tarifária.

Vários foram os elementos que captaram a existência de discriminação tarifária da UE entre os grupos de produtos analisados, com base exclusivamente nos resultados do presente trabalho.

O teste de qui quadrado, por exemplo, sugeriu a existência de dependência entre uma definição relevante de intervalo tarifário (no caso, a de pico tarifário) e os grupos de produtos.

As simulações de tarifas com distintos preços de referência confirmaram a vigência de um elevado patamar de proteção tarifária em nichos de produtos, conquanto grande parte das tarifas estimadas seja relativamente reduzida. Particularmente o uso dos preços de exportação Brasileiros gerou o maior descolamento entre a tarifa média ponderada e a tarifa média simples, no contexto da pauta agregada. 
Ademais, a aplicação de diferentes preços de referência gerou perfis tarifários razoavelmente desiguais. Do ponto de vista dos interesses desse estudo, os preços de exportação Brasileiros mostraram-se os mais adequados.

A consolidação das tarifas com esses preços de conversão possibilitou identificar os subgrupos de produtos agrícolas e/ou agrícolas processados Brasileiros sujeitos à nítida restrição e/ou discriminação de acesso ao mercado comunitário da União Européia.

A análise conjunta dessa base de tarifas e das medidas efetuadas em termos de picos tarifários, quotas tarifárias, mecanismo de gatilhos, estimativas de suporte e discriminação pela oferta agrícola possibilitou reconhecer os produtos mais penalizados dentre os 33 grupos de produtos avaliados.

Em primeiro plano, carnes e miudezas, leite e laticínios, cereais, preparações de carne e peixes, açúcares e confeitaria, preparações de cereais e tabaco e manufaturados. Um segundo subgrupo, que também deve ser destacado contemplou malte, amidos e féculas, cacau e preparações, resíduos de indústrias alimentares e produtos químicos orgânicos.

O mecanismo de tarifa sazonal foi reconhecido como instrumento de controle fino no acesso das importações de produtos hortícolas, frutas, preparações de hortícolas e bebidas e vinagres.

Pela definição de agricultura empregada, embora se referindo a poucas alíneas tarifárias, os produtos químicos orgânicos e os produtos diversos das indústrias químicas mostraram-se objeto dos mecanismos de gatilhos e das tarifas específicas.

As restrições tarifárias foram menores e/ou dispersas entre os vários instrumentos de política comercial tarifária da União Européia no caso dos grupos de produtos não citados. 
Em particular a discussão em termos de suporte doméstico é mais complexa. Tanto porque os lobbies agrícolas do mundo desenvolvido ocupam-se especialmente em defender suas políticas de apoio, como pelo fato de que Estados Unidos e União Européia insistem em só discutir subsídios no fórum multilateral. Nesse espaço de negociação, o Brasil precisa necessariamente fazer concessões em outras áreas (industrial, serviços ou patentes, por exemplo) para angariar aliados que também advoguem por uma redução verdadeira nos níveis de apoio. Esse processo passa tanto pela clara definição de prioridades internas no processo negociador Brasileiro como pela manutenção de alianças estratégicas no cenário internacional, componentes nada triviais.

Em termos globais, pode-se concluir que a proteção tarifária agrícola na Europa unificada é uma proteção tarifária seletiva, inteligente e concebida de acordo com interesses internos bem definidos. Esse não deve ser um fato novo, mas já em vigor desde os anos em que o Brasil pouco se ocupava de estudos relacionados ao tema.

Isso posto, é preciso deixar anotadas recomendações de política que podem ser vislumbradas a partir das conclusões acima. Nesse contexto, ficam sugeridas recomendações específicas para os principais pontos analisados.

Ex ante e desde sempre, o negociador Brasileiro deve olhar os grupos de produtos acima destacados com particular carinho e atenção, seja na troca de futuras ofertas no fórum biregional Mercosul-UE seja no âmbito da OMC. Propostas que desconsiderem reduções tarifárias significativas nesses grupos de bens não constituirão ganhos substanciais em relação às vantagens comparativas do Brasil em agricultura e agroindústria.

No campo dos picos tarifários, como a maioria das tarifas proibitivas está associada à presença de uma tarifa específica, é importante que as reduções tarifárias futuras incluam esse elemento, diferentemente da proposta do bloco europeu feita em 2001 e quase que literalmente reeditada em 2003. 
No caso das quotas tarifárias, seria desejável a expansão dos volumes originas das quotas sem especificar que a quota tarifária ou sua expansão seja destinada a certos países ou grupos de importadores/exportadores. Em verdade, para as características competitivas do Brasil em agricultura, o fato realmente desejável seria o desmantelamento do sistema de quotas tarifárias da UE. Entretanto, esse é um fato tão desejado quanto improvável no curto prazo.

Nesse momento, o próprio Mercosul negocia quotas tarifárias de acesso preferencial em alguns desses produtos; situação para o Brasil ficar atento aos volumes negociados, às tarifas atreladas a tais volumes e aos métodos de administração definidos para essas quotas tarifárias.

Aliás, no que respeita às negociações de integração comercial entre Mercosul e União Européia a oferta agrícola feita pela UE em 2001 foi apenas marginalmente melhorada em sua reapresentação em 2003. Qualitativamente, a existência dos anexos D e E e o grande número de tarifas específicas - sem prévio horizonte de redução - no anexo E sinalizam uma pequena disposição a ceder da parte da UE.

Portanto, cabe ao negociador Brasileiro uma nova demanda por melhoria na proposta de redução tarifária nos produtos que compõem os anexos D e E, incluída uma metodologia de cortes nas tarifas específicas, sem o que qualquer (re)proposta torna-se inócua para os interesses Brasileiros.

Enquanto estratégia contínua, de alguns anos para cá o Brasil mantém uma missão diplomática fixa em Bruxelas (a Missão Permanente junto às Comunidades Européias) e já existe um certo número de estudos dedicados a entender a natureza da proteção tarifária na UE. Assim, cumpre aprofundar e atualizar permanentemente o conhecimento no assunto, dada sua aplicabilidade tanto nas negociações bilaterais quanto na avaliação das propostas feitas no âmbito da OMC. 
À feição da dinâmica negociadora, o correto e equilibrado conhecimento das questões nessa área demanda um trabalho intenso e de médio/longo prazo. Ainda que o respectivo expertise Brasileiro tenha ganho fôlego inegável no passado recente, a discussão feita no seio da sociedade Brasileira ainda é conduzida de forma difusa e ideológica.

A partir desses componentes, somente uma postura com os olhos voltados para o longo prazo pode fazer da composição de interesses Brasileiros afetados uma sinfonia bem orquestrada, cujos acordes finais representem ganho de acesso a mercado, melhoria do saldo da balança comercial e crescimento dos respectivos emprego e produção domésticos.

Para finalizar, fica anotada a sugestão de estudos setoriais ou por grupos de produtos em pesquisas futuras, sobretudo em termos dos setores do agronegócio Brasileiro relativamente discriminados.

De um lado, estudos nessa direção poderão refinar ou rebater as conclusões aqui delineadas ao aproximarem-se das realidades específicas de produção e consumo dos mercados importadores e mundial face à capacidade exportadora Brasileira. No limite, é preciso não apenas negociar tarifas mais baixas, mas também aprimorar canais de transporte e distribuição no interior do bloco europeu.

De outro lado, tais trabalhos - bem como este que se apresenta - podem servir como informação atualizada e insumo necessário à implementação de outras ferramentas de avaliação como os modelos de equilíbrio geral e parcial, possibilitandose novas simulações e cenários acerca dos ganhos que o Brasil obteria em função de um maior ingresso de seus produtos agrícolas e agrícolas processados no mercado consumidor da UE. 
ANEXOS 


\section{ANEXO A}

Esse anexo apresenta os procedimentos adotados no caso das alíneas tarifárias submetidas a complexidades técnicas ou a regras de interpretação. Na ausência de operações reais de exportação, essas alíneas só puderam ser calculadas com a adoção de certas hipóteses.

Em cada situação são apresentados três elementos: a característica daquele código tarifário, o procedimento adotado e as linhas tarifárias enquadradas no respectivo contexto. No total, foram contabilizadas 16 descrições tarifárias que representam particularidades da estrutura de tarifas agrícolas da União Européia. Como a seguir:

1 Casos que dependem da quantidade de matéria-prima láctea presente. Supôs-se 1,00 Kg (ou 1 litro no caso de 2307.00.19 e 2307.00.90) em $100 \mathrm{Kg}$ do produto final. Ex.: 0402.10.91: 1,19 Euro/kg + 27,5 Euro/100 kg/net 0402.10.99: 1,19 Euro/kg + 21 Euro/100 kg/net

Idem para: 0402.29.11, 0402.29.15, 0402.29.19, 0402.29.99, 0402.99.31, 0402.99.39, 0402.99.99, 0403.10.31, 0403.10.33, 0403.10.39, 0403.90.61, 0403.90.63, 0403.90.69, 0404.10.26, 0404.10.28, 0404.10.32, 0404.10.34, 0404.10.36, 0404.10.38, 0404.10.48, 0404.10.72, 0404.10.74, 0404.10.76, 0404.10.78, 0404.10.82, 0404.10.84, 0404.90.81, 0404.90.83, e 0404.90.89.

2 Apresentação de duas tarifas alternativamente. Das duas combinações tomou-se aquela que produziu a maior tarifa total, conforme a regra 7, página 12 do documento .pdf da Taric.

Ex.: 1704.90.30: 9,1 + 45,1 Euro/100 k/net MAX 18,9 + 16,5 Euro/100 k/net

3 Nos casos de acréscimo devido à presença de componente agrícola (E/A), açúcar (S/Z) ou farinha $(\mathrm{F} / \mathrm{M})$, empregou-se o teor de glucose, amido ou proteína conforme a descrição da alínea. Já nos casos omissos, tomou-se o valor médio das alternativas disponíveis.

E/A (acréscimo devido à presença de componente agrícola): 156,35 Euro/100 kg net S/Z (acréscimo devido à presença de açúcar): 38,09 Euro/100 kg net F/M (acréscimo devido à presença de farinha): 17,73 Euro/100 kg net

4 No anexo B dos preços de entrada, tomaram-se os mais altos (tarifa varia inversamente ao preço de entrada).

5 Há muitos casos em que os produtos contabilizavam dupla tarifação específica, já no nível extraquota.

Ex.: 2009.69.11: 40 + 121 Euro/hl + 20,6 Euro/ $100 \mathrm{~kg} / \mathrm{net}$

6 Nos casos exemplificados abaixo, também há duas tarifas possíveis excludentes entre si. Dessas duas tarifas tomou-se a maior, conforme a nota 7 da página 12 do .pdf. da Taric. Ex.: 2105.00.10: 8,6 + 20,2 Euro/100 kg net MAX 19,4 + 9,4 Euro/100 kg net 
Ex.:2106.90.20: 17,3 MIN 1 Euro \% vol/hl (1 alc. 100\%).

7 As seguintes tarifas experimentaram três tarifas sob o regime de entry price (uma ad valorem e duas específicas): 2204.30.92, 2204.30.94, 2204.30.96, e 2204.30.98.

8 Em 2205.10.90: 0,9 Euro/\% vol/hl + 6,4 Euro/hl obedeceu-se à nota 7, página 12 do .pdf. da Taric, conforme exemplificado abaixo.

Ex.: conteúdo de álcool por volume $=40 \% . \mathrm{T}=0,9 * 40+6,4=42,4 \mathrm{Euro} / \mathrm{hl}$.

9 2206.00.10: 1,3 Euro/\% vol/hl MIN 7,2 Euro/hl. Em casos assim, vale das duas tarifas a maior. Ex.: conteúdo de álcool por volume $=50 \% . \mathrm{T}=1,3 * 50$ ou $\mathrm{T}=7,2 \mathrm{Euro} / \mathrm{hl}$. Vale a maior: $\mathrm{T}=65 \mathrm{Euro} / \mathrm{hl}$.

10 2208.40.11: 0,6 Euro/\% vol/hl + 3,2 Euro/hl (1. alc. 100\%, litro de álcool puro). Está explícito que se trata de uma soma. $\mathrm{T}=\mathrm{t}_{1}(0,6 \mathrm{Euro} / \% \mathrm{vol} / \mathrm{hl})+\mathrm{t}_{2}(3,2 \mathrm{Euro} / \mathrm{hl})$. Idem para 2208.40 .39 e 2208.90 .91$.

11 Em 2401.10.10: 18,4 MIN 22 Euro MAX 24 Euro/100 kg/net tomou-se a tarifa ad valorem + a MAX específica. Idem até 2401.30.00, na seqüência.

12 Em 2402.10.00, 2402.20.10, 2402.20.90, e 2204.30.10 considerou-se a tarifa \%, não as 1.000 unidades. O texto da Taric deixa a entender que é \%.

13 Para 3505.20.10 (8,3 + 4,5 Euro/100 kg/net MAX 11,5) considerou-se das duas tarifas a maior, mantendo a regra 7 da página 12 da Taric. Idem para 3505.20.30, 3505.20.50, 3505.20.90, 3809.10.10, 3809.10.30, 3809.10.50, 3809.10.90.

14 Nos casos em que se apresentava a expressão "\% vol/hl” como segunda tarifa expecífica, supôs-se conteúdo de álcool por volume $=50 \%$.

$152106.90 .10(8,3+78,3$ Euro/100 kg/net) exibiu tarifa autônoma, mas ela era superior à tarifa do corpo do texto. Assim, considerou-se esta última.

16 Nos casos abaixo, também tomou-se das duas tarifas a maior.

Ex.: 6,2 + 27,1 Euro/100 kg/net MAX 17,9 ou similar em 1704.10.11, 1704.10.19, 1704.10.91 e 1704.10.99. 


\section{ANEXO B}

Tabela 32. As reformas de 1992 e 2000 da Política Agrícola Comum.

\begin{tabular}{|c|c|c|}
\hline Produto & Reforma MacSharry (1992) & Agenda 2000 \\
\hline $\begin{array}{l}\text { Cereais } \\
\text { (Geral) }\end{array}$ & $\begin{array}{l}\text { Preço de intervenção de } € 119,19 / \mathrm{t} \text {. } \\
\text { Introdução do "set-aside": obrigação de } \\
\text { não cultivar } 10 \% \text { da área arável da } \\
\text { propriedade } \\
\text { Decoupling - introdução de pagamentos } \\
\text { diretos baseados na área cultivada e de } \\
\text { pagamentos compensatórios pela renda } \\
\text { perdida sujeitos ao cumprimento do set- } \\
\text { aside }\end{array}$ & $\begin{array}{l}\text { Preço de intervenção de } € 101,31 / \mathrm{t} \text {. } \\
\text { mais pagamento direto de } € 63 / \mathrm{t} \text {. } \\
\text { multiplicado pela produtividade física } \\
\text { de referência. } \\
\text { Incrementos mensais aplicados em } \\
\text { sete etapas, todas adicionando } € \\
0,93 / \text { t. ao preço de intervenção } \\
\text { Medidas horizontais. }\end{array}$ \\
\hline Centeio & Intervenção conforme o nível geral de in & ervenção para cereais \\
\hline Trigo duro & $\begin{array}{l}\text { Introdução dos conceitos de decoupling } \\
\text { e de set-aside }\end{array}$ & $\begin{array}{l}\text { Pagamentos suplementares } \\
\text { específicos: } \\
\text { - } € 344,5 / \text { ha em áreas } \\
\text { "tradicionais" } \\
\text { - } € 138,9 / \text { ha em áreas } \\
\text { "estabelecidas" }\end{array}$ \\
\hline Oleaginosas & $\begin{array}{l}\text { Sujeita às mesmas regras gerais válidas } \\
\text { para cereais: } \\
\text { - } \quad \text { pagamentos compensatórios } € \\
433.5 / \text { ha }\end{array}$ & $\begin{array}{l}\text { Alinhamento dos pagamentos por } \\
\text { área cultivada para oleaginosas e } \\
\text { cereais ( } € 63 / \text { t.) }\end{array}$ \\
\hline & - $\quad$ Set-aside: $10 \%$ & \\
\hline Proteaginosas & $\begin{array}{l}\text { Sujeita às mesmas regras gerais válidas } \\
\text { para cereais: } \\
\text { - } \quad \text { pagamentos compensatórios por } \\
\text { hectare de } € 78,49 / \mathrm{t} \text {. } \\
\text { - Set-aside: } 10 \%\end{array}$ & $\begin{array}{l}\text { Pagamento suplementar de } € 9,5 / \mathrm{t} \text {. } \\
\text { multiplicado pela produtividade física } \\
\text { de referência (total de } € 72,5 / \mathrm{t} \text {. }=63+ \\
9,5 \text { ) }\end{array}$ \\
\hline Arroz & $\begin{array}{l}\text { Introdução do conceito de decoupling e } \\
\text { set-aside }\end{array}$ & $\begin{array}{l}\text { Preço de intervenção de } € 298,35 / \text { t. } \\
\text { Pagamento direto de } € 52,65 / \text { t., pago } \\
\text { por hectare, dentro da Área Máxima } \\
\text { Garantida (AMG) }\end{array}$ \\
\hline
\end{tabular}


Tabela 32. As reformas de 1992 e 2000 da Política Agrícola Comum.

\begin{tabular}{|c|c|c|}
\hline Produto & Reforma MacSharry (1992) & Agenda 2000 \\
\hline Forragens secas & $\begin{array}{l}\text { Introdução do conceito de decoupling e } \\
\text { set-aside }\end{array}$ & $\begin{array}{l}\text { Pagamentos diretos: } \\
€ 68,83 / \text { t. para forragens desidratadas } \\
€ 38,64 / \text { t. para forragens secas ao sol }\end{array}$ \\
\hline Nozes & $\begin{array}{l}\text { Planos plurianuais de melhoria de qualid } \\
\text { associações de produtores } \\
\text { Medidas específicas revogadas em 1996, } \\
\text { período de } 10 \text {-anos com o último expiran } \\
\text { Nenhuma medida de suporte específico e } \\
\text { de melhoria }\end{array}$ & $\begin{array}{l}\text { de e marketing, coordenados pelas } \\
\text { porem planos podem continuar pelo } \\
\text { lo em } 2006 / 07 \\
\text { iste atualmente após o final dos planos }\end{array}$ \\
\hline Carne Bovina & $\begin{array}{l}\text { Preço de intervenção de } € 3.447 / \mathrm{t} \text { sendo } \\
\text { que o preço básico é } 80 \% \text { desse valor } \\
(€ 2.780 / \mathrm{t})\end{array}$ & $\begin{array}{l}\text { Redução do preço básico de } \\
\text { intervenção para } € 2.224 / \text { t. Compra } \\
\text { de carne de terneiros por um preço } \\
\text { mínimo de intervenção de } € 1.560 / t \text {. } \\
\text { Pagamento por unidade animal de } \\
€ 150 \text { para novilhos, } € 210 \text { para touros } \\
\text { e } € 200 \text { para vacas. } \\
\text { Prêmio adicional de abate de } € 80 \text { para } \\
\text { animais velhos e } € 50 \text { para bezerros. } \\
\text { Critério de elegibilidade: até } 1,9 \\
\text { UA/ha, com limite de } 90 \text { UA. } \\
\text { Prêmio de "extensificação" de } € 100 \\
\text { para lotação de até } 1,4 \text { UA/ha }\end{array}$ \\
\hline Leite e Derivados & $\begin{array}{l}\text { Regime de quotas (introduzido em } 84 \text { ) } \\
\text { válido até } 2008 \\
\text { Preço de Intervenção: } \\
\text { - } \quad \text { Leite fluido: } € 309,8 / \mathrm{t} \\
\text { - Manteiga: } € 3.282 / \mathrm{t} \\
\text { - } \quad \text { Queijo: } € 2.055,2 / \mathrm{t} \text {. }\end{array}$ & $\begin{array}{l}\text { Redução do preço de intervenção em } \\
15 \% \text { a partir de } 2005 / 06 \text {, por etapas. } \\
\text { Prêmio por vaca em lactação aumenta } \\
\text { de } € 5,75 / \text { t. para } € 17,24 / \text { t. da quota de } \\
2005 / 06 \text { em diante mais. } \\
\text { Aumento global das quotas de } 2,39 \%\end{array}$ \\
\hline
\end{tabular}

Fonte: Jank et al. (2003) 
Tabela 33. Abertura das sazonalidades no regime de preços de entrada da UE.

\begin{tabular}{|c|c|c|c|c|c|}
\hline SH8 & Descrição & Período & $\begin{array}{c}\text { Correlação } \\
\text { pontual }\end{array}$ & Sazonalidades & $\begin{array}{c}\text { Correlação } \\
\text { média }\end{array}$ \\
\hline \multirow[t]{8}{*}{0702.00 .00} & Tomates frescos ou congelados & $01 / 01-31 / 03$ & $-68 \%$ & & \\
\hline & & 01/04-30/04 & $-73 \%$ & & \\
\hline & & $01 / 05-14 / 05$ & $-65 \%$ & & \\
\hline & & $15 / 05-31 / 05$ & $-65 \%$ & & \\
\hline & & 01/06-30/09 & $-61 \%$ & & \\
\hline & & $01 / 10-31 / 10$ & $-63 \%$ & & \\
\hline & & $01 / 11-20 / 12$ & $-63 \%$ & & \\
\hline & & $21 / 12-31 / 12$ & $-64 \%$ & 8 & $-65 \%$ \\
\hline \multirow[t]{7}{*}{0707.00 .05} & Pepinos & 01/01-28/02 & $-61 \%$ & & \\
\hline & & 01/03-30/04 & $-68 \%$ & & \\
\hline & & $01 / 05-15 / 05$ & $-78 \%$ & & \\
\hline & & $16 / 05-30 / 09$ & $-78 \%$ & & \\
\hline & & $01 / 10-31 / 10$ & $-81 \%$ & & \\
\hline & & $01 / 11-10 / 11$ & $-61 \%$ & & \\
\hline & & $11 / 11-31 / 12$ & $-60 \%$ & 7 & $-70 \%$ \\
\hline \multirow[t]{4}{*}{0709.10 .00} & Alcachofra & 01/01-31/05 & $-72 \%$ & & \\
\hline & & 01/06-30/06 & $-68 \%$ & & \\
\hline & & $01 / 07-31 / 10$ & & & \\
\hline & & $01 / 11-31 / 12$ & $-75 \%$ & 4 & $-72 \%$ \\
\hline \multirow[t]{5}{*}{0709.90 .70} & Abobrinha & $01 / 01-31 / 01$ & $-70 \%$ & & \\
\hline & & $01 / 02-31 / 03$ & $-67 \%$ & & \\
\hline & & 01/04-31/05 & $-77 \%$ & & \\
\hline & & 01/06-31/07 & $-67 \%$ & & \\
\hline & & $01 / 08-31 / 12$ & $-70 \%$ & 5 & $-70 \%$ \\
\hline \multirow[t]{7}{*}{0805.10 .10} & Laranja doce (Sanguinea) & $01 / 01-31 / 03$ & $-80 \%$ & & \\
\hline & & 01/04-30/04 & $-80 \%$ & & \\
\hline & & $01 / 05-15 / 05$ & $-80 \%$ & & \\
\hline & & $16 / 05-31 / 05$ & $-80 \%$ & & \\
\hline & & $01 / 06-15 / 10$ & & & \\
\hline & & $16 / 10-30 / 11$ & & & \\
\hline & & $01 / 12-31 / 12$ & $-80 \%$ & 7 & $-80 \%$ \\
\hline \multirow[t]{7}{*}{0805.10 .30} & Laranja doce (Hamlin) & $01 / 01-31 / 03$ & $-80 \%$ & & \\
\hline & & 01/04-30/04 & $-80 \%$ & & \\
\hline & & $01 / 05-15 / 05$ & $-80 \%$ & & \\
\hline & & $16 / 05-31 / 05$ & $-80 \%$ & & \\
\hline & & $01 / 06-15 / 10$ & & & \\
\hline & & $16 / 10-30 / 11$ & & & \\
\hline & & $01 / 12-31 / 12$ & $-80 \%$ & 7 & $-80 \%$ \\
\hline
\end{tabular}


Tabela 33. Abertura das sazonalidades no regime de preços de entrada da UE.

\begin{tabular}{|c|c|c|c|c|c|}
\hline SH8 & Descrição & Período & $\begin{array}{c}\text { Correlação } \\
\text { pontual }\end{array}$ & Sazonalidades & $\begin{array}{l}\text { Correlação } \\
\text { média }\end{array}$ \\
\hline \multirow[t]{7}{*}{0805.10 .50} & Laranja doce (outras) & $01 / 01-31 / 03$ & $-80 \%$ & & \\
\hline & & 01/04-30/04 & $-80 \%$ & & \\
\hline & & $01 / 05-15 / 05$ & $-76 \%$ & & \\
\hline & & $16 / 05-31 / 05$ & $-76 \%$ & & \\
\hline & & 01/06-15/10 & & & \\
\hline & & $16 / 10-30 / 11$ & & & \\
\hline & & $01 / 12-31 / 12$ & $-80 \%$ & 7 & $-78 \%$ \\
\hline \multirow[t]{3}{*}{0805.20 .10} & Clementina (híbrido de laranja) & 01/01-28/02 & $-86 \%$ & & \\
\hline & & $01 / 03-31 / 10$ & & & \\
\hline & & 01/11-31/12 & $-86 \%$ & 3 & $-86 \%$ \\
\hline \multirow[t]{3}{*}{0805.20 .30} & Tangerina (Satsuma/Monreale) & 01/01-28/02 & $-67 \%$ & & \\
\hline & & $01 / 03-31 / 10$ & & & \\
\hline & & $01 / 11-31 / 12$ & $-67 \%$ & 3 & $-67 \%$ \\
\hline \multirow[t]{3}{*}{0805.20 .50} & Tangerina (Mandarin) & 01/01-28/02 & $-67 \%$ & & \\
\hline & & $01 / 03-31 / 10$ & & & \\
\hline & & $01 / 11-31 / 12$ & $-67 \%$ & 3 & $-67 \%$ \\
\hline \multirow[t]{3}{*}{0805.20 .70} & Tangerina & 01/01-28/02 & $-67 \%$ & & \\
\hline & & $01 / 03-31 / 10$ & & & \\
\hline & & $01 / 11-31 / 12$ & $-67 \%$ & 3 & $-67 \%$ \\
\hline \multirow[t]{3}{*}{0805.20 .90} & Tangerina (outras) & 01/01-28/02 & $-67 \%$ & & \\
\hline & & $01 / 03-31 / 10$ & & & \\
\hline & & $01 / 11-31 / 12$ & $-67 \%$ & 3 & $-67 \%$ \\
\hline \multirow[t]{6}{*}{0805.50 .10} & Limão & 01/01-30/04 & $-61 \%$ & & \\
\hline & & $01 / 05-31 / 05$ & $-71 \%$ & & \\
\hline & & 01/06-31/07 & $-76 \%$ & & \\
\hline & & 01/08-15/08 & $-72 \%$ & & \\
\hline & & $16 / 08-31 / 10$ & $-64 \%$ & & \\
\hline & & $01 / 11-31 / 12$ & $-61 \%$ & 6 & $-68 \%$ \\
\hline \multirow[t]{5}{*}{0806.10 .10} & Uvas de mesa & 01/01-14/07 & & & \\
\hline & & $15 / 07-20 / 07$ & & & \\
\hline & & $21 / 07-31 / 10$ & $-100 \%$ & & \\
\hline & & $01 / 11-20 / 11$ & $-80 \%$ & & \\
\hline & & $21 / 11-31 / 12$ & & 5 & $-90 \%$ \\
\hline \multirow[t]{2}{*}{0808.10 .20} & Uvas (Golden Delicious) & 01/01-14/02 & $-64 \%$ & & \\
\hline & & $15 / 02-31 / 03$ & $-71 \%$ & & \\
\hline
\end{tabular}


Tabela 33. Abertura das sazonalidades no regime de preços de entrada da UE.

\begin{tabular}{|c|c|c|c|c|c|}
\hline SH8 & Descrição & Período & $\begin{array}{c}\text { Correlação } \\
\text { pontual }\end{array}$ & Sazonalidades & $\begin{array}{c}\text { Correlação } \\
\text { média }\end{array}$ \\
\hline & & 01/04-30/06 & $-75 \%$ & & \\
\hline & & $01 / 07-15 / 07$ & $-67 \%$ & & \\
\hline & & $16 / 07-31 / 07$ & $-61 \%$ & & \\
\hline & & $01 / 08-31 / 12$ & $-63 \%$ & 6 & $-67 \%$ \\
\hline \multirow[t]{6}{*}{0808.10 .50} & Uvas (Granny Smith) & 01/01-14/02 & $-64 \%$ & & \\
\hline & & $15 / 02-31 / 03$ & $-71 \%$ & & \\
\hline & & 01/04-30/06 & $-75 \%$ & & \\
\hline & & 01/07-15/07 & $-67 \%$ & & \\
\hline & & $16 / 07-31 / 07$ & $-61 \%$ & & \\
\hline & & $01 / 08-31 / 12$ & $-63 \%$ & 6 & $-67 \%$ \\
\hline \multirow[t]{6}{*}{0808.10 .90} & Uvas (outras) & 01/01-14/02 & $-64 \%$ & & \\
\hline & & $15 / 02-31 / 03$ & $-71 \%$ & & \\
\hline & & 01/04-30/06 & $-75 \%$ & & \\
\hline & & 01/07-15/07 & $-69 \%$ & & \\
\hline & & $16 / 07-31 / 07$ & $-63 \%$ & & \\
\hline & & $01 / 08-31 / 12$ & $-63 \%$ & 6 & $-68 \%$ \\
\hline 0808.20.10 & Pêras (Perry) & 01/08-31/12 & & 1 & \\
\hline \multirow[t]{8}{*}{0808.20 .50} & Pêras (outras que não Perry) & 01/01-31/01 & $-63 \%$ & & \\
\hline & & $01 / 02-31 / 03$ & $-63 \%$ & & \\
\hline & & 01/04-30/04 & $-72 \%$ & & \\
\hline & & 01/05-30/06 & & & \\
\hline & & $01 / 07-15 / 07$ & $-70 \%$ & & \\
\hline & & $16 / 07-31 / 07$ & $-62 \%$ & & \\
\hline & & 01/08-31/10 & $-60 \%$ & & \\
\hline & & $01 / 11-31 / 12$ & $-63 \%$ & 8 & $-65 \%$ \\
\hline \multirow[t]{5}{*}{0809.10 .00} & Damasco & 01/01-31/05 & & & \\
\hline & & 01/06-20/06 & $-79 \%$ & & \\
\hline & & 21/06-30/06 & $-74 \%$ & & \\
\hline & & 01/07-31/07 & $-71 \%$ & & \\
\hline & & 01/08-31/12 & & 5 & $-75 \%$ \\
\hline \multirow[t]{7}{*}{ 0809.20.05 } & Cerejas amargas & 01/01-30/04 & & & \\
\hline & & 01/05-20/05 & & & \\
\hline & & $21 / 05-31 / 05$ & $-98 \%$ & & \\
\hline & & 01/06-15/07 & $-99 \%$ & & \\
\hline & & $16 / 07-31 / 07$ & $-99 \%$ & & \\
\hline & & 01/08-10/08 & $-100 \%$ & & \\
\hline & & $11 / 08-31 / 12$ & & 7 & $-99 \%$ \\
\hline
\end{tabular}


Tabela 33. Abertura das sazonalidades no regime de preços de entrada da UE.

\begin{tabular}{|c|c|c|c|c|c|}
\hline SH8 & Descrição & Período & $\begin{array}{c}\text { Correlação } \\
\text { pontual }\end{array}$ & Sazonalidades & $\begin{array}{c}\text { Correlação } \\
\text { média }\end{array}$ \\
\hline \multirow[t]{8}{*}{0809.20 .95} & Cerejas (outras) & 01/01-30/04 & & & \\
\hline & & 01/05-20/05 & & & \\
\hline & & $21 / 05-31 / 05$ & $-83 \%$ & & \\
\hline & & 01/06-15/06 & $-78 \%$ & & \\
\hline & & $16 / 06-15 / 07$ & $-78 \%$ & & \\
\hline & & $16 / 07-31 / 07$ & $-78 \%$ & & \\
\hline & & 01/08-10/08 & $-71 \%$ & & \\
\hline & & $11 / 08-31 / 12$ & & 8 & $-78 \%$ \\
\hline \multirow[t]{5}{*}{0809.30 .10} & Pêssegos & 01/01-10/06 & & & \\
\hline & & $11 / 06-20 / 06$ & $-89 \%$ & & \\
\hline & & $21 / 06-31 / 07$ & $-100 \%$ & & \\
\hline & & 01/08-30/09 & $-78 \%$ & & \\
\hline & & 01/10-31/12 & & 5 & $-89 \%$ \\
\hline \multirow[t]{5}{*}{0809.30 .90} & Nectarinas (outras) & 01/01-10/06 & & & \\
\hline & & $11 / 06-20 / 06$ & $-100 \%$ & & \\
\hline & & $21 / 06-31 / 07$ & $-85 \%$ & & \\
\hline & & 01/08-30/09 & $-74 \%$ & & \\
\hline & & $01 / 10-31 / 12$ & & 5 & $-86 \%$ \\
\hline \multirow[t]{4}{*}{0809.40 .05} & Ameixa & 01/01-10/06 & & & \\
\hline & & $11 / 06-30 / 06$ & $-100 \%$ & & \\
\hline & & 01/07-30/09 & $-89 \%$ & & \\
\hline & & $01 / 10-31 / 12$ & & 4 & $-95 \%$ \\
\hline 2009.61.10 & Suco de uva ${ }^{1}$ & & $-60 \%$ & 1 & $-60 \%$ \\
\hline 2009.69.19 & Suco de uva (outro) & & $-60 \%$ & 1 & $-60 \%$ \\
\hline 2009.69 .51 & Suco de uva conc. ${ }^{1}$ & & $-100 \%$ & 1 & $-100 \%$ \\
\hline 2009.69.59 & Suco de uva conc. (outro) & & $-65 \%$ & 1 & $-65 \%$ \\
\hline 2204.30 .92 & Suco de uva não fermentado conc. & & $-59 \%$ & 1 & $-59 \%$ \\
\hline 2204.30 .94 & Suco de uva não fermentado conc. (outro) & & $-60 \%$ & 1 & $-60 \%$ \\
\hline 2204.30 .96 & Suco de uva não fermentado conc. & & $-61 \%$ & 1 & $-61 \%$ \\
\hline 2204.30 .98 & Suco de uva não fermentado conc. (outro) & & $-59 \%$ & 1 & $-59 \%$ \\
\hline
\end{tabular}

Referem-se a valor acima de 18 euros $/ 100 \mathrm{~kg}$ de peso líquido

Notas: no caso dos códigos 2009.61 e 2009.69, a diferenciação dos produtos se dá pelo teor de açúcar por volume do produto a uma dada temperatura;

os quatro códigos do subgrupo 2204.30 são diferenciados com base na densidade da bebida aos $20^{\circ} \mathrm{C}$ e no teor alcoólico por volume. 
Tabela 34. Itens excluídos da análise com os preços Brasileiros de exportação.

\begin{tabular}{cl}
\hline SH8 & \\
\hline 0104.20 .90 & Cabra, bode (animal vivo) \\
0204.10 .00 & Carcaças e meias carcação \\
0405.20 .10 & Pastas lácteas contendo diferentes teores de gordura. \\
0405.20 .30 & Pastas lácteas contendo diferentes teores de gordura. \\
0405.20 .90 & Pastas lácteas contendo diferentes teores de gordura. \\
0809.10 .00 & Damasco \\
0809.20 .05 & Cereja azeda \\
0809.20 .95 & Outras cerejas \\
0809.30 .10 & Pêssegos e nectarinas \\
0809.30 .90 & Outros pêssegos \\
1003.00 .10 & Semente de cevada \\
1003.00 .90 & Cevada (outras) \\
1107.20 .00 & Malte de trigo torrado \\
1109.00 .00 & Glúten de trigo, seco ou não \\
1212.91 .20 & Açúcar à base de beterraba \\
1212.91 .80 & Açúcar à base de beterraba \\
1902.40 .10 & Sêmola de trigo não preparada \\
1902.40 .90 & Sêmola de trigo (outra) \\
1904.30 .00 & Trigo búlgaro \\
1905.10 .00 & Pão crocante \\
2008.50 .19 & Preparação alimentícia contendo essência da fruta damasco \\
2008.50 .51 & Prep. alimentícias c/ essência de damasco e mais que 15\% de açúcar por peso. \\
2303.10 .11 & Resíduos da produção de amido de milho, c/ mais que 40\% de proteína. \\
2306.90 .19 & Resíduos da extração de óleo de oliva, com mais do que 3\% de óleo de oliva. \\
2307.00 .19 & Resíduos outros da produção de vinho (wine less) \\
\hline
\end{tabular}




\section{REFERÊNCIAS BIBLIOGRÁFICAS}

ABBOTT, P.C. Tariff rate quotas: failed market access instruments? EUROPEAN ASSOCIATION OF AGRICULTURAL ECONOMISTS SEMINAR, 77., Helsinki, 2001. International agricultural trade: old and new challenges. Helsinki: EAAE, 2001. 25p.

ABRAMOVAY, R. Dilemas da União Européia na reforma da Política Agrícola Comum. São Paulo, 1999. 131p. Tese (Livre-Docência) - Faculdade de Economia, Administração e Contabilidade, Universidade de São Paulo.

AUSTRALIAN BUREAU OF AGRICULTURAL AND RESOURCE ECONOMICS (ABARE). US and EU Agricultural support: who does it benefit? Canberra, 2000. 6p.

BALDWIN, R.E. Political economy of U.S. import policy. Cambridge: MIT Press, 1985. 114p.

BORRELL, B.; HUBBARD, L. Global economic effects of the EU common agricultural policy. Oxford: Institute of Economic Affairs / Blackwell Publishers, 2000. 9p. (Institute of Economic Affairs, Reforming the CAP Series)

BOUËT, A. La mesure des protections commerciales nationales. Paris: Centre $d$ 'Études Prospectives et d'Informations Internationales (CEPII), 2000. 54p.

BOUËT, A. A bilateral and disaggregated measurement of agricultural market access in the European Union and in Mercosur. Paris: Centre d'Analyse Économique et de Traitement dês données économiques (CATT) / Centre d’Études Prospectives et d'Informations Internationales (CEPII), 2003. 31p. 
BOUËT, A.; FONTAGNÉ, L.; MIMOUNI, M. et al. A bilateral and disaggregated measure of market access. Paris: Centre d'Études Prospectives et d'Informations Internationales (CEPII), 2001. 54p.

BOUWEN, P. A comparative study of business lobbying in the EU Parliament: the European Commission and the Council of Ministers. Köln: Max-Planck-Institut für Gesellschaftsforschung Paulstrass (MPIfG), 2002. 32p.

BRASIL. Ministério do Desenvolvimento, Indústria e Comércio Exterior. Barreiras externas às exportações brasileiras 1999. Brasília, 1999. 280p.

BRASIL. Ministério do Desenvolvimento, Indústria e Comércio Exterior. Barreiras externas às exportações brasileiras 2001. Brasília, 2001. 86p.

BRASIL. Ministério do Desenvolvimento, Indústria e Comércio Exterior. As negociações Mercosul - União Européia. Brasília, 2003. http://www.mdic.gov.br/comext/Deint/ infoMercosulUE.htm (26 dez. 2003)

BUARQUE, S.C. Metodologia e técnicas de construção de cenários globais e regionais. Brasília: Instituto de Pesquisa Econômica Aplicada (IPEA), 2003. 75p. (Texto para Discussão, 939)

BUREAU, J.C. Enlargement and reform of the EU agricultural policy: impacts on the western hemisphere countries. Washington, 2002. 42p. (Final report)

BUREAU, J.C.; SALVATICI, L. Agricultural trade restrictiveness in the European Union and the United States. Iowa: Iowa State University, 2001. 29p. (CARD Working Paper, 01WP277)

BUREAU, J.C.; FULPONI, L.; SALVATICI, S. Comparing EU and US trade liberalisation on the Uruguay round agreement. European Review of Agricultural Economics, v.27, n.3, p.259-280, 2000. 
BUSSAB, W.O.; MORETTIN, P. Estatística básica. São Paulo: Atlas, 1987. 322p.

BUSSAB, W.O. Análise de variância e de regressão. São Paulo: Atlas, 1988. 148p.

CASTILHO, M.R. O sistema de preferências comerciais da União Européia. Brasília: Instituto de Pesquisa Econômica Aplicada (IPEA), 2000. 67p. (Texto para Discussão, 742)

CIOFFI, A.; DELL'AQUILA, C. The effects of trade policies for fresh fruits and vegetables of the European Union. Napoli: Università di Napoli "Federico II", 2003. 20p.

COMISSÃO EUROPÉIA. L'agriculture dans l'Union Européenne: informations statistiques et economiques 2000. http://europa.eu.int/comm/ agriculture/agrista/2000/table_fr/index.htm (08 dez. 2001)

COMISSÃO EUROPÉIA. The agricultural situation in the European Union: 1999 report. Bruxelas, 2001a. 72p.

COMISSÃO EUROPÉIA. Prospects for agricultural markets 2002-2009: up date for EU markets. Bruxelas, 2002. 14p.

COMISSÃO EUROPÉIA. Office for official publications of the European Communities. Consolidated TEXT (CONSLEG: 1994R3223 - 04/11/2002). Bruxelas, 2002a. 8p.

COMISSÃO EUROPÉIA. Bilateral trade relations. http://europa.eu.int/ comm/trade/issues/bilateral/countries/brazil/index_en.htm (09 Feb. 2004)

CORDEN, W.M. Trade policy and economic welfare. Oxford: Clarendon Press, 1974. $423 \mathrm{p}$.

CUNHA FILHO, J.H. As quotas tarifárias e o acesso dos produtos agroindustriais Brasileiros ao mercado internacional. Piracicaba, 2004. 159p. Dissertação (M.S.) Escola Superior de Agricultura "Luiz de Queiroz”, Universidade de São Paulo. 
DEARDORFF, A. Glossary of international economics. http://wwwpersonal.umich.edu/ alandear/glossary/ (26 Dec. 2003)

ELLIOTT, M.; HEATH, A. The failure of CAP reform: a public choice analysis. Oxford: Institute of Economic Affairs; Londres: Blackwell Publishers, 2000. 7p. (Institute of Economic Affairs, Reforming the CAP Series)

FOOD AND AGRICULTURAL POLICY RESEARCH INSTITUTE (FAPRI). The Doha round of the World Trade Organization: appraising further liberalization of agricultural markets. Iowa: Iowa State University, Food and Agricultural Policy Research Institute, 2002. 130p. (Working Paper, 02-October)

FOREIGN TRADE AND INFORMATION SERVICE (FTIS). Agreement establishing the World Trade Organization: the Uruguay round final act. http://www.sice.oas.org/trade/ ur_round/URTOC.asp (12 Dec. 2002)

GÁCS, J.; WYZAN, M. The European Union and the rest of the world: complements or substitutes for Central and Eastern Europe? Luxemburgo: International Institute for Applied Systems Analysis, 1998. 73p.

GALLEZOT, J. Accès au marché agricole et agro-alimentaire de l'Union européenne: le point de vue du négociateur à l'OMC et celui du douanier. Economie Rurale, n.267, p.43-54, 2002.

GIBSON, P.; BOHMAN, M.; WAINIO, J. et al. Profiles of tariffs in global agricultural markets $\boldsymbol{A E R \_ 7 9 6 . ~ W a s h i n g t o n : ~ U n i t e d ~ S t a t e s ~ D e p a r t m e n t ~ o f ~}$ Agriculture (USDA), 2001. 44p.

GRETHE, H.; TANGERMANN, S. The EU import regime for fruit fresh and vegetables after implementation of the results of the Uruguay round. Göttingen: Institut of Agricultural Economics, 1998. 41p. (Diskussionsbeitrag, 9901) 
HOEKMAN, B.; FRANCIS, N.; OLARREAGA, M. Tariff peaks in the quad and least developed country exports. Londres: Centre for Economic Policy Research, 2001. 55p.

HOWARTH, R. The CAP: history and attempts at reform. Oxford: Institute of Economic Affairs; Londres: Blackwell Publishers, 2000. 7p. (Institute of Economic Affairs, Reforming the CAP Series)

HUDEC, R.E. Tiger, tiger in the house: a critical appraisal of the case against discriminatory trade measures. In: JACKSON, J.H.; SYKES, A.O. (Ed.). Implementing the Uruguay Round. Oxford: Clarendon Press, 1997. p.167-212.

INTERNATIONAL AGRICULTURAL TRADE RESEARCH CONSORTIUM (IATRC). Issues in reforming tariff-rate import quotas in the agreement on agriculture in the WTO. St. Paul, 2001. 186p. (Commissioned paper, 13)

INTERNATIONAL MONETARY FUND (IMF); WORLD BANK (WB). Market access for developing countries' exports. Washington, 2001. 61p.

JANK, M.S.; NASSAR, A.M.; FREITAS, R.E. et al. A política agrícola comum da União Européia e seu impacto nas negociações internacionais. Brasília: Ministério das Relações Exteriores, 2002. 147p.

JANK, M.S.; BRACALE, G.; ARAÚJO, L.R. A reforma da Política Agrícola Comum da União Européia: análise dos impactos na $\mathrm{OMC}$ sob a ótica dos interesses comerciais Brasileiros. Comércio Exterior em Perspectiva, v.12, n.10, p.6-9, jul. 2003.

KAEMPFER, W.H.; TOWER, E.; WILLETT, T.D. Trade protectionism. In: ROWLEY, C.K. (Ed.). For the encyclopedia of public choice. Durham: Duke University, 2002. 20p. 
KEELER, J.T.S. Agricultural power in the European Community explaining the fate of CAP and GATT negotiations. Comparative Politics, v.28, n.1, p.127-149, 1996.

KRUEGER, A.O. The political economy of the rent seeking society. American Economic Review, v.64, n.3, p.291-303, 1974.

KRUGMAN, P.R.; OBSTFELD, M. International economics: theory and policy. New York: Harper Collins, 1994. 795p.

LAIRD, S. Multilateral approaches to market access negotiations. Genebra: World Trade Organization, 1998. 23p. (Staff Working Paper, TPRD-98-02)

LIMA, A.C.P.; MAGALHÃES, M.N. Noções de probabilidade e estatística. São Paulo: Edusp, 2002. 392p.

MARSCH, J.S.; TARDITI, S. Cultivating a crisis: the global impact of the Common Agricultural Policy. Weybridge: Consumers International and European Research into Consumer Affairs, 2003. 95p.

MENDES, C.C. Aspectos regionais do comércio de bens entre o Brasil e a União Européia. Brasília: Instituto de Pesquisa Econômica Aplicada (IPEA), 2000. 37p. (Texto para Discussão, 705)

MICHALOPOULOS, C. Trade policy and market access issues for developing countries: implications for the millenium round. Washington: World Bank, 1999. $88 \mathrm{p}$.

MITRA, D. Endogenous lobby formation and endogenous protection: a long run model of trade policy determination. American Economic Review, v.89, n.5, p.1116-34, 1999.

OFFICIAL JOURNAL OF THE EUROPEAN COMMUNITIES (OJEC). Common agricultural policy: table of contents. Bruxelas: Official Journal of the European Communities, 1998. 20p. 
ORGANIZATION FOR ECONOMIC COOPERATION AND DEVELOPMENT (OECD). Producer and consumer support estimates, OECD Database 19862002. $2003 . \quad$ Paris, http://www.oecd.org/document/23/ 0,2340,en_2825_494504_4348119_1_1_1_1,00.html (26 Dec. 2003)

RIJSWICK, C.W.J.V.; SILVIS, H.J. Alternative instruments for agricultural support: a survey of measures applied by competitors of the EU. The Hague: Agricultural Economics Research Institute, 2000. 114p.

ROSA, J.G. Grande sertão: veredas. Rio de Janeiro: Nova Fronteira, 2001. 624p.

SKULLY, D.W. Economics of tariff-rate quota administration. Washington: United States Departament of Agriculture (USDA), Market and Trade Division, Economic Research Service, 2001. 23p. (Technical Bulletin, 1893)

STOECKEL, A. A look at the political economy of the agricultural reform: solving the problem. Kingston: Center for International Economics, 2000. 59p. (RIRDC Publication, 00/124)

STOUT, J.; LEETMAA, S.; NORMILE, M.A. Evaluating EU agricultural policy reform using the EU WTO model. Washington: United States Departament of Agriculture (USDA), Economic Research Service, 2002. 15p.

THORSTENSEN, V. OMC: as regras do comércio internacional e a rodada do milênio. São Paulo: Aduaneiras. 406p.

UK FOOD GROUP (UKFG). CAP: how the CAP operates, the key commodities, competitors and markets for the European Union. London, 2002a. 40p.

UK FOOD GROUP (UKFG). The common agricultural policy: options for reform and their potential impact. London, 2002b. 24p. 
UNITED STATES DEPARTAMENT OF AGRICULTURE (USDA). TRQ's have little impact on EU market access, while CEEs may benefit. Washington: Economic Research Service, 1998. 10p. (Europe: situation and outlook series)

UNITED STATES DEPARTAMENT OF AGRICULTURE (USDA). EU preferential trading agreements: heightened competition for the U.S. Washington: Economic Research Service, 2001. 20p. (World Agriculture \& Trade Series)

UNITED STATES DEPARTAMENT OF AGRICULTURE (USDA). The U.S. WTO $\begin{array}{lll}\text { agriculture } & \text { proposal. Washington, } & \end{array}$ http://www.fas.usda.gov/itp/wto/proposal.htm (12 Dec. 2002)

WORLD TRADE ORGANIZATION (WTO). European Communities-regime for the importation, sale and distribution of Bananas: complaint by Ecuador. Genebra, 1997. 402p. (Report by the panel)

WORLD TRADE ORGANIZATION (WTO). Trade policy reviews: first press release, secretariat and government summaries. Genebra, 2000. http://www.wto.org/wto/english/ tratop_e/tpr_e/tp137_e.htm (07 July 2002)

WORLD TRADE ORGANIZATION (WTO). Tariffication and tariff reductions. Genebra, 2002a. http://www.wto.org/english/thewto_e/whatis_e/eol/e/wto01/ wto1_45.htm\#note1 (20 Feb. 2004)

WORLD TRADE ORGANIZATION (WTO). World trade policy: European Union (report by the secretariat). Genebra, 2002b. 139p.

WORLD TRADE ORGANIZATION (WTO). Statistics: international trade statistics 2003: trade by sector. Genebra, 2004. http://www.wto.org/english/res_e/ statis_e/its2003_e/ its03_bysector_e.htm (12 Dec. 2002) 